\title{
Medenî Usûl Hukukunda Hükümden Sonra Feragat ve Davanın Feragat Sebebiyle Sona Erdiğini Ortaya Koyacak Olan Merci: 7251 Sayılı Kanun Değişikliği Kapsamında Değerlendirmeler
}

\author{
The Authority that will Establish the Waiver and Termination of the \\ Lawsuit due to Waiver after the Verdict in Code of Civil Procedure: \\ Considerations within the Scope of Law No. 7251
}

Serpil Işık $k^{*}$ iD

\section{öz}

Davadan feragat, davacının dava dilekçesinde yer alan talep sonucundan kısmen veya tamamen vazgeçmesidir. Kanunda yer alan düzenlemeler uyarınca davadan feragat, hükmün şekli anlamda kesinleşmesine kadar yargılamanın her aşamasında yapılabilecektir. Yargılamanın ilk derece mahkemesinde devam ettiği bir esnada davadan feragat edilebileceği gibi hükmün verilmesinden sonra ve fakat kanun yollarına müracaat edilmesinden önce ya da dosyanın kanun yollarında incelendiği bir aşamada da davadan feragat yoluna gidilebilecektir. Yargılamanın ilk derece mahkemesinde devam ettiği bir sırada davadan feragat edilmesi üzerine, ilk derece mahkemesince davanın feragat sebebiyle sona erdiği ifade edilerek usule ilişkin bir kararla reddedilmesi gerekecektir. Bununla birlikte, ilk derece mahkemesince hüküm verildikten sonra kanun yollarına müracaat süresi içerisindeyken veya hükmün kanun yollarına götürülmesinden sonra davadan feragat edilmesi durumunda hangi merci tarafından ne şekilde bir karar verileceği konusunda, 28.07.2021 tarihli ve 7251 sayılı HMK değişikliğine kadar usul kanunumuzda bir boşluk bulunmaktaydı. Bu sebeple, hükmün verilmesinden sonra kanun yolları süresi içerisinde veya dosyanın kanun yollarında incelendiği bir esnada davacı tarafından davadan feragat edilmesi durumunda müracaat edilecek olan mercii ile bu mercii tarafından verilecek olan karar konusunda Yargıtay’ın yerleşik bir uygulaması söz konusuydu. 01.10.2011 tarihinde 6100 sayılı Hukuk Muhakemeleri Kanunu’nun yürürlüğe girmesinden sonra çıartılan Hukuk Muhakemeleri Kanunu Yönetmeliğìnin 57’nci maddesi ile ilk kez hükmün ilk derece mahkemesince verilmesinden sonra davadan feragat edilmesi konusunda bir düzenleme yapılmıştır. Hukuk Muhakemeleri Kanunu Yönetmeliği’nin yürürlükten kaldırılmasından sonra Bölge Adliye ve Adli Yargı İlk Derece Mahkemeleri ile Cumhuriyet Başsavcılıkları İdari ve Yazı İşleri Hizmetlerinin Yürütülmesine Dair Yönetmeliğin yürürlüğe girmesiyle birlikte bu konuda bir düzenleme (m. 215) getirilmiştir. Getirilen yönetmelik hükümleri ile kanun yollarına müracaat edilmesinden önce davadan feragat beyanının mahkemece inceleneceği ve mahkemenin bu yönde bir "ek karar" vereceği öngörülerek Yargitay uygulamasından farklı ve yeni bir düzenleme kabul edilmiștir. 28.07.2020 tarihinde yürürlüğe giren 7251 sayılı Hukuk Muhakemeleri Kanunu değişikliği sonrasında ise, Kanunda açıkça davadan feragatin yapılma zamanı ve verilecek olan karara ilişkin düzenlemeler getirilmiştir. Böylelikle, Yönetmelik hükümleriyle kabul edilen ve uygulamada var olan durum, Hukuk Muhakemeleri Kanunu’nda da düzenlenerek kanun hükmü olarak öngörülmüştür. Bununla birlikte, yönetmeliklerle öngörülen düzenlemeye kanuni bir temel kazandırılması ve HMK’da ilk defa "ek karar" kavramına yer verilmesi bakımından gerçekleştirilen değişiklik önem arz etmektedir. Çalışmamızda, hükmün ilk derece mahkemesince verilmesinden sonra ve fakat kanun yollarına müracaat edilmesinden önce ya da dosyanın kanun yollarında bulunduğu bir aşamada davadan feragat edilmesi üzerine davanın sona erdiğini tespit eden kararı verecek olan merciinin neresi olduğu Yargıtay kararları, doktrinde ileri sürülen görüşler ve yürürlüğe giren Yönetmelik hükümleri (eski HMK Yönetmeliği m. 57; Yazı İşleri Yönetmeliği m. 215) ile 28.07.2020 tarihinde gerçekleştirilen 7251 sayılı HMK değişikliği çerçevesinde ele alınarak ortaya konulmaya çalışılacaktır.

Anahtar Kelimeler: Medenî Usûl Hukukunda Davadan Feragat, Davadan Feragatin Zamanı, Hükmün Verilmesinden Sonra Davadan Feragat, Kanun Yolları Aşamasında Davadan Feragat, Ek Karar

Araş. Gör. Dr., İstanbul Üniversitesi Hukuk Fakültesi, Medeni Usul ve İcra-İflas Hukuku Anabilim Dalı, ORCID: 0000-0003-4329-1138.

Sorumlu Yazar/Correspondence Author: Serpil Işık

E-posta/E-mail: serpil.isik@istanbul.edu.tr

Geliş Tarihi/Received: $\quad$ 15.08.2021

Kabul Tarihi/Accepted:

10.11 .2021 


\section{ABSTRACT}

Waiver of a lawsuit means the plaintiff to partially or completely withdraw from the claim stated in the petition. According to the regulations in the code, waiver can be given at any stage of the proceeding, until finalization of the form of verdict. While waiver is possible while the proceeding at the court of first instance is ongoing, it is also possible after the verdict is given, yet before applying to legal remedies or during when the lawsuit file is examined for remedies. If the lawsuit is waived while the proceeding at the court of first instance is ongoing, it should be terminated by a procedural decision of the court of first instance stating that the lawsuit was terminated due to waiver. However, there is no provision in our legislation about which decision will be passed, by which authority and in which manner if the withdrawal from the lawsuit is given within the legal time frame to apply to legal remedies after the verdict is given by the court of first instance or after the verdict is appealed through legal remedies. Therefore, there is an established practice of the Court of Cassation on the authority to be applied to and the verdict to be given by this authority if the lawsuit is waived by the plaintiff within the legal time frame for applying to legal remedies after the verdict or while the legal remedies are being examined. Article 57 of the Regulation on Code of Civil Procedure issued after the Code of Civil Procedures No. 6100 came into force on 01.10.2011, introduced for the first time a provision that the lawsuit can be waived after verdict is given by the court of first instance. After the repeal of the Regulation on Code of Civil Procedure, another regulation was introduced with the Regulation on the Regional Courts of Justice and Court of Original Jurisdiction and Chief Public Prosecutor's Office Administrative and Editorial Services (Art. 215). With the provisions of the regulation, a different and new regulation from the practice of the Court of Cassation was adopted by assuming that the court will examine the notice of waiver before applying for legal remedies and will give an "additional verdict" in this respect. After the CCO amendment that entered into force on 28.07 .2020 , provision regarding the case and the decision to be made were clearly introduced in the Law. Thus, the current situation in practice has been regulated in the CCP and brought into law. In our study will try to discuss which authority is to give the verdict that the lawsuit is terminated upon waiver of the lawsuit after verdict is given by the court of first instance but before applying to legal remedies, or while the lawsuit file is being examined according to the legal remedies in terms of the decisions of the Court of Cassation, opinions put forward in the doctrine and the provisions of the Regulations (former HMK Article 57; Regulations Art. 215) and within the framework of the CCP amendment that entered into force on 28.07.2020.

Keywords: Waiver of Lawsuit in Code of Civil Procedure, Time Frame of Waiver from the Lawsuit, Waiver after the Verdict, Waiver from Lawsuit During Legal Remedies, Additional Decision.

\section{GiRiş}

Medenî usûl hukukunda geçerli olan tasarruf ilkesinin doğal bir sonucu olarak davacı, hakkını elde edebilmek için üçüncü bir kişiye karşı açmış olduğu davaya devam edebilir yahut yargılamanın herhangi bir aşmasında davasından vazgeçebilir ${ }^{1}$. Açılmış olan davaya devam etmek istemeyen

1 Yavuz Alangoya, M. Kâmil Yıldırım ve Nevhis Deren-Yıldırım, Medeni Usul Hukuku Esasları (7. Bası, Beta 2009) 422; Murat Atalı, Pekcantez Usul Medeni Usul Hukuku, C. III (15. Bası, On İki Levha 2017) 2012. Tasarruf ilkesine göre, yargılamanın tarafları dava konusu olan hak üzerinde etki ederek serbestçe tasarrufta bulunabilir. Tasarruf ilkesi hakkında ayrıntılı bilgi için bkz.: Baki Kuru, Ramazan Arslan ve Ejder Yılmaz, Medeni Usul Hukuku Ders Kitabı 6100 sayılı HMK'na Göre Yeniden Yazılmış (Tıpkı Basım) (24. Bası, Yetkin 2013) 335; Alangoya, Yıldırım ve Deren-Yıldırım, Esaslar (n 1) 182-183; Nedim Meriç, Medeni Yargılama Hukukunda Tasarruf İlkesi (Hukuk Muhakemeleri Kanunu Çerçevesinde), (Yetkin, 2011) 17 vd.; Güray Erdönmez, Pekcanitez Usul Medeni Usul Hukuku, C. I (15. Bası, On İki Levha, 2017) 783-795; Ali Cem Budak ve Vural Karaaslan, Medeni Usul Hukuku (4. Bas1, Adalet 2020) 82-85; Abdurrahim Karslı, Medeni Muhakeme Hukuku (Yenilenmiş ve Gözden Geçirilmiş 5. Bası, Filiz 2020) 228-231; Murat Atalı, İbrahim Ermenek ve Ersin Erdoğan, Medeni Usul Hukuku Ders Kitabı (3. Bası, Yetkin 2020) 98-102; Ömer Ulukapı, Medenî Usûl Hukuku (3. Bası, Mimoza 2015) 119. 
davacı, böyle bir durumda, "davadan feragat" müessesine müracaat ederek davanın sona ermesini sağlayabilir².

Davadan feragat, 01.10.2011 tarihinde yürürlüğe giren 6100 sayılı Hukuk Muhakemeleri Kanunu’nun ${ }^{3}$ 307 ilâ 312 'nci maddeleri ${ }^{4}$ arasında düzenlenmektedir ${ }^{5}$. Hukuk Muhakemeleri Kanunu’nda yer alan düzenlemeler uyarınca davadan feragat, davacının yargılamayı yürüten mahkemeye yapacağ 1 tek taraflı bir irade beyanıyla gerçekleştirilir ${ }^{6}$. Davadan feragat için karşı tarafın iznine veya mahkemenin onayına ihtiyaç bulunmamaktadır ${ }^{7}$ (HMK m. 309/f. 2). Davadan feragat yargılamanın devam ettiği aşamada davacı tarafından gerçekleştirilebilir ${ }^{8}$.

Davadan feragat, zamansal olarak, hükmün kesinleşmesine kadar yargılamanın her aşamasında yapılabilir9 (HMK m. 310/f. 1). Buna göre, sadece yargllamanın ilk derece mahkemesinde

2 Necip Bilge ve Ergun Önen, Medeni Yargılama Hukuku Dersleri (3. Bs, Sevinç Matbaası 1967) 296; Necip Bilge, Medeni Yargilama Hukuku Dersleri (Sevinç Matbaası 1967) 262; Atalı, Pekcanitez Usul (n 1) 2012; Kuru, Arslan ve Yılmaz, Medeni Usul (n 1) 505. Davadan feragat hakkında ayrıntılı bilgi için bkz.: Leyla Akyol Aslan, Medeni Usul Hukukunda Davadan Feragat (1. Bas1, Yetkin 2011) 65 vd.

3 RG., 4.2.2011, S. 27836.

4 Atalı, Pekcantez Usul (n 1) 2008. Davadan feragat, 1.10.2011 tarihli ve 6100 sayılı Hukuk Muhakemeleri Kanunu'nun “Davaya Son Veren Taraf İşlemeleri” başlıklı üçüncü bölümünde 307 ilâ 312'nci maddeler arasında düzenlenmektedir. Alman hukukunda ise, davadan feragat (Verzicht), Alman Medeni Usul Kanunu'nun (ZPO) \$\$ 306 vd'nda düzenlenmektedir (Bkz.: Hans-Joachim Musielak, Kommentar zur Zivilprozessordnung mit Gerichtsverfassungsgesetz (8., Neubearbeitete Auflage, Verlag Franz Vahlen München, 2011) 1034 vd.).

5 Bununla birlikte, davadan feragat yürürlükten kaldırılan 1086 sayılı Hukuk Usulü Muhakemeleri Kanunu’nun (HUMK) 91-95 hükümlerinde düzenlenmekteydi (Ergun Önen, 'Feragat ve Kabul Kesin Hüküm Teşkil Etmez' (1976) 1 ABD 26).

6 Atalı, Pekcantez Usul (n 1) 2016; Baki Kuru, Medeni Usul Hukuku El Kitabı Cilt 2 (Yetkin 2020) 1046; Kuru, Arslan ve Yılmaz, Medeni Usul (n 1) 505; Atalı, Ermenek ve Erdoğan (n 1) 574; Ali Haydar Karahacığlu ve Aynur Parlar, 6100 Sayılı Hukuk Muhakemeleri Kanunu Şerhi (Bilge, 2014) 1339. Ayrıca, davadan tamamen feragat edilebileceği gibi kısmen feragat yoluna da gidebilecektir (Atalı, Pekcanıtez Usul (n 1) 2020; Sabri Şakir Ansay, Hukuk Yargılama Usulleri (7. Bası, Ankara Üniversitesi Hukuk Fakültesi Yayınları 1960) 180; İlhan E. Postacıŏlu, Medeni Usul Hukuku Dersleri (1911 Sayılı Kanun'a Göre Yazılmış 6. Bası, Sulhi Garan 1975) 480; Kuru, Arslan ve Yılmaz, Medeni Usul (n 1) 506; Budak ve Karaaslan (n 1) N 6, s. 320; Saim Üstündağ, Medeni Yargılama Hukuku, C. I-II (Gözden Geçirilmiş ve Yenilenmiş 7. Bası, Nesil 2000) 573; Nihat Yavuz, 'Hukuk Davalarında Feragat ve Yargitay 8. Hukuk Dairesinin En Son Bir Kararı Üzerine Bazı Düşünceler’ 1977 (6) Ankara Barosu Dergisi 1019. Davadan kısmen feragat edilmesi durumunda, feragat edilen kesimin dilekçede yahut tutanakta açıkça gösterilmesi gerekmektedir (HMK m. 309/f. 3) (Atalı, Ermenek ve Erdoğan (n 1) 574; Şanal L Görgün, Levent Börü, Barış Toraman ve Mehmet Kodakoğlu, Medeni Usul Hukuku (28.07.2020 tarih ve 7251 sayılı Kanunla Değiştirilmiş, Güncellenmiş 9. Bası, Yetkin 2020) 596). Davadan kısmen feragat halinde, feragat edilen kısım için dava sona erer ve feragat edilmeyen kısım için ise dava devam edecektir (Kuru, Arslan ve Yılmaz, Medeni Usul (n 1) 506; Karslı (n 1) 373).

7 Alangoya, Yildırım ve Deren-Yıldırım, Esaslar (n 1) 422-423; Karslı (n 1) 373; Atalı, Pekcanıtez Usul (n 1) 2016; Atalı, Ermenek ve Erdoğan (n 1) 574; Kuru, Arslan ve Yılmaz, Medeni Usul (n 1) 505; Timuçin Muşul, Medeni Usul Hukuku (6100 sayılı Hukuk Muhakemeleri Kanunu Esas Alınarak Hazırlanmış 3. Bası, Adalet 2012) 437, 441; Baki Kuru, İstinaf Sistemine Göre Yazılmış Medeni Usul Hukuku Ders Kitabı (1. Bası, Yetkin 2017) 389; Görgün, Börü, Toraman ve Kodakoğlu (n 6) 596.

8 Postacıoğlu, Usul Hukuku (n 6) 479; Baki Kuru, Hukuk Muhakemeleri Usulü El Kitabı (1. Bası, Alfa 1995) 595; Karslı (n 1) 371; Muşul, (n 7) 436; Baki Kuru, Hukuk Muhakemeleri Usulü, C. IV (6. Bası, Demir-Demir 2001) 3550.

$9 \quad$ Atalı, Ermenek ve Erdoğan (n 1) 574; Kuru, Arslan ve Yılmaz, Medeni Usul (n 1) 506; Karslı (n 1) 374; Muşul, (n 7) 441; Görgün, Börü, Toraman ve Kodakoğlu (n 6) 598; Kuru, İstinaf Sistemi (n 7) 388; Atalı, Pekcanıtez Usul (n 1) 2012; Budak ve Karaaslan (n 1) N. 13, s. 322; Karahac1oğlu ve Parlar (n 6) 1341. Yarg. 23. HD, 5.3.2012, E. 2012/923, K. 2012/1647“... Feragat, 6100 sayıl HMK'nun 311. madde hükmü uyarınca, kesin hüküm sonuçlarını doğurduğu gibi, aynı Kanun’un 309/2. Maddesi uyarınca karşı tarafın kabulüne de bağlı bulunmamaktadır. Öte yandan aynı Kanun'un 310'uncu maddesi 
devam ettiği bir esnada değil; aynı zamanda, hükmün şekli anlamda kesinleşmesine kadar davadan feragat edilebilirr ${ }^{10}$. Hükmün şekli anlamda kesinleşmesinden sonra ise, ortada derdest bir dava bulunmadığ 1 için, bu aşamada davadan feragat yoluna gidilemez ${ }^{11}$. İlk derece mahkemesince hükmün verilmesinden sonra ve fakat kanun yollarına müracaat edilmesinden önce ya da dosyanın kanun yollarında incelendiği bir esnada da davadan feragat edilebilmesi mümkündür ${ }^{12}$.

Davayı sona erdiren usulî işlemlerden birisi olan feragat ${ }^{13}$, davacı tarafından yapıldığ ${ }_{1}$ anda hükümlerini doğurur ${ }^{14}$. Bu sebeple, davanın feragat sebebiyle sona erebilmesi için mahkemece bir karar verilmesine gerek yoktur ${ }^{15}$. Bununla birlikte, mahkemece, davanın feragat sebebiyle sona erdiğini tespit ve tevsik eden bir kararın verilmesi gerekmektedir ${ }^{16}$.

Dava henüz ilk derece mahkemesindeyken davacı tarafından davadan feragat edilirse, davanın feragat sebebiyle sona erdiğini tespit eden kararı verecek olan merci “ilk derece mahkemesi” olacaktır ${ }^{17}$. Bununla birlikte, ilk derece mahkemesince hüküm verildikten sonra kanun yollarına müracaat süresi içerisindeyken davadan feragat edilirse hangi merci tarafından karar verileceği konusunda, 28.07.2020 tarihli ve 7251 sayılı HMK değişikliğine kadar usul kanunumuzda bir boşluk

uyarınca davadan feragat, karar kesinleşinceye kadar her aşamada mümkündür. Mahkeme davadan el çektiğinden, karar ortada durduğu müddetçe, davayı yeniden ele alıp, feragat nedeniyle bir karar veremez (11.04.1940 gün ve 70 sayılı İBK, 21.11.1981 gün 1981/2-551 sayıl HGK karari). Bu itibarla, davadan feragat nedeniyle mahkemece bir karar verilmesi gerektiğinden, bunun sağlanabilmesi için hükmün öncelikle bu nedenle bozulması gerekmiştir." (Karahacıoğlu ve Parlar (n 6) 1341).

10 Alangoya, Yıldırım ve Deren-Yıldırım, Esaslar (n 1) 423-424; Üstündağ (n 6) 571; Postacıoğlu, Usul Hukuku (n 6) 478; Budak ve Karaaslan (n 1) N. 13, s. 322; Bilge (n 2) 309.

11 Lütfü Fikri Soner, 'Feragat, Kabul ve Sulhe Dair Bazı Sorunlar' (1977) 3 ABD 442; Postacığlu, Usul Hukuku (n 6) 478; Akyol Aslan (n 2) 250 vd.; Ansay (n 6) 181; Üstündağ (n 6) 571; Karslı (n 1) 374; Görgün, Börü, Toraman ve Kodakoğlu (n 6) 598.

12 Atalı, Ermenek ve Erdoğan (n 1) 574; Alangoya, Yıldırım ve Deren-Yıldırım, Esaslar (n 1) 423-424; Kuru, El Kitabı (n 8 ) 597; Akyol Aslan (n 2) 257 vd.; Postacıoglu, Usul Hukuku (n 6) 478; Karslı (n 1) 374.

13 Davadan feragatin davayı sona erdiren usul işlemlerinden birisi olduğu hakkında bkz.: Alangoya, Yıldırım ve DerenYıldırım, Esaslar (n 1) 422; Ramazan Arslan, Ejder Yılmaz, Sema Taşpınar-Ayvaz ve Emel Hanağası, Medenî Usul Hukuku (Güncellenmiş ve 7251 sayılı Kanun Değişiklikleri İşlenmiş 6. Bası, Yetkin 2020) 564 vd.; Atalı, Ermenek ve Erdoğan (n 1) 571 vd.; Budak ve Karaaslan (n 1) 319 vd.; Görgün, Börü, Toraman ve Kodakoğlu (n 6) 592; Karsl1 (n 1) 369-370; Kuru, C. IV (n 8) 3543; Kuru, Arslan ve Yılmaz, Medeni Usul (n 1) 505; Kuru, El Kitabı (n 8) 594; Kuru, İstinaf Sistemi (n 7 ) 386; Muşul, (n 7) 435 vd.; Atalı, Pekcanttez Usul (n 1) 2008 vd.; Postacıŏlu, Usul Hukuku (n 6) 476; Üstündağ (n 6) 568.

14 Soner (n 11) 444; Karslı (n 1) 373.

15 Atalı, Pekcantez Usul (n 1) 2015. Bununla birlikte, doktrinde bazı yazarlarca, davanın feragat sebebiyle sona erdiği konusunda mahkemece bir karar verilmesinin gerektiği kabul edilmektedir (Alangoya, Yıldırım ve Deren-Yıldırım, Esaslar (n 1) 424). Doktrinde aksi görüşteki bu yazarlara göre, davanın feragat ile değil de mahkemenin feragat hakkında vereceği karar ile sona ereceği şeklindedir. Bu görüşteki yazarlar için bkz.: Arslan, Yılmaz, Taşpınar-Ayvaz ve Hanağası, (n 13) 567.

16 Süha Tanrıver, Medenî Usûl Hukuku, C. I, Temel Kavramlar ve İlk Derece Yargılaması (Tümüyle Gözden Geçirilmiş, Yenilenmiş ve Genişletilmiş 2. Bası, Yetkin 2018) 1052. Doktrinde aksi yöndeki görüş için bkz.: Alangoya, Yıldırım ve Deren-Yıldırım, Esaslar (n 1) 424; Arslan, Yılmaz, Taşpınar-Ayvaz ve Hanağası, (n 13) 567.

17 Soner (n 11) 444. 
bulunmaktayd ${ }^{18}$. Zira, 1086 sayılı Hukuk Usulü Muhakemeleri Kanunu’nun ${ }^{19}$ yürürlükte olduğu dönemde, davadan feragati düzenleyen kanun hükümlerinin arasında (HUMK m. 91-95) bu konuya ilişkin herhangi bir düzenleme yer almamaktayd ${ }^{20}$. Bununla birlikte, hükmün verilmesinden sonra kanun yolları süresi içerisindeyken veya dosyanın kanun yollarında incelendiği bir aşamada davadan feragat edilmesi durumunda, müracaat edilecek olan merci ile bu merci tarafindan verilecek olan karar konusunda Yargitay’n yerleşik bir uygulaması söz konusuydu ${ }^{21}$.

Yargıtay’n yerleşik uygulamasına göre, ilk derece mahkemesince hüküm verildikten sonra, kanun yolu incelemesinin gerçekleştirilmesinden önce davadan feragat edilmesi durumunda feragat sebebiyle dosyanın Yargıtay’a gönderilmesi yönünde karar verilmesi gerekmekteydi ${ }^{22}$. Zira, ilk derece mahkemesi, kararını ortaya koyduktan sonra dosyadan el çekmiş olacağı için, davacı tarafından davadan feragat beyanının ileri sürülmesi üzerine hükmü veren mahkemece tekrardan inceleme yapılarak karar verilmesi söz konusu olmaz ${ }^{23}$. Böylelikle, feragat edilen dosyanın Yargıtay tarafından bozulmasından sonra, kararı veren ilk derece mahkemesine gönderileceği ve feragat sebebiyle yargılamaya son verileceği içtihat edilmekteydi ${ }^{24}$. Bununla birlikte, Hukuk Muhakemeleri Kanunu'nun 01.10.2011 tarihinde yürürlüğe girmesinden sonra getirilen Hukuk Muhakemeleri Kanunu Yönetmeliğỉnin "karar verilmiş dosyalara ilişkin işlemler" kenar başlıklı 57’nci maddesi ile Yargıtay uygulamasından farklı bir düzenleme kabul edilmiştir ${ }^{25}$. Bu durum karşısında Yargıtay, verdiği kararlarda, Hukuk Muhakemeleri Kanunu Yönetmeliği’nin 57’nci maddesinde öngörülen düzenlemenin yürürlüğe girmesinden sonra da uzun zamandan beri sürdürdüğü uygulamanın devam etmesi gerektiği yönünde içtihatlar ortaya koymuştur ${ }^{26}$.

18 İlk derece mahkemesince hüküm verildikten sonra kanun yollarına müracaat süresi içerisinde davadan feragat edilmesi durumunda hangi merci tarafından ne şekilde karar verileceği konusunda Kanunda bir boşluk söz konusuydu (Akyol Aslan (n 2) 262; Soner (n 11) 444).

19 RG., 2, 3, 4. 07. 1927, S. 622, 623, 624.

20 Bkz.: HUMK m. 91-95.

21 Yargitay uygulaması hakkında bkz.: Atalı, Pekcanitez Usul (n 1) 2013; Kuru, C. IV (n 8) 3565-3568.

22 Yarg. 2. HD, 05.05.1999, 2708/4669 “...Taraflar arasındaki boșanma davasının yapılan muhakemesi sonunda mahkemece isteğe uygun olarak boșanmaya hükmedilmiş, temyiz süresi içinde davacı 7.12.1988 tarihli dilekçesi ile davadan feragat etmiştir. Karar kesinleşinceye kadar davanin her safhasinda davadan feragat mümkündür. Feragat kesin hükmün hukuki neticelerini doğurur (HUMK m. 95). Öte yandan işlem doğrultusunda oluşan hükmün kesinleşmesi bu kuralla çelişen bir sonuç doğuracaktır. O halde, henüz kesinleşmemiş hükmün ortadan kaldırılması zorunludur. Mahkemeler Kanunda öngörülen istisnalar dışında kendi hükümlerini kendileri kaldıramazlar. İlk derece mahkemelerinin kararların bozup kaldırma yetkisi münhasıran Yargıtaya aittir (Yargitay Kanunu 1; HUMK m. 428). Mahkemece kadının davası kabul edilerek boşanmaya karar verilmekle dosyadan el çekilmiştir. Davacı kadının hüküm kesinleşmeden önce verdiğ 7.12 .1998 tarihli dilekçesinin temyiz isteği olarak kabulü ile, dosyanın ele alınp feragat sebebi ile gerekli kararın verilmesi gerekirken ek kararla davanin feragat sebebi ile gerekli kararın verilmesi gerekirken ek kararla davanin feragat sebebi ile reddine karar verilmesi doğru görülmemiştir...” (YKD 1999/10, s. 1364; Aynı karar için bkz.: Kuru, C. IV (n 8) 3567).

23 Evren Koç ve Cengiz Serhat Konuralp, Adli Yargı İlk Derece Mahkemeleri ve Bölge Adliye Mahkemesi Kalem Mevzuatı (Sümer, 2017) 66.

24 Budak ve Karaaslan (n 1) N. 13, s. 322. Yarg. 8. HD, 28.02.2017, E. 2016/10528, K. 2017/2702 “...Karar kesinleşinceye kadar davadan feragatin mümkün olduğuna, Mahkemece, bir karar verilip, davadan el çektikten sonra temyiz aşamasında davacı asil tarafindan davadan feragat edildiğine ve bu aşamada feragat hakkında karar verme yetkisi yerel mahkemeye ait bulunduğuna göre, davacının davadan feragat beyanı hakkında bir karar verilmek üzere bozulması gerekmektedir" (e-uyar).

Atali, Pekcantez Usul (n 1) 2013.

Yarg. 22. HD. 15.2.2016, E. 2015/19288, K. 2016/3686 “...Bir kısım işçilik alacaklarının ödetilmesi istemi ile açılan davada 
Hukuk Muhakemeleri Kanunu Yönetmeliği’nin yürürlükten kaldırılmasından sonra onun yerine Bölge Adliye ve Adli Yargı İlk Derece Mahkemeleri ile Cumhuriyet Başsavcılıkları İdari ve Yazı İşleri Hizmetlerinin Yürütülmesine Dair Yönetmelik (“Yazı İşleri Yönetmeliği”) kabul edilerek yürürlüğe konulmuştur ${ }^{27}$. Kanun koyucu, yeni Yönetmelik ile getirilen 215 'inci madde hükmünde, yürürlükten kaldırılan Hukuk Muhakemeleri Kanunu Yönetmeliği’nin 57’nci maddesinde öngörülen esaslarla birebir aynı düzenlemeleri kabul etmiştir ${ }^{28}$. Buna göre, Yazı İşleri Yönetmeliği’nin 215’inci maddesinde, ilk derece mahkemesince hükmün verilmesinden sonra ve fakat şekli anlamda kesinleşmesinden önce davadan feragat edilmesi durumunda, hâkimin dosya üzerinden "ek karar" alabileceği; böylelikle, dosyanın istinaf ve temyiz incelemesine gönderilemeyeceği öngörülmüştür ${ }^{29}$.

Doktrinde, yönetmelik hükümleriyle düzenleme getirilmesi eleştirilerek, bu konuda Hukuk Muhakemeleri Kanunu’nda da bir hükmün sevk edilmesinin gerektiği ileri sürülmüştür ${ }^{30}$. 28.07.2020 tarihli ve 7251 sayılı Hukuk Muhakemeleri Kanunu ile Bazı Kanunlarda Değişiklik Yapılması Hakkında Kanunla ${ }^{31}$ gerçekleştirilen değişiklikler sonrasında, davadan feragatin gerçekleştirilme zamanı ile davadan feragat üzerine davanın sona erdiğini tespit eden kararı verecek olan merciin neresi olduğu hakkında düzenlemeler yapılmıştır. Böylelikle, yönetmelik hükümleriyle kabul edilen ve uygulamada var olan durum, Hukuk Muhakemeleri Kanunu'nda da düzenlenerek kanuni bir zemine kavuşturulmuştur ${ }^{32}$. Kanaatimizce, yönetmeliklerle öngörülen düzenlemeye kanuni bir temel kazandırılması ve Hukuk Muhakemeleri Kanunu'nda ilk defa “ek karar” kavramına yer verilmesi

mahkemece davamin kısmen kabulüne iliskin verilen karar, davalı ve davacı vekilleri tarafindan temyiz edilmiş ve dosya temyiz incelemesi için dairemize gönderilmiştir. Davacı vekili 09.02.2016 tarihli dilekçesi ile davadan ve temyizden feragat ettiğini bildirmiştir. 06.08.2015 tarihli ve 29437 sayll Resmî Gazete'de yayımlanarak yürürlüğe giren, Bölge Adliye ve Adli Yargı İlk Derece Mahkemeleri ile Cumhuriyet Başsavcılıkları İdari ve Yazı İșleri Hizmetlerinin Yürütülmesine Dair Yönetmeliğin 215. maddesinde "Hükmün kesinleşmesinden önce davadan feragat, davayı kabul veya sulh halinde, hâkim dosya üzerinden bu konuda ek karar verir. Taraflarca kanun yoluna başvurulmuş olsa dahi sirf bu nedenlerle dosya istinaf veya temyiz incelemesine gönderilmez." düzenlemesi yer almaktadır. Anılan sebeple, hükümden sonra ortaya çıan ve temyiz incelemesine usulen engel oluşturan davadan feragat beyanının mahkemece değerlendirilip karara bağlanması için dosyanın mahkemesine iadesine karar vermek gerekmiștir..." (Lexpera).

27 RG. 3.4.2012, S. 28253.

28 Yürürlükten kaldırılan Hukuk Muhakemeleri Kanunu Yönetmeliği’nin 57’nci maddesinde, “Hükmün kesinleşmesinden önce davadan feragat, davayı kabul veya sulh halinde, hâkim dosya üzerinden bu konuda ek karar verir. Taraflarca kanun yoluna başvurulmuş olsa dahi surf bu nedenlerle dosya istinaf veya temyiz incelemesine gönderilmez." denilmektedir. 06.08.2015 tarihinde yürürlüğe giren Bölge Adliye ve Adli Yargı İlk Derece Mahkemeleri ile Cumhuriyet Başsavcılıkları İdari ve Yazı İșleri Hizmetlerinin Yürütülmesine Dair Yönetmeliğin 215. maddesi de aynı düzenlemeyi içermektedir (Yarg. 23. HD, 21.04.2016, E. 2015/8604, K. 2566, e-uyar). Yönetmeliğin 215’inci maddesinde, "Hükmün kesinleşmesinden önce davadan feragat, davayı kabul veya sulh hâlinde, hâkim dosya üzerinden bu konuda ek karar verir. Taraflarca kanun yoluna başvurulmuş olsa dahi sirf bu nedenlerle dosya istinaf veya temyiz incelemesine gönderilmez." denilmektedir.

Atali, Pekcanitez Usul (n 1) 2013.

30 Sema Taşpınar Ayvaz, 'HMK Yönetmeliği ile Usul hükmü Getirilemez' 2013/3 Güncel Hukuk Dergisi 552-555.

31 RG., 22.07.2020, S. 31199.

32 Selçuk Öztek, Sema Taşpınar Ayvaz ve Serdar Kale, 'Hukuk Muhakemeleri Kanunu ile Bazı Kanunlarda Değişiklik Yapılması Hakkında 20 Mart 2020 Tarihli Kanun Teklifíne İlişkin Bazı Açılamalar ve Kanun Teklifinin Değerlendirilmesi' (2020) Temmuz-Ağustos 33(149), Türkiye Barolar Birliği Dergisi, 138-139; Hakan Pekcanitez, Oğuz Atalay ve Muhammet Özekes, 'Hukuk Muhakemeleri Kanunu ile Bazı Kanunlarda Değişiklik Yapılmasına Dair Kanun Teklifinin (2020) Değerlendirilmesi', LexperaBlog, (30.03.2020) <https://blog.lexpera.com.tr/hmk-ile-bazi-kanunlardadegisiklik-yapilmasina-dair-kanun-teklifinin-2020-degerlendirilmesi/> (Son Erişim Tarihi: 29.07.2020). 
bakımından gerçekleştirilen değişiklik önem arz etmektedir ${ }^{33}$. Bu sebeple, çalışmamızda, öncelikle, Hukuk Muhakemeleri Kanunu’nda düzenlenmekte olan davadan feragat hakkında açıklamalarda bulunulacak ve davadan feragatin hukuki niteliği, şekli ile zamanı ifade edilecektir. Sonrasında ise, hükmün verilmesinden sonra davadan feragat edilmesi üzerine karar verecek olan merci; doktrinde ileri sürülen görüşler, Yargıtay kararlarıyla şekillenen uygulama ve Yönetmelik hükümleri (eski HMK Yönetmeliği m. 57; Yazı İşleri Yönetmeliği m. 215) ile 28.07.2020 tarihinde gerçekleştirilen 7251 sayılı Hukuk Muhakemeleri Kanunu değişikliği çerçevesinde değerlendirilerek ortaya konulmaya çalışılacaktır.

\section{DAVADAN FERAGAT HAKKINDA GENEL BILGILER}

\section{A. DAVADAN FERAGAT KAVRAMI}

Davadan feragat, davacının dava dilekçesinde yer alan talep sonucundan kısmen veya tamamen vazgeçmesidir ${ }^{34}, 35$ (HMK m. 307). Davadan feragat eden davac1, mahkemeye müracaat ederek, dava dilekçesindeki talep sonucundan kısmen veya tamamen vazgeçtiği hususunu ortaya koymaktadır ${ }^{36}$. Davacı, davadan feragat yoluna müracaat etmekle sadece davasını geri almış olmamakta; aynı zamanda, davaya konu edilen haktan da vazgeçmiş sayılmaktadır ${ }^{37}$. Bu sebeple, feragat edilen davaya konu olan hakkın tekrardan başka bir davada ele alınabilmesi mümkün olmamaktadır ${ }^{38}$.

33 Öztek, Taşpınar Ayvaz ve Kale (n 32) 138.

34 Davadan feragat hakkında çeşitli tanımlar ve kavramsal açıklamalar için bkz.: Akyol Aslan (n 2) 65 vd.; Hakan Pekcanıtez, Oğuz Atalay ve Muhammet Özekes, Medeni Usul Hukuku Ders Kitabı (7035, 7101 ve 7155 Sayılı Kanunlarla Yapılan Değişiklikler Nazara Alınarak Gözden Geçirilmiş 8. Bası, On İki Levha, 2020) 437; Atalı, Ermenek ve Erdoğan (n 1) 572; Atali, Pekcanttez Usul (n 1) 2011; Karslı (n 1) 370; Budak ve Karaaslan (n 1) N. 11, s. 321; Kuru, Arslan ve Y1lmaz, Medeni Usul (n 1) 505; Muşul, (n 7) 436; Görgün, Börü, Toraman ve Kodakoğlu (n 6) 592; Kuru, İstinaf Sistemi (n 7) 386; Tanrıver, Medenî Usûl C. I (n 16) 1046; Alangoya, Yıldırım ve Deren-Ylldırım, Esaslar (n 1) 422; Ömer Uğur Gençcan, 6100 Sayıl Hukuk Muhakemeleri Kanunu Yorumu, Bilimsel Açıklama-Son İçtihatlar (Yetkin 2013) 1067. Bununla birlikte, 1086 sayılı Hukuk Usulü Muhakemeleri Kanunu’nun 91'inci maddesinde "Feragat, iki taraftan birinin neticei talebinden vazgeçmesidir" şeklinde ifade edilmekteydi (Postacıoğlu, Usul Hukuku (n 6) 476; Üstündağ (n 6) 571; Kuru, El Kitabı (n 8) 595; Kuru, C. IV (n 8) 3544).

35 Davadan feragat, Alman Medeni Usul Kanunu’nda (ZPO) $\$ 306$ hükmünde düzenlenmektedir. $\$ 306$ ZPO hakkında bkz.: Ingo Saenger, Zivilprozessordnung: ZPO (Familienverfahren, Gerichtsverfassung, Europaische Verfahrensrecht), Handkommentar, (8. Auflage, Nomos, 2019), \$ 306, N. 1; Leo Rosenberg, Karl Heinz Schawb und Peter Gottwald, Zivilprozessrecht (17., neu bearbeitete Auflage, München, Verlag C. H. Beck oHG, München, 2010) §132, Rdn. 68; HansJoachim Musielak, Münchener Kommentar zur Zivilprozessordnung Bd. 1: \$\$ 1-354, Wolfgang Krüger (Hrsg.) (6. Auflage, C.H.Beck 2020) $\$ 306$, N. 2; Beck'scher Online-Kommentar ZPO, (Herausgegeben von Volkert Vorwerk und Christian Wolf) (36. Edition, Stand: 01.03.2020, Verlag C.H. Beck München 2020) marg. 2.

36 Atalı, Pekcanttez Usul (n 1) 2020; Ansay (n 6) 180; Postacıoğlu, Usul Hukuku (n 6) 480; Kuru, Arslan ve Yilmaz, Medeni Usul (n 1) 506; Karslı (n 1) 373; Budak ve Karaaslan (n 1) N. 6, s. 320; Üstündağ (n 6) 573; Yavuz (n 6) 1019; Gençcan (n 34) 1067.

37 Saenger, ZPO $\$ 306$ (n 35) N. 1; Hans-Joachim Musielak und Wolfgang Voit, Zivilprozessordnung: ZPO mit Gerichtsverfassungsgesetz (17., neubearbeitete Auflage, Verlag Franz Vahlen, 2020) §306, Rdn. 2; Kuru, İstinaf Sistemi (n 7) 386; Kuru, C. IV (n 8) 3545; Atalı, Pekcanttez Usul (n 1) 2012; Karslı (n 1) 370; Gençcan (n 34) 1067.

38 Görgün, Börü, Toraman ve Kodakoğlu (n 6) 592; Karslı (n 1) 370-371; Gençcan (n 34) 1067. Yarg. 21. HD, 8.2.2005, 2004/12344-816 "feragate konu teşkil eden hak tamamen düşer ve artık bir daha dava edilemez" (YKD 2005/9, s. 1430; Alangoya, Yıldırım ve Deren-Ylldırım, Esaslar (n 1) 423). Yargıtay kararında, davacının kullandığı "yeniden dava 
Davacı, davadan feragat iradesini ortaya koyarken başka bir müessese ile karıştırılamayacak bir ifadeye yer vermelidir ${ }^{39}$. Zira, uygulamada, davadan feragat ile benzer müesseselerin karıştırıldığ 1 görülmektedir ${ }^{40}$. Buna göre, davadan feragat ile "davanın geri alınması" (HMK m. 123; HUMK m. 185/f. 1; ZPO \$ 269) farklı müesseseler ${ }^{41}$ olmakla birlikte çoğu zaman hatalı bir şekilde birbirlerinin yerine kullanılmaktadır ${ }^{42}$. Bu sebeple, davadan feragat edilmek istenirken, Hukuk Muhakemeleri Kanunu’nun 123'üncü maddesinde (HUMK m. 185/f. 1; ZPO \$ 269) öngörülen “davanın geri alınması" ile karıştııılmayacak bir ifadenin kullanılmasına özen gösterilmelidir ${ }^{43}$.

Davanın geri alınmasına ilişkin olarak Hukuk Muhakemeleri Kanunu m. 123'te "Davacı, hüküm kesinleşinceye kadar, ancak davalının açık rızası ile davasını geri alabilir" ${ }^{\prime 4}$ denilmektedir ${ }^{45}$. Hukuk Muhakemeleri Kanunu’nun 123'üncü maddesinin lafzından da anlaşılacağ 1 üzere, davanın geri alınması bazı yönleriyle HMK m. 307'de düzenlenen davadan feragat müessesesinden farklılık arz etmektedir ${ }^{46}$. Zira, davanın geri alınmasında davacı, davaya konu edilen haktan vazgeçmemekte;

açabilmek için süresinden önce ikame ettiğim bu davadan feragat ediyorum" şeklindeki beyanın davadan feragati değil; davanın geri alınmasını sonuçlayacağı ifade edilmektedir (Yarg. 2. HD, 27.10.1995 8962/10941 Yasa 1996/5 s. 927; Alangoya, Yıldırım ve Deren-Yildırım, Esaslar (n 1) 423).

39 Görgün, Börü, Toraman ve Kodakoğlu (n 6) 594; Kuru, C. IV (n 8) 3544; Kuru, El Kitabı (n 8) 595. Bu kapsamda, Yargitay kararlarında, boşanma davası esnasında, eşlerden birinin diğerinden nafaka ve tazminat istemiyorum şeklindeki beyanı davadan feragat olarak kabul edilmektedir (Yarg. 2. HD, 19.03.2013, E. 2012/21182, K. 2013/7436, Legal Elektronik Hukuk Bankası; Hukuk Türk Hukuk Veri Tabanı). Buna karşılık, davacının istinaf dilekçesinde yer alan "tazminat ve nafaka verilmezse boşanmak istemiyorum" şeklindeki beyanı davadan feragat iradesi olarak kabul edilemeyecektir (Görgün, Börü, Toraman ve Kodakoğlu (n 6) 595). Yargıtay’n bu yöndeki bir kararı için bkz.: YHGK, 12.09.2012, E. 2012/2-245, K. 2012/554 (Legal Elektronik Hukuk Bankasi).

40 Uygulamada, HMK m. 307 vd.'nda (HUMK m. 95 vd.) düzenlenmekte olan davadan feragat müessesesi yerine "davadan vazgeçme" tabiri de kullanılmaktadır. Bununla birlikte, davadan vazgeçme tabiri, davanın geri alınması için de kullanıldığından davadan feragat müessesesi ile sıklıkla karıştııılmaktadır (Kuru, Arslan ve Yılmaz, Medeni Usul (n 1) 505). HMK m. 123'de öngörülen (HUMK m. 185/f. 1) davanın geri alınması davadan feragatten farklılık arz etmektedir (Atall, Pekcanttez Usul (n 1) 2012; Görgün, Börü, Toraman ve Kodakoğlu (n 6) 593; Kuru, İstinaf Sistemi (n 7) 387; Atalı, Ermenek ve Erdoğan (n 1) 572; Postacioğlu, Usul Hukuku (n 6) 479; Üstündağ (n 6) 571; Muşul, (n 7) 437; Budak ve Karaaslan (n 1) N. 11, s. 321; Kuru, El Kitabı (n 8) 595; Alangoya, Ylldırım ve Deren-Ylldırım, Esaslar (n 1) 423; Kuru, Arslan ve Yilmaz, Medeni Usul (n 1) 505).

41 Saenger, ZPO $\$ 306$ (n 35) N. 1; Pekcanitez, Atalay ve Özekes, (n 34) 438.

42 Akyol Aslan (n 2) 70. Davadan feragat ile davanın geri alınması arasındaki farklar hakkında açıklamalar için bkz.: Postacioğlu, Usul Hukuku (n 6) 479; Atalı, Pekcanitez Usul (n 1) 2012; Kuru, Arslan ve Yllmaz, Medeni Usul (n 1) 505; Alangoya, Yıldırım ve Deren-Yıldırım, Esaslar (n 1) 423; Görgün, Börü, Toraman ve Kodakoğlu (n 6) 593; Budak ve Karaaslan (n 1) N. 11, s. 321; Atal, Ermenek ve Erdoğan (n 1) 572.

43 Akyol Aslan (n 2) 65-66; Görgün, Börü, Toraman ve Kodakoğlu (n 6) 594.

446100 sayılı Hukuk Muhakemeleri Kanunu’nun 123’üncü maddesinde düzenlenen “davanın geri alınması"nın 1086 sayılı Hukuk Usulü Muhakemeleri Kanunu’ndaki karşllı̆̆ı, 185/f. 1'de düzenlenmekteydi. Söz konusu düzenleme şu şekildedir: "Kanunu Medenide tayin olunan haller mahfuz kalmak şartiyle dava ikamesi ile aşağıda gösterilen neticeler hasıl olur: 1.Müddeaaleyhin rizası olmaksızın müddei davasını takipten sarfinazar edemez." https://www.mevzuat.gov.tr/ MevzuatMetin/5.3.1086.pdf (Çevirimiçi, Erişim Tarihi: 19.05.2020).

45 HMK m. 123’te düzenlenen davanın geri alınması hakkında bkz.: Budak ve Karaaslan (n 1) 213; Kuru, Arslan ve Yilmaz, Medeni Usul (n 1) 292; Atalı, Ermenek ve Erdoğan (n 1) 382-383.

46 Saenger, ZPO $\$ 306$ (n 35) N. 1; Atalı, Pekcanitez Usul (n 1) 2012; Atalı, Ermenek ve Erdoğan (n 1) 572; Budak ve Karaaslan (n 1) N. 11, s. 321; Karslı (n 1) 371; Muşul, (n 7) 437; Görgün, Börü, Toraman ve Kodakoğlu (n 6) 593; Kuru, İstinaf Sistemi (n 7) 387. Benzer şekilde, 1086 sayılı HUMK döneminde, davadan feragat kurumu m. 185'te düzenlenmekte olan davayı geri alma (davanın takibinden sarfınazar etme) müessesesi ile karıştırılmaktaydı (Kuru, El Kitabı (n 8) 595; Kuru, C. IV (n 8) 3544; Alangoya, Yıldırım ve Deren-Yıldırım, Esaslar (n 1) 423; Üstündağ (n 6) 571). Yargıtay’ın bu yöndeki 
aksine, davasını ileride açabilme imkânını saklı tutarak o an için geri almaktadır ${ }^{47}$. Bunun neticesinde, Hukuk Muhakemeleri Kanunu'nun 123'üncü maddesi uyarınca geri alınan dava, dava konusu haktan vazgeçilmiş olmadığ 1 için daha sonra tekrardan açılabilmektedir ${ }^{48}$. Diğer taraftan, davadan feragatte, aynı zamanda dava konusu olan haktan da feragat edildiği için ${ }^{49}$ davacının feragat ettiği davayı tekrardan yargı önüne taşıyabilmesi mümkün olmamaktadır ${ }^{50}$. Aksi takdirde, davacı, bir dava şartı olan kesin hükmü mahkemede ileri sürerek (HMK m. 114/f. 1, i) davanın usulden reddedilmesini sağlayabilecektir ${ }^{51}$. Davadan feragat ile davanın geri alınması arasındaki bir diğer fark ise, karşı tarafın rızasının gerekip gerekmediği noktasındadır ${ }^{52}$. Zira, davanın geri alınabilmesi için davalının açık rızasına ihtiyaç bulunmaktayken ${ }^{53}$; davadan feragatte davacı, karşı tarafın rızasını almak zorunda değildir ${ }^{54}$ (HMK m. 309). Ayrıca, vekil ile temsil edilen davalarda, davanın geri alınabilmesi için davacı vekilinin vekaletnamesinde özel olarak davayı geri alma yetkisinin bulunmasına gerek yoktur ${ }^{55}$. Buna karşılık, davadan feragat edilebilmesi için davacı vekilinin vekaletnamesinde HMK m. 74 uyarınca, özel bir yetkinin bulunması şarttır ${ }^{56}$.

Uygulamada, mahkemeye sunulan dilekçelerde davadan feragat kavramının yerine sıklıkla "davayı atiye terk etme" ${ }^{57}$ ifadesi de kullanılmaktadir ${ }^{58}$. Bununla birlikte, Yargitay kararlarında ${ }^{59}$, davadan

bir kararı şu şekildedir: "HUMK m. 91'deki "vazgeçme" terimi HUMK 185/I’deki davanın, davalının muvafakati ile geri alınmasını hatırlatması bakımından yanıltıcıdır;” ...yazılı olduğu şekilde davalının feragati kabul etmediğinden bahisle, yargılamaya devam olunarak davanın kanıtlanmamış olduğu gerekçesi ile reddine karar verilmesi usule aykırı"dır" (Yarg. 19. HD 30.9.1997, 48128/7838, YKD 1998/8, s. 1198; Alangoya, Ylldırım ve Deren-Ylldırım, Esaslar (n 1) 422 dn. 5). Akyol Aslan (n 2) 73; Kuru, İstinaf Sistemi (n 7) 387; Atal1, Pekcantez Usul (n 1) 2012.

48 Atal, Ermenek ve Erdoğan (n 1) 572; Muşul, (n 7) 437.

49 Kuru, İstinaf Sistemi (n 7) 387; Karslı (n 1) 370-371.

50 Atalı, Ermenek ve Erdoğan (n 1) 572; Karslı (n 1) 370-371; Budak ve Karaaslan (n 1) N. 11, s. 321; Kuru, İstinaf Sistemi (n 7) 387.

51 Kuru, İstinaf Sistemi (n 7) 387.

52 Postacıoğlu, Usul Hukuku (n 6) 479; Alangoya, Yıldırım ve Deren-Ylldırım, Esaslar (n 1) 423; Atalı, Ermenek ve Erdoğan (n 1) 572; Budak ve Karaaslan (n 1) N. 11, s. 321.

53 Atalı, Pekcanttez Usul (n 1) 2012; Atalı, Ermenek ve Erdoğan (n 1) 572; Budak ve Karaaslan (n 1) N. 11, s. 321; Kuru, İstinaf Sistemi (n 7) 387; Karslı (n 1) 371; Muşul, (n 7) 437.

54 Kuru, İstinaf Sistemi (n 7) 387; Atalı, Ermenek ve Erdoğan (n 1) 572; Budak ve Karaaslan (n 1) N. 21, s. 321; Karslı (n 1) 371. Yarg. 13. HD, 21.5.1984, 2810/3588 “...Davacı asilin, 2.4.1977 tarihli 25.5.1977 havale günlü davadan feragat dilekçesi dosyaya konmuştur. 15.10 .1977 günlü dilekçesiyle de feragat dilekçesinin karşı tarafa tebliğ edilmediği gerekçesi ile feragatten vazgeçtiği bildirilmiştir. Davacı vekili de 15.11.1977 tarihli celsede feragata ilişkin dilekçelerdeki imzaların müvekkiline ait olduğunu doğrulamıștır. HUMK'nun 93. Maddesine göre feragat dilekçesi ile veya yargılama sırasında sözlü olarak yapılır. 2494 sayıl Kanunla 93. Maddede yapılan değişiklikle, feragat dilekçesinin karşı tarafa tebliği, davanın uzamasindan başka sonuç doğurmadığından tebliği hususu madde metninden çıkartılmıştır. Çünkü feragatin sonuç doğurması karşı tarafin kabulüne bağlı değildir..." (IKİD 1984/284, s. 2801; Alangoya, Ylldırım ve Deren-Ylldırım, Esaslar (n 1) 422-423, dn. 5).

55 Akyol Aslan (n 2) 76; Kuru, C. IV (n 8) 3550.

56 Kuru, El Kitabı (n 8) 596; Kuru, C. IV (n 8) 3550.

57 Uygulamada, "davayı atiye terk etme" kelimesinden başka aynı anlamı karşllayacak şekilde "davayı atiye bırakma" ifadesi de kullanılmaktadır.

58 Davayı atiye terk etme ile davadan feragat müessesinin farklılık arz ettiği konusunda açıklama için bkz.: Görgün, Börü, Toraman ve Kodakoğlu (n 6) 595.

59 Yarg. 1. HD, 08.11.2012, 11250/12498 “...Yanlar arasında görülen elatmanın önlenmesi davası sonunda, yerel mahkemece davanın, kabulüne ilişkin olarak verilen karar davah tarafindan yasal süre içerisinde duruşma istemli temyiz edilmiş olmakla dosya incelendi, Tetkik Hakimi H.Fatih Demirer'in raporu okundu, açılamaları dinlendi, davacı, davasından 
feragat kavramını karşılamak üzere kullanılan "davayı atiye terk etme" ifadesinin, davadan feragat olarak nitelendirilemeyeceği belirtilmektedir ${ }^{60}$. Yargıtay, aynı zamanda, davacının ileri sürdügü "davayı kabul etmiyorum" şeklindeki beyanın da davadan feragat olarak değerlendirilemeyeceğini ortaya koymaktadır ${ }^{61}$.

Davacı, davadan feragat etmek isterken "feragat" kelimesini bizzat kullanmak zorunda değildir ${ }^{62}$. Buna göre, feragat kelimesine yer vermemekle birlikte, dava dilekçesindeki talep sonucundan geri dönülemeyecek bir şekilde vazgeçtiğini ortaya koyan herhangi bir ifadeye yer vermesi yeterlidir ${ }^{63}$.

Davadan feragat için, feragat beyanının "açık" olması ${ }^{64}$ ve davacının gerçek iradesinin davadan feragat etmek olduğunun anlaşılabiliyor olması gerekmektedir ${ }^{65}$. Bu sebepledir ki, davadan zımnî feragat kural olarak mümkün değildir ${ }^{66}$. Bununla birlikte, davacının gerçek iradesinin davadan feragat etmek olup olmadığının anlaşılamadığı bir durumda, mahkemece davacının gerçek amacının ne olduğu hususunun açıklattırılması ve bunun üzerine talebinin işleme konulması gerekmektedir ${ }^{67}$.

HukukMuhakemeleriKanunu’ndadavadanferagatedebilmeimkânıancak“davacıya”tanınmaktadır ${ }^{68}$ (HMK m. 307). Yürürlükten kaldırılan 1086 sayılı Hukuk Usulü Muhakemeleri Kanunu’nda ise,

feragat ettiğinden duruşma isteğinin reddiyle, evrak üzerinden inceleme yapılarak, gereği görüşülüp düşünüldü; Dava, çapl taşınmazlara elatmanın önlenmesi isteğine ilişkindir. Mahkemece davanın kabulüne karar verilmiş olup, kararın davalı tarafindan temyiz edildiği görülmektedir. Ne varki, davacı vekili temyiz aşamasında verdiği 17.10.2012 havale tarihli dilekçe ile, "dava hakkı baki kalmak üzere taleplerini atiye bırakarak davadan feragat ettikleri" beyan etmiştir. O halde, davacı vekilinin anılan dilekçesinin değerlendirilerek bir karar verilmesi bakımından hüküm bozulmalıdır. Davalının temyiz isteği bu sebeple yerindedir. Kabulülle hükmün açıklanan nedenden ötürü (6100 sayıl Yasanın geçici 3.maddesi yollaması ile) 1086 sayılı HUMK'nın 428.maddesi gereğince BOZULMASINA, alınan peşin harcın temyiz edene geri verilmesine, 08.11.2012 tarihinde oybirliğiyle karar verildi..." (e-uyar).

60 Görgün, Börü, Toraman ve Kodakoğlu (n 6) 595.

61 Alangoya, Yıldırım ve Deren-Yıldırım, Esaslar (n 1) 422; Kuru, C. IV (n 8) 3549. Yargıtay’’n bu yöndeki bir kararı için ayrıca bkz.: Yarg. 19. HD, 4.7.1994, 93/6404-7218 (İlter Erdemir, Hukuk Usulü Muhakemeleri Kanunu Şerhi (2. Bası, Cilt 1-2 Sim Matbaacilik 1988) 717).

62 Alangoya, Yıldırım ve Deren-Yıldırım, Esaslar (n 1) 422; Görgün, Börü, Toraman ve Kodakoğlu (n 6) 594.

63 Görgün, Börü, Toraman ve Kodakoğlu (n 6) 594; Alangoya, Yildırım ve Deren-Yıldırım, Esaslar (n 1) 422.

64 Saenger, ZPO $\$ 306$ (n 35) N. 1.

65 Kuru, C. IV (n 8) 3593; Alangoya, Yildırım ve Deren-Ylldırım, Esaslar (n 1) 422. Yarg. 2. HD, 4.7.2011, E. 2010/10232, K. 2011/11439 "...Davadan feragat beyanı, davacının neticei talebinden tamamen veya kısmen vazgeçmesi (HUMK $m$. 91) olduğu göre, bu iradeyi açıç̧a ve tereddüte mahal bırakmaksızın gösterdiği takdirde hukuki sonuç doğurur. Davacının temyiz dilekçesinde davadan feragat ettiğine ilişkin açık bir beyanı bulunmamaktadır. Davada haklı çıkmışolan taraf da hukuki yararı bulunmak şartıyla hükmü temyiz edebildiğine (HUMK m. 427/1) göre, davacının hükmün boşanmaya ilişkin bölümünü temyiz etmiş olmast, "davadan feragat" olarak nitelendirilemez. Bu sebeple değerli çoğunluğun temyiz dilekçesini davadan feragat olarak nitelendiren görüşüne katılmyoruz, temyiz sebeplerinin incelenmesi gerektiğini düssüyoruz..." (Karahacioğlu ve Parlar (n 6) 1340-1341).

66 Kuru, C. IV (n 8) 3595; Görgün, Börü, Toraman ve Kodakoğlu (n 6) 594.

67 ibid 3593. Davacının yapmak istediği işlem davayı geri almak olmakla birlikte yanlışlıkla davadan feragat terimi kullanılmış ise, mahkemece bu hususun tespit edilmesi üzerine, davacını gerçek iradesinin davayı geri almak olduğu şeklinde yorumlanarak davanın geri alınmasına (HMK m. 123) göre bir işlem yapılması gerekmektedir. Ayrıca, davadan feragat deyimi yerine davacı tarafından davadan vazgeçme ifadesine yer verilmişse böyle bir durumda da mahkemece davacının amacının davayı geri almak mı yoksa davadan feragat etmek mi olduğu hususunun açıklattırılması gerekecektir (Kuru, C. IV (n 8) 3593).

68 Postacıoğlu, Usul Hukuku (n 6) 479; Kuru, El Kitabı (n 8) 595; Karslı (n 1) 371; Muşul, (n 7) 436; Kuru, C. IV (n 8) 3550. Alman Hukukunda aynı yönde bkz.: Rosenberg, Schwab und Gottwald, $\$ 132$ (n 35) Rdn. 69. 
davadan feragatin davanın her iki tarafınca gerçekleştirilebileceği düzenlenmekteydi ${ }^{69}$ (HUMK m. 91). Bununla birlikte, 6100 sayılı Hukuk Muhakemeleri Kanunu'nun 307'nci maddesinde ifade edilen ve "davacının" talep sonucundan vazgeçmesi olarak öngörülen düzenleme kanaatimizce daha isabetli olmuştur ${ }^{70}$. Zira, mahkemeye müracaat ederek talepte bulunan davacı olduğuna göre, bundan feragat edebilme imkânı da ancak davacıya ait olacaktır ${ }^{71}$. Bununla birlikte, - istisnaen - karşı davanın (HMK m. 132) açılması durumunda, davalının karşı davadaki talep sonucundan feragat edebilmesi de mümkün olacaktır ${ }^{72}$. Ayrıca, davacının feragat ettiği bir davada, davalı da mahkemece kendi lehine hükmedilecek olan yargılama giderlerinden feragat edebilecektir ${ }^{73}$.

Davacı, kural olarak, hiçbir kayda tabi olmaksızın her türlü davadan feragat edebilir ${ }^{74}$. Zira, kimse açmış olduğu bir davaya devam etmeye zorlanamaz ${ }^{75}$. Kural bu olmakla birlikte, uygulamada, bazı istisnai davalar bakımından, davadan feragat yoluna gidilemeyeceği kabul edilmektedir ${ }^{76}$. Buna göre, Hukuk Muhakemeleri Kanunu’nun 70'inci maddesinin 3’üncü fikrası uyarınca, Cumhuriyet Savcısı̉nın yer aldığı dava ve işler üzerinde taraflarca serbestçe tasarruf edilemeyeceği gerekçesiyle davadan feragat yoluna gidilemez ${ }^{77}$. Davadan feragat, hakimlerin hukuki sorumluluğu sebebiyle devlet aleyhine açılacak olan tazminat davaları (HMK m. 46) bakımından da söz konusu olmaz ${ }^{78}$.

İflas davalarına ilişkin olarak ise, davadan feragati kısıtlayan açık bir kanun hükmü bulunmaktadır ${ }^{79}$. 2004 sayılı İcra ve İflâs Kanunu’nun ${ }^{80}$ (İ̈K) 165 'inci maddesinin 2'nci fikrası uyarınca, asliye ticaret mahkemesince iflası istenen bir tacir hakkında iflas kararı verilirse iflas kararından sonra davadan feragat geçerli olmaz ${ }^{81}$. Ayrıca, Yargıtay kararlarında, sosyal güvenlik hakkından feragatin caiz

69 Üstündağ (n 6) 571; Postacioğlu, Usul Hukuku (n 6) 476; Kuru, El Kitabı (n 8) 595; Kuru, C. IV (n 8) 3544.

70 Bkz:: Muşul, (n 7) 436. Yargılamada, davalının talebi, kendisine karşı açılan davanın reddedilmesi olduğuna göre, yürürlükten kaldırılan 1086 sayılı HUMK m. 91'de ifade edilen şekilde davalının da talep sonucundan vazgeçmesini öngören düzenleme temelde davalının kendisine karşı açılan davadaki talep sonucunu kabul etmesi anlamına gelecektir. Diğer bir deyişle, davalının talep sonucundan vazgeçmesi "kabul" kavramına karşıllk geleceğinden her iki tarafın da davadan vazgeçmesinin feragat anlamına geleceğini öngören HUMK m. 91 hükmü isabetsizdi (Muşul, (n 7) 436).

71 Postacioğlu, Usul Hukuku (n 6) 479; Kuru, C. IV (n 8) 3550.

72 BeckOK ZPO/Elzer, ZPO $\$ 306$ (n 35) marg. 2; Bilge ve Önen (n 2) 350; Pekcanttez, Atalay ve Özekes, (n 34) 437; Atalı, Pekcanttez Usul (n 1) 2012; Muşul, (n 7) 436; Kuru, C. IV (n 8) 3551.

73 Kuru, C. IV (n 8) 3551.

74 Atalı, Ermenek ve Erdoğan (n 1) 572; Atalı, Pekcanıtez Usul (n 1) 2016; Karslı (n 1) 370; Muşul, (n 7) 436; Kuru, El Kitabı (n 8) 603; Yavuz (n 6) 1019.

75 ibid 603.

76 Atalı, Ermenek ve Erdoğan (n 1) 573; Karslı (n 1) 370. Kimi davalardan feragat edilmesi davayı sona erdirmeyecek; feragate rağmen yargılamaya devam edilmesi gerekecektir (Kuru, El Kitabı (n 8) 604).

77 Budak ve Karaaslan (n 1) N. 14, s. 306; Karslı (n 1) 370; Muşul, (n 7) 436.

78 Atal, Pekcanttez Usul (n 1) 2016-2017; Atalı, Ermenek ve Erdoğan (n 1) 573.

79 Budak ve Karaaslan (n 1) N. 14, s. 323; Atali, Pekcanitez Usul (n 1) 2018.

80 RG. 19.06.1932, S. 2128.

81 Kuru, El Kitabı (n 8) 604; Atalı, Ermenek ve Erdoğan (n 1) 575; Kuru, C. IV (n 8) 3568. “...iflasın külli bir tasfiye șekli olup açılmasının tüm alacaklılara etkili sonuçlar meydana getireceğinin tabii olması bir yana İIY’nın 165. Maddesine 24.11.1988 günü yürürlüğe giren 3494 sayll Yasa ile eklenen "iflas kararı verilmesinden sonra iflas davasından feragat geçersizdir" kuralı yasa koyucu da bu konudaki düşüncesini açıkça belirttiğinden delillerin değerlendirilmesinde bir isabetsizlik bulunmasına göre, yasaya uygun bulunan direnme kararının onanması gerekir" (Yarg. 11. HD, 19.11.1990, 12/497-545; Nihat İnal, Örnek Karar Dilekçelerle Açıklamalı Hukuk Yargılama Usulü Yasası (Yeni Yasa, 2012) 966). 
olmadığı belirtilerek hizmet tespiti talebiyle açılan davalardan feragatin geçerli olmayacağı kabul edilmektedir ${ }^{82}$. Yine, Yargıtay kararlarında, sigortalılık hakkından feragat edilemeyeceği gerekçesiyle davadan feragat yoluna gidilemeyeceği de ortaya konulmaktadır ${ }^{83}$. Bunların dışında, uygulamada, ortaklığın giderilmesi davasından da feragat edilemeyeceği kabul edilmektedir ${ }^{84}$. Ortaklığın giderilmesi davası çift taraflı bir dava (actio duplex) olduğu için, davacı tarafından davadan feragat edilirse, davalının davaya devam etmek istemesi durumunda, mahkeme, ortaklı̆̆ın giderilmesi davasına devam etmekle yükümlü olur ${ }^{85}$.

82 Atalı, Ermenek ve Erdoğan (n 1) 573; Atalı, Pekcantez Usul (n 1) 2017; Gençcan (n 34) 1068. Yargıtay 10. HD, 21.02.2005, E.2004/11796, K.2005/1483 “Belli bir sosyal güvenlik kuruluşu sigortalısı olmak, kamu düzenine ilişkin, kişiye bağlı, vazgeçilmez ve kaçınılmaz hak ve yükümlülük doğuran bir hukuksal statü yaratır. Sosyal güvenlik hakkından feragat mümkün olmadığından sigortalılı̆̆ın tespiti davasının feragat nedeniyle reddine karar verilemez. Davacı tespit davasından feragat edemeyeceğine göre, davasını geri alabilir, yani ileride tekrar dava açabilme hakkını saklı tutarak davanın takibinden vazgeçebilir. Mahkemece yapılacak iş; 506 sayılı Yasanın 6. maddesi uyarınca davadan feragatin mümkün olmayacağını davacıya hatırlatmak ve feragate ilişkin beyanı da hatırlatılarak, bunun davayı geri alma şeklinde anlaşılıp anlaşılamayacağı sorulmak ve Hukuk Usulü Muhakemeleri Kanununun 185 ve 409. maddesindeki prosedür gerekirse işletilmek üzere sonucuna göre karar vermekten ibarettir." (Kazancı İçtihat Bilgi Bankası); Yargıtay 10. HD, 26.11.2007, E.2174, K.19643 “...506 sayıl Yasa’nın 6. maddesi gereği sigortalı olmak hak ve yükümünden kaçınılamaz ve vazgeçilemez. Yasa’nın öngördüğü belli bir sosyal güvenlik kuruluşu sigortalısı olmak, kamu düzenine ilişkin, kişiye bağl, vazgeçilmez ve kaçınılmaz hak ve yükümlülük doğuran bir hukuksal statü yaratır. Kişi ve sosyal güvenlik kuruluşlarının bu statünün oluşumdaki rolü, yenilik doğurucu ve iradi bir durum değil, yasa gereği kendiliğinden meydana gelen statüyü belirlemekten ibarettir. Dolayısıyla sosyal güvenlik hakkından feragat mümkün olmadığından, feragat nedeniyle davanın reddine karar verilemez. Hal böyle olunca, davacı tespit davasından feragat edemeyeceğine göre, davasını geri alabilir. Başka bir anlatımla, ileride tekrar dava açabilme hakkın saklı tutan davanın takibinden vazgeçebilir. Mahkemece yapılacak iş; 506 sayılı Yasa’nın 6. maddesi uyarınca davadan feragatın mümkün olmayacağını davacıya hatırlatmak ve feragata ilişkin beyanı da hatırlatarak, bunun davayı geri alma şeklinde anlaşılıp anlaşılmayacağı sorulmak ve Hukuk Usulü Muhakemeleri Kanunu'nun 185 ve 409. maddesindeki prosedür gerekirse işletilmek üzere sonucuna göre karar vermekten ibarettir." (Kazancı İçtihat Bilgi Bankası); Yargıtay 21. HD, 16.10.2000, E. 2000/5015, K.2000/6907 "Davacı, davalılardan köy muhtarlı̆̆ nezdinde 1.1.1986-3.12.1999 tarihleri arasında sigortalı olarak çalıştığının tesbitine karar verilmesini istemiştir. Mahkeme, ilamında belirtildiği şekilde feragat nedeniyle reddine karar vermiştir. Hükmün, davalı vekili tarafindan temyiz edilmesi üzerine, temyiz isteğinin süresinde olduğu anlaşıldıktan ve tetkik hakimi tarafindan düzenlenen raporla dosyadaki kağıtlar okunduktan sonra işin gereği düşünüldü ve aşă̆ıdaki karar tesbit edildi." (Kazancı İçtihat Bilgi Bankası); Yargıtay 10. HD, 05.10.2012, E.16553, K.17570 “Dava, Tarım Bă̆-Kur Sigortalılı̆̆ının ve 6111 S.K. Kapsamında yapılandırmadan yararlandırılmasının tespiti istemine ilişkindir. Davacı vekili, vekaletnamesindeki feragat yetkisini kullanarak davadan feragat dilekçesi sunmuştur. Anayasa'da ve 2926 S.K.'da sigortalı olmanın kamu düzenine ilişkin, kişiye bağl, vazgeçilemez ve kaçınılamaz hak ve yükümlülük doğuran bir hukuksal statü meydana getirdiği, kişilerin ve sosyal güvenlik kuruluşlarının bu statünün oluşumundaki rolünün yenilik doğurucu ve iradi bir durum değil, kanun gereği kendiliğinden oluşan statüyü belirlemekten ibaret olduğu ifade edilmiştir. Bu tür davalardan feragat olanaksızdır ve açılan sigortalılı̆̆ın ve sigortalı hizmetlerin tespitine ilişkin davadan da vazgeçilemez. Davacı ancak, ileride yeniden dava açabilme hakkını saklı tutarak, davalının rızası ile, davanın takibinden vazgeçebilir veya davayı takip etmeyerek yenileninceye kadar dosyanın işlemden kaldırılması ve giderek davanın açılmamış sayılması sonucunu elde edebilir.” (Kazancı İçtihat Bilgi Bankası).

83 Yarg. HGK. 11.2.2004, 54/54, “....sigortalllk hakkından feragat edilemez. Kamu düzenini ilgilendiren bu tür tesbit davalarında hakimin feragat nedeniyle davayı reddetmeyip özel bir duyarlılı göstererek delilleri kendiliğinden toplaması ve sonucuna göre karar vermesi gerekir" (YKD 2004/6, s. 835; Alangoya, Yıldırım ve Deren-Yıldırım, Esaslar (n 1) 423, dn. 5a).

84 Atalı, Pekcantez Usul (n 1) 2017; Atalı, Ermenek ve Erdoğan (n 1) 573; Budak ve Karaaslan (n 1) N. 14, s. 323.

85 Kuru, El Kitabı (n 8) 604. Yargıtay’a göre, ortaklığın (paydaşlığın) giderilmesi davalarında, davacı davasından feragat etse bile, davalılardan birinin davaya devam etmek istemesi halinde mahkemece davaya devam edilmesi gerektiği içtihat edilmektedir. Yarg. 14. HD, 28.12.2916, E. 2015/11612, K. 2016/10954 “...Paydaşlı̆̆ın (ortaklı̆̆ın) giderilmesi davaları iki taraflı, taraflar için benzer sonuçlar doğuran davalardır. Bu davalarda davalı da davacı gibi aynı haklara sahiptir. Bu nedenle davacının paydaşlığın satış suretiyle giderilmesini istemesi davalıların aynen paylaşma istemesine engel teşkil etmez. Davacı davasindan feragat etse bile davalılardan birinin davaya devam etmek istemesi halinde mahkemece davaya devam edilerek işin esası hakkında karar verilmelidir. Bu nedenle davacının davadan feragat beyanına karşı hazır bulunan davalilardan diyecekleri sorulmal, davaya devam etmeyi istemeleri halinde yargllamaya devam edilmelidir. Somut 


\section{B. DAVADAN FERAGATIN HUKUKI NITELIĞi}

Davadan feragatin hukuki niteliği konusunda doktrinde birbirinden farklı görüşler ileri sürülmektedir ${ }^{86}$. Davadan feragatin hukuki niteliğine ilişkin olarak doktrinde ileri sürülen görüşleri üç grupta toplamak mümkündür ${ }^{87}$. Buna göre, doktrinde, davadan feragatin "salt bir maddi hukuk işlemi olduğu", "salt bir usul hukuku işlemi olduğu” ve "karma karakterli bir işlem olduğu” şeklinde üç görüş ileri sürülmektedir ${ }^{88}$.

Kanaatimizce açılmış ve görülmekte olan bir davadan feragat yoluna gidilmesi ile hem bir usulî işlem hem de bir maddi hukuk işlemi yapılmış olmaktadır ${ }^{89}$. Zira, davadan feragat ile bir taraftan, davaya konu olan haktan feragat edildiği için maddi hukuka ilişkin bir işlem gerçekleştirilmektedir ${ }^{90}$. Diğer taraftan ise, davadan feragat ile aynı zamanda bir usulî işlem yapılmaktadır ${ }^{91}$. Davadan feragatin yapılış biçimi ile feragat neticesinde uyuşmazlığın sona ermesi, onun usulî işlem olan niteliğini ortaya koymaktadır $^{92}$. Bütün bu açıklamalarımız üzerine, belirtmek isteriz ki, davadan feragatin hukuki niteliğinin "karma karakterli bir işlem” olduğunu kabul etmek kanaatimizce daha uygun olacaktır ${ }^{93}$.

Davadan feragatin hukuki niteliğinin karma karakterli bir işlem olduğunun kabul edilmesinin neticesinde, davac1, davadan feragat etmekle hem bir usulî işlem yapmakta hem de dilekçesinin talep sonucu bölümünde yer alan haktan feragat etmek suretiyle maddi hukuka ilişkin bir işlem gerçekleştirmiş olmaktadır ${ }^{94}$.

\section{DAVADAN FERAGATIN ŞEKLi}

Davadan feragatin etkisini doğurabilmesi için kanunda öngörülen şekle riayet edilmesi gerekmektedir ${ }^{95}$. Davadan feragat konusunda getirilen şekle ilişkin kurallar aynı zamanda geçerlilik

olaya gelince; davacılar vekilinin 15.12.2016 tarihli dilekçesi ile davadan feragat ettiği ancak dosyada davacılar vekilinin vekaletnamesinin bulunmadığı anlaşılmıştır. O halde, öncelikle davacılar vekilinin vekaletnamesinin temin edilerek davadan feragat yetkisinin bulunup bulunmadığı tespit edildikten sonra yukarıda değinilen ilkeler gözetilmek suretiyle bir karar verilmek üzere hükmün bozulması gerekmiştir..." (e-uyar). davadan feragat edilebilmesi için gerekli olan șartlar ile feragatin etkileri medeni usul hukuku alanında düzenlenmektedir (Kuru, C. IV (n 8) 3545; Kuru, İstinaf Sistemi (n 7) 387). Bu doğrultuda, davadan feragatin şekli (m. 309), zamanı (m. 310), sonuçları (m. 311) ile feragat halinde mahkemece tayin edilecek olan yargılama giderleri (m. 312) Hukuk Muhakemeleri Kanununda yer almaktadır (Kuru, İstinaf Sistemi (n 7) 387).

92 Kuru, İstinaf Sistemi (n 7) 387; Kuru, C. IV (n 8) 3545.

93 Atalı, Pekcanıtez Usul (n 1) 2011. Davadan feragatin çifte karakterli hukuki işlem olduğu hakkında bkz.: Budak ve Karaaslan (n 1) N. 3, s. 319; Akyol Aslan (n 2) 193.

94 Kuru, İstinaf Sistemi (n 7) 387; Kuru, C. IV (n 8) 3545.

95 Kuru, Arslan ve Yilmaz, Medeni Usul (n 1) 506. 
şartıdır ${ }^{96}$. Bu sebeple, şekil bakımından kanun koyucu tarafından öngörülen şartlara riayet edilmeden yapılan feragat beyanı geçerli olmayacaktır ${ }^{97}$.

Davadan feragatin şekli, Hukuk Muhakemeleri Kanunu'nun 309'uncu maddesinde açıkça düzenlenmektedir ${ }^{98}$. Hukuk Muhakemeleri Kanunu'nun 309'uncu maddesinin 1'inci fikrasına göre, davadan feragat, "dilekçeyle" veya yargılamanın devam ettiği esnada "sözlü olarak" gerçekleştirilebilecektir99. Görüldügü üzere, davadan feragatin, “yazılı olarak” (dilekçeyle) yapılabileceği Kanun'da açıçca düzenlenmektedir ${ }^{100}$. Davadan feragatin yazılı olarak yapılması durumunda, feragat iradesinin geçerli bir şekilde ortaya konulduğundan söz edebilmek için, mahkemeye sunulan feragat beyanının ayrıca duruşma tutanağına geçirilmesine ve davacıya imzalattırılmasına gerek yoktur ${ }^{101}$. Böyle bir durumda, davacının davadan feragat ettiğine dair dilekçesinin mahkemeye verildiğine ve yargılama dosyasına eklendiğine dair bir açıklamanın tutanağa geçirilmesi yeterli olur ${ }^{102}$ (HMK m. 154/f. 4).

Davadan feragat, davacının yargılama sırasında "sözlü" olarak iradesini ortaya koyması yoluyla da gerçekleştirilebilir ${ }^{103}$. Böyle bir durumda, feragat beyanı, mahkeme huzurunda duruşmaların görüldüğü bir esnada yapılabileceği gibi keşif vb. gibi yargılama işlemleri sırasında sözlü bir şekilde de gerçekleştirilebilir ${ }^{104}$. Davadan feragatin sözlü olarak yapılması durumunda, - dilekçeyle yapılmasından farklı olarak - davacının feragat beyanının açıkça duruşma tutanağına yazılması ve

96 Kuru, El Kitabı (n 8) 599.

97 Kuru, Arslan ve Yılmaz, Medeni Usul (n 1) 506.

98 Atalı, Ermenek ve Erdoğan (n 1) 574. Hukuk Muhakemeleri Kanunu'nun "Feragat ve kabulün şekli” kenar başlıklı 309'uncu maddesinde davadan feragatin şekli şu şekilde ifade edilmektedir:

“(1) Feragat ve kabul, dilekçeyle veya yargılama sırasında sözlü olarak yapılır. (2) Feragat ve kabulün hüküm ifade etmesi, karşı tarafin ve mahkemenin muvafakatine bağlı değildir. (3) Kısmen feragat veya kabulde, feragat edilen veya kabul edilen kısmın, dilekçede yahut tutanakta açıkça gösterilmesi gerekir. (4) Feragat ve kabul, kayıtsız ve şartsız olmalıdır”. Hukuk Muhakemeleri Kanunu'nda feragatin şekline ilişsin düzenlemenin yürürlükten kaldırılan 1086 sayılı Hukuk Usulü Muhakemeleri Kanunu'ndaki karşılığı HUMK m. 93’te yer almaktaydı. Kanun koyucu eskiden uygulanmakta olan HUMK m. 93'te bu hususa ilişkin olarak şu şekilde bir düzenleme getirmekteydi: “Feragat ve kabul beyanı dilekçe ile veya yargılama sırasında sözlü olarak yapılır. Görüldüğü üzere, 6100 sayılı HMK m. 309 hükmünde feragatin şekline ilişkin olarak HUMK m. 93’te öngörülene kıyasla daha kapsamlı bir düzenleme getirilmiştir.

99 Davadan feragatin dilekçeyle (yani yazılı) veya sözlü olarak yapılabileceği hakkında bkz.: Atalı, Pekcanıtez Usul (n 1) 2019; Kuru, Arslan ve Yılmaz, Medeni Usul (n 1) 506; Atalı, Ermenek ve Erdoğan (n 1) 574; Karslı (n 1) 372; Budak ve Karaaslan (n 1) N. 12, s. 322; Muşul, (n 7) 441; Kuru, El Kitabı (n 8) 599.

100 Dilekçeyle davdan feragat hakkında bkz.: Kuru, Arslan ve Yılmaz, Medeni Usul (n 1) 506-507.

101 Karslı (n 1) 372; Kuru, Arslan ve Yılmaz, Medeni Usul (n 1) 506; Akyol Aslan (n 2) 246.

102 Kuru, Arslan ve Yılmaz, Medeni Usul (n 1) 507; Karslı (n 1) 372. Hukuk Muhakemeleri Kanunu'nun 154'üncü maddesinin 4’üncü fikrası uyarınca, tutanakta sözü edilen veya dosyaya konduğu belirtilen belgeler de tutanağın eki sayılacağ öngörüldügü için, feragatin yazılı yapıldığı durumlarda dilekçenin mahkemeye sunulduğunun tutanağa geçirildiğine dair bir açlklamaya yer verilmesi yeterli olacaktır.

103 Kuru, Arslan ve Yilmaz, Medeni Usul (n 1) 506; Bilge ve Önen (n 2) 351; Bilge (n 2) 309.

104 Atalı, Pekcantez Usul (n 1) 2019; Kuru, Arslan ve Yılmaz, Medeni Usul (n 1) 506; Görgün, Börü, Toraman ve Kodakoğlu (n 6) 595. Davadan feragat, mahkemece gerçekleştirilen keşif esnasında yapılabilecektir. Keşif esnasında davadan feragat edilmesi durumunda, davacının feragata ilişkin iradesinin, keşif tutanağına yazılarak altının davacıya imzalattırılması gerekmektedir (Görgün, Börü, Toraman ve Kodakoğlu (n 6) 595). Yargitay'ın da keşif esnasında davadan feragat edilmesi durumuna ilişkin bir kararı söz konusudur. Yarg. 8. HD, 3.12.2003, 7809/7997 (Ejder Yılmaz, Hukuk Muhakemeleri Kanunu Şerhi (2. Bası, Yetkin 2013) 1366). 
tutanağın altının davacı tarafa imzalattırılması gerekmektedir ${ }^{105}$ (HMK m. 154/f. 3, ç). Davadan feragat iradesinin tutanağa yazılarak davacıya imzalattırılması sözlü olarak yapılan feragat talebi bakımından bir geçerlilik şartıdır ${ }^{106}$.

Davadan feragat edilebilmesi için karşı tarafın iznine veya yargılamayı gerçekleştirecek olan hâkimin muvafakatine gerek bulunmamaktadır ${ }^{107}$. 1086 sayılı Hukuk Usulü Muhakemeleri Kanunu’nda bu hususa ilişkin olarak bir düzenleme getirilmiş değildi ${ }^{108}$. Bununla birlikte, gerek Yargıtay kararlarında $^{109}$ gerekse de doktrinde ${ }^{110}$ davadan feragat edilebilmesi için karşı tarafın iznine veya

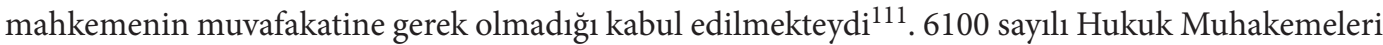
Kanunu'nda ise, bu konuya ilişkin olarak açık bir düzenleme getirilmiştir. Buna göre, Hukuk Muhakemeleri Kanunu'nun 309'uncu maddesinin 2'nci fikrasinda, "Feragat ve kabulün hüküm ifade etmesi, karşı tarafin ve mahkemenin muvafakatine bağlı değildir” denilmektedir ${ }^{112}$. Feragatin söz konusu olabilmesi için davalının iznine ihtiyaç olmadığından ${ }^{113}$ (HMK m. 309/f. 2) davadan geçerli bir şekilde feragat edilebilmesi için davalının o yargılamada hazır bulunması şart değildir ${ }^{114}$.

Davadan feragat sadece mahkeme huzurunda değil; aynı zamanda, mahkeme dışında da yapılabilir ${ }^{115}$. Mahkeme dışında yapılan feragatin, sonradan yargılamayı yürüten hâkimin huzurunda ya da mahkemeye iletilecek olan bir dilekçede açıkça kabul edilmesi gerekmektedir ${ }^{116}$. Aksi takdirde, davacı

105 Kuru, Arslan ve Yllmaz, Medeni Usul (n 1) 506; Bilge ve Önen (n 2) 351; Karslı (n 1) 372; Atalı, Pekcanitez Usul (n 1) 2019; Atalı, Ermenek ve Erdoğan (n 1) 574. Hukuk Muhakemeleri Kanunu’nun 154'üncü maddesinin 3’üncü fikrasında duruşma tutanağına mutlak olarak yazılması gereken hususlar belirtilmiştir. Buna göre, bahsi geçen HMK m. 154/f. 3, ç hükmünde, "Beyanda bulunana okunmak ve imzası alınmak kaydıyla ikrar, yeminin edası, davanın geri alınmasına muvafakat, davadan feragat, davayı kabule ilişkin beyanlar ve sulh müzakereleri ile sonucu"nun mutlak olarak tutanağa yazılacağ 1 ifade edilmiştir.

106 Kuru, Arslan ve Yılmaz, Medeni Usul (n 1) 506; Atal,, Ermenek ve Erdoğan (n 1) 574.

107 Alangoya, Ylldırım ve Deren-Ylldırım, Esaslar (n 1) 422-423; Karslı (n 1) 373; Atalı, Pekcanitez Usul (n 1) 2016; Atalı, Ermenek ve Erdoğan (n 1) 574; Kuru, Arslan ve Yılmaz, Medeni Usul (n 1) 505; Muşul, (n 7) 437, 441; Kuru, İstinaf Sistemi (n 7) 389; Görgün, Börü, Toraman ve Kodakoğlu (n 6) 596; Akyol Aslan (n 2$) 127$.

108 Akyol Aslan (n 2) 250.

109 Yarg. 3. HD, 24.4.1979, 2757/2821 “...Vazgeçme kesin hükmün sonuçlarını doğurur. Bunun için ayrıca karar verilmesi ve vazgeçmeyi karşı tarafin kabulü gerekmez...” (YKD 1979/10, s. 1415). Yarg. 2. HD, 21.3.1985, 2487/2698 “...Davadan feragat davalını kabulüne bağl değildir. Öyle ise davacı ...nin davasının vazgeçme sebebiyle reddi gerekirken, davacının delillerini değerlendirip boşanmaya hükmedilmesi usul ve kanuna aykırıdır..." (IKİD 1988/331, s. 5819; Aynı karar için bkz.: Akyol Aslan (n 2) 129, dn. 298).

110 Postacıoğlu, Usul Hukuku (n 6) 480; Ansay (n 6) 180; Necmettin M Berkin, Tatbikaţ̧ılara Medeni Usul Hukuku Rehberi (Filiz Kitabevi 1982) 709; Üstündağ (n 6) 571; Ergun Önen, Medeni Yargılama Hukuku (Sevinç Matbaas1, 1979) 279; Önen, 'Feragat' (n 5) 28; Bilge ve Önen (n 2) 351; Mustafa Reşit Belgesay, Hukuk Usulü Muhakemeleri Kanunu Şerhi I Teoriler (3. Bası, Duygu Matbaası 1948) 194; Şakir Berki, Hukuk Muhakemeleri Usulü (Ege 1959) 28; Soner (n 11) 446; Akyol Aslan (n 2) $127 \mathrm{vd}$.

111 Alangoya, Yıldırım ve Deren-Yıldırım, Esaslar (n 1) 425; Karslı (n 1) 373; Akyol Aslan (n 2) 127.

112 Karslı (n 1) 373. Davadan feragat beyanı, iddia ve savunmanın genişletilmesi ve değiştirilmesi yasağına (HMK m. 141) da tabi olmaz (Atalı, Pekcantez Usul (n 1) 2016).

113 Alangoya, Ylldırım ve Deren-Ylldırım, Esaslar (n 1) 422-423; Karslı (n 1) 373; Atalı, Pekcanitez Usul (n 1) 2016; Atalı, Ermenek ve Erdoğan (n 1) 574; Kuru, Arslan ve Yllmaz, Medeni Usul (n 1) 505; Muşul, (n 7) 437, 441; Kuru, İstinaf Sistemi (n 7) 389; Görgün, Börü, Toraman ve Kodakoğlu (n 6) 596.

114 Karslı (n 1) 373.

115 Bilge ve Önen (n 2) 351; Kuru, El Kitabı (n 8) 604.

116 Görgün, Börü, Toraman ve Kodakoğlu (n 6) 595; Ayrıca, Umar, mahkeme dışında yapılan feragat bakımından feragat 
tarafından bu şekilde açıkça kabul edilmeyen bir feragat beyanının geçerli bir şekilde yapıldığından söz edilemez ${ }^{117}$.

Davacı, davadan feragat beyanını içeren dilekçeyi, yargılamayı gerçekleştiren mahkemeye posta ile gönderebilir ${ }^{118}$. Böyle bir durumda, davadan feragat dilekçesinde yer alan imzanın davacının kendisine ait olduğuna dair noter şerhinin bulunması gerekmektedir ${ }^{119}$. Davadan feragat dilekçesinin posta ile mahkemeye gönderilmesi ihtimalinde, imzanın davacıya ait olduğu konusunda bir noter şerhi yer almıyorsa, mahkemenin davacıyı isticvap ederek imzanın kendisine ait olup olmadığı hususunu tespit etmesi gerekir ${ }^{120}$.

Davacı, dava konusunun gerek bir kısmından gerekse de tamamından feragat edebilir ${ }^{121}$. Dava konusunun bir kısmından feragat edilebilmesi için, feragat edilmek istenen kısmın ayrılabilir ve bağımsız olması gerekmektedir ${ }^{122}$. Aynı zamanda, yargılamanın sonunda mahkemece kısmî hüküm verilebilmesi de mümkün olmalıdır ${ }^{123}$. Davacının talep sonucunun bir kısmından feragat etmesi durumunda, Hukuk Muhakemeleri Kanunu'nun 309'uncu maddesinin 3'üncü fikrasinda öngörülen düzenleme uyarınca, feragat edilen kısmın dilekçede yahut tutanakta açıkça gösterilmesi gerekmektedir $^{124}$. Davadan kismen feragat edilmesi durumunda, netice-i talebin feragat edilmeyen kısmı için davaya devam edilir ${ }^{125}$. Bununla birlikte, davacının feragat ettiği kısım için dava sona $\operatorname{erer}^{126}$.

dilekçesinin hasma tebliğ edilmesinin gerektiğinden söz etmektedir. Bkz.: Bilge Umar, Hukuk Muhakemeleri Kanunu Şerhi (Yargıı̧ ve Avukatlar İçin HMK Uygulamasında Karşılaşılacak Soru ve Sorunların Türk ve Neuchâtel Bilimsel ve Yargısal İçtihatları Işığında Yanıtları ve Çözümleri) (2. Bası, Yetkin 2014) 907. Yarg. 3. HD, 22.06.2010, E. 2010/10367, K. 2010/11157 “...Davacının talep sonucundan vazgeçmesidir. Davadan feragat, davacının mahkemeye karşı yapacağı tek tarafl bir irade beyan ile olur. Feragat beyanının açık olması çok önemlidir. Feragat, duruşma sırasında sözlü olarak yapılabileceği gibi, davacı duruşma sırasında mahkemeye vereceği bir dilekçe ile de davasından feragat edebilir. Diğer yandan, duruşma dışında da mahkemeye verilecek dilekçe ile de feragat mümkündür. Ancak bu durumda hâkim tarafindan feragat dilekçesinin altına imzanın davacıya ya da yetkili vekiline ait olduğu yolunda şerh verilmesi gerekir. Bu şekilde usulünce yapılan feragat ile dava konusu uyuşmazlik da son bulmuş olur. Somut olayda, davacının, davalının tarafolmadı̆̆ adi yazılı belgedeki genel ifadeli beyan esas alnarak mahkemece feragat nedeni ile ret kararı verilmiştir..." (Lexpera).

117 Atali, Pekcanttez Usul (n 1) 2019.

118 Akyol Aslan (n 2) 248-249; Kuru, C. IV (n 8) 3611; Karslı (n 1) 372.

119 Akyol Aslan (n 2) 248-249; Karslı (n 1) 372; Kuru, C. IV (n 8) 3611. Zira, aksi takdirde, davacı yerine başka bir üçüncü şahsın feragat beyanını aldatııı bir şekilde ileri sürerek davayı sona erdirme ihtimali olabilecektir. Bu sebeple, davadan feragat dilekçesinin davacının mahkeme huzurunda yer almadığı posta ile gönderilmesi yolunda yargılamayı gerçekleştiren mahkemece dikkatli olunması ve iyi bir şekilde incelenmesi gerekmektedir (Akyol Aslan (n 2) 248-249; Karsli (n 1) 372).

120 Kuru, C. IV (n 8) 3611. Kendisine gönderilen isticvap dilekçesine rağmen davacı mahkeme huzuruna gelmezse ya da mahkemeye gelmekle birlikte herhangi bir cevap vermezse, feragat dilekçesinin altındaki imzanın kendisine ait olduğu hususunu ikrar etmiş sayılacaktır (Kuru, C. IV (n 8) 3611).

121 Ansay (n 6) 180; Bilge ve Önen (n 2) 352; Postacioğlu, Usul Hukuku (n 6) 480; Kuru, Arslan ve Yllmaz, Medeni Usul (n 1) 506; Karslı (n 1) 373; Akyol Aslan (n 2) 130.

122 Akyol Aslan (n 2) 129-130; Karslı (n 1) 373. Davada konusunun bir kısmından feragatte davacı, aynı hukuki ilişkinin bütünlük gösteren netice-i talebinin bir kısmından feragat etmektedir (Akyol Aslan (n 2) 130; Karslı (n 1) 373).

123 Akyol Aslan (n 2) 129-130; Karsli (n 1) 373.

124 Atalı, Ermenek ve Erdoğan (n 1) 574; Karslı (n 1) 373; Budak ve Karaaslan (n 1) N. 12, s. 322.

125 Akyol Aslan (n 2) 130; Kuru, Arslan ve Yllmaz, Medeni Usul (n 1) 506.

126 Kuru, Arslan ve Yilmaz, Medeni Usul (n 1) 506; Akyol Aslan (n 2) 130; Karslı (n 1$) 373$. 
Davadan feragat, Hukuk Muhakemeleri Kanunu'nun 309'uncu maddesinin 4’üncü fikrası uyarınca "kayıtsız ve şartsız" yapılmalıdır ${ }^{127}$. Bununla birlikte, 1086 sayılı Hukuk Usulü Muhakemeleri Kanunu zamanında davadan feragatin şarta bağlı olarak yapılıp yapılamayacağı hususu açıkça düzenlenmediğinden, doktrinde şarta bağlı olarak yapılan feragat beyanının geçerliliği meselesi tartışma konusu yapılmaktaydı ${ }^{128}$. Diğer taraftan, Hukuk Muhakemeleri Kanunu'nda, feragatin şarta bağlı olarak yapılamayacağı açıkça öngörüldüğünden, bu konudaki tartışmalar da sona ermiştir ${ }^{129}$. Şarta bağlı feragat, davacının tek taraflı bir irade beyanıyla davayı sona erdirmesi ve aynı zamanda, feragatin kesin hüküm gibi hukuki sonuçlarının (HMK m. 311) olması sebebiyle yasaklanmıştır ${ }^{130}$. Hukuk Muhakemeleri Kanunu’na göre, feragatin şarta bağlı olarak yapılabileceği kabul edilmediğinden, doktrinde şartın gerçekleşmesi durumunda, davadan feragat edileceğini öngören bir beyan "sulh teklifi" olarak nitelendirilmektedir"131.

Davadan feragat beyanının ileri sürüldüğü mahkemenin yetkisiz olması durumunda, mahkemece öncelikle yetkisizlik kararının mı verileceği, yoksa feragat konusundaki incelemenin mi gerçekleştirileceği sorusunun cevaplandırılması önem arz etmektedir. Bu konuda, doktrinde ileri sürülen bir görüşe göre, yetkisiz mahkemeye hitaben davadan feragat beyanında bulunulması üzerine davalı tarafından yetkisizlik itirazında bulunulacağı ve mahkemenin gerçekten yetkisiz olduğunun anlaşılması halinde dahi yetkisizlik kararından önce mahkemenin davanın feragat sebebiyle sona erdiğine karar vermesinin gerekeceği ifade edilmektedir ${ }^{132}$. Diğer taraftan, Yargıtay kararlarında,

127 Pekcanıtez, Atalay ve Özekes, (n 34) 438; Atalı, Pekcanttez Usul (n 1) 2019; Kuru, Arslan ve Yilmaz, Medeni Usul (n 1) 506; Budak ve Karaaslan (n 1) N. 12, s. 322; Atalı, Ermenek ve Erdoğan (n 1) 574; Karslı (n 1) 373.

128 Karslı (n 1) 372. 1086 sayılı Hukuk Muhakemeleri Kanunu zamanında, şarta bağlı olarak feragat yapılıp yapılamayacağı konusunda, iki farklı görüş ileri sürülmekteydi. Doktrinde ileri sürülen bir görüşe göre, davadan feragatin şarta bağlı olarak yapılması mümkündür (Belgesay (n 110) 300 vd.; İlhan E. Postacıoğlu, 'Şarta Muallâk Hükümler' (1941) 2 Adalet Dergisi 113-114; Süha Tanrıver, 'Şarta Bağlı Hüküm Kavramı ve Verilip Verilemeyeceği Sorunu' (1988) 19 (4) Banka ve Ticaret Hukuku Dergisi 48 vd.). Doktrinde ileri sürülen aksi yöndeki diğer görüşe göre, davadan feragat, şarta bağlı olarak gerçekleştirilemeyecektir (Üstündağ (n 6) 573; Berkin (n 110) 711; Ansay (n 6) 180; Bilge ve Önen (n 2) 351; Akyol Aslan (n 2) 133). 1086 sayılı Hukuk Usulü Muhakemeleri Kanun zamanında, doktrinde ağırlıklı olan görüş, feragatin şarta bağlı olarak yapılamayacağı yönündeydi (Üstündağ (n 6) 573; Berkin (n 110) 711; Ansay (n 6) 180; Bilge ve Önen (n 2) 351; Akyol Aslan (n 2) 133).

129 Karslı (n 1) 373.

130 Nuray Sümer, 'Şartlı Feragata İlişkin Danıştay Kararlarının Düşündürdükleri' (2018) 2 Galatasaray Üniversitesi Hukuk Fakültesi Dergisi 276.

131 Kuru, Arslan ve Yılmaz, Medeni Usul (n 1) 506; Kuru, C. IV (n 8) 3584; Pekcanitez, Atalay ve Özekes, (n 34) 438; Atalı, Pekcanitez Usul (n 1) 2019; Budak ve Karaaslan (n 1) N. 12, s. 322; Sümer (n 130) 278. Görüldüğü üzere, şarta bağlı feragat beyanı doğrudan reddedilmemektedir. Böyle bir durumda, şarta bağlı feragat beyanı nitelik değiştirerek sulh anlaşmasına dönüşebilmektedir (Sümer (n 130) 278).

132 Kuru, C. IV (n 8) 3587. Bununla birlikte, doktrinde bazı yazarlarca, konu değerlendirilirken mahkemesinin yetkisinin kesin yetki olup olmadığı hususu dikkate alınarak farklı görüşlerin ileri sürüldüğü de ifade edilebilecektir. Buna göre, davanın görülmekte olduğu mahkemenin yetkisinin kesin olduğu hallerde, yetkisiz bir mahkemede davanın açılması durumunda, davadan feragat üzerine mahkemece yetkisizlik kararı verilerek feragat hakkında yetkili mahkemenin karar vermesi sağlanmalıdır (Umar (n 116) 909; Yılmaz (n 104) 1367; Görgün, Börü, Toraman ve Kodakoğlu (n 6) 595). Bununla birlikte, yetkinin kesin olmadığı hallerde, aynı zamanda, davalı HMK m. 19/f. 2 uyarınca cevap dilekçesinde yetki itirazında bulunmamıssa davanın feragat nedeniyle sona erdiğini tespit eden bir karar verilerek yargılama sona erdirilmelidir (Umar (n 116) 909; Görgün, Börü, Toraman ve Kodakoğlu (n 6) 595). Davalı tarafindan, mahkemenin yetkisiz olduğunun ileri sürülmesi durumunda, yetkisiz mahkemeye yapılan feragat geçerli sayılarak, davanın feragat nedeniyle sona erdiğine karar verilmesi gerekir (Görgün, Börü, Toraman ve Kodakoğlu (n 6) 595). 
yetkisiz mahkemenin feragat sebebiyle davanın sona erdiğine karar veremeyeceği; öncelikle, yetki itirazını inceleyerek bu hususta bir karar vermesinin gerektiği hükme bağlanmaktadır ${ }^{133}$. Kanaatimizce, davalı tarafından mahkemenin yetkisizliği ileri sürülmüşken aynı zamanda davacının feragat bayanı mevcut ise, yetki uyuşmazlığı incelenerek bir karar verilmeden davadan feragat konusunda hüküm tesis edilmesi uygun olmaz ${ }^{134}$. Diğer bir ifadeyle, öncelikle, yetki konusundaki uyuşmazlığın giderilerek dosyanın yetkili mahkemeye gönderilmesi sağlanmalıdır ${ }^{135}$. Sonrasında ise, yetkili mahkemece davanın feragat sebebiyle sona erdiğine dair bir karar verilmesi söz konusu olmalıdır ${ }^{136}$.

Davadan feragatin vekil tarafından yapılabilmesi için, vekilin vekaletnamesinde özel bir yetkiye sahip olması gerekmektedir ${ }^{137}$. Zira, Hukuk Muhakemeleri Kanunu'nun 74'üncü maddesine göre, davadan feragat, vekilin vekaletnamesinde özel yetki bulunmasını gerektiren hallerden birisidir ${ }^{138}$. Bu sebeple, davacı, kendisini vekil ile temsil ettirmeyi tercih etmişse, davadan feragat iradesini vekil aracılığıyla ileri sürülebilmesi için, vekilin vekaletnamesinde özel bir yetkinin bulunması şarttır ${ }^{139}$.

Gerçek kişilerin velisi veya bir tüzel kişinin organının, davadan feragat edebilmek için herhangi bir makamdan izin alması zorunlu değildir ${ }^{140}$. Bununla birlikte, vasinin sulh beyanını ileri sürebilmesi

133 Atalı, Pekcanitez Usul (n 1) 2011. Yarg. 2. HD, 10.12.1973, 7498/7091 “...Davalı süresinde yetki itirazında bulunmuş, davacı ise davasından vazgeçmiştir. Yetki itirazı iptidai itirazlardan olup, her şeyden önce bu hususun hadise şeklinde incelenmesi lazım gelir (HUMK m. 190, 225). Yetki uyuşmazliğı çözülmedikçe feragat sebebiyle hüküm tesis edilemez. Feragat sebebiyle dava ancak yetkili mahkemece karara bağlanabilir...”. (IBD 1974/1-4, s. 214; Kuru, C. IV (n 8) 3587). Yarg. 2. HD, 21.05.2012, 6798/13707 “...Davalı süresinde yetki itirazında bulunmuş davacı ise davadan feragat etmiştir. Yetki itirazı ilk itirazlardan olup her şeyden önce bu hususun hadise şeklinde incelenmesi lazım gelir (HMK m. 116-130). Yetki uyuşmazlığı çözülmedikçe feragat sebebiyle dava ancak yetkili mahkemece karara bağlanabilir...” (MİHDER 2014/2, S. 28, s. 113-114; Aynı karar için bkz.: Atalı, Pekcanitez Usul (n 1) 2011).

134 Aksi görüşste bkz.: Kuru, C. IV (n 8) 3587 vd.; Kudret Aslan, Medeni Usul Hukukunda Davadan Feragat (Yayımlanmamış Yüksek Lisans Tezi, 1999) 28-29; Akyol Aslan (n 2) 223-224.

135 Doktrinde aksi görüşteki Akyol Aslan’a göre, mahkemece yetkisizlik kararı verilerek dosyanın yetkili mahkemeye gönderilmesinden sonra feragat konusunda karar verileceğinin kabul edilmesi, gereksiz zaman kaybına ve gider yapılmasına sebep olacağı için isabetli değildir (Akyol Aslan (n 2) 224).

136 Doktrinde, Akyol Aslan, davadan feragat konusunda yetkisiz mahkeme ile yetkili mahkemenin bu anlamda aynı işi yaptığını ileri sürerek davadan feragat hakkında yetkili mahkemece karar verilmesi gerektiği yönündeki görüşü eleştirmektedir. Yazar, aynı zamanda, davanın feragat sebebiyle sona erdiğine yönelik tespitin yetkili mahkemece gerçekleştirilmesinde tarafların da menfaatinin söz konusu olmayacağını ifade etmektedir (Akyol Aslan (n 2) 224).

137 Postacioğlu, Usul Hukuku (n 6) 480; Bilge ve Önen (n 2) 352; Kuru, El Kitabı C. 2 (n 6) 1048-1049.

138 Hukuk Muhakemeleri Kanunu'nun 74'üncü maddesinde davaya vekalette vekile özel yetki verilmesini gerektiren haller açıkça ifade edilmektedir. HMK'nın 74'üncü maddesinde öngörülen düzenleme uyarınca, “Açıç̧a yetki verilmemiş ise vekil; sulh olamaz, hâkimi reddedemez, davanın tamamın ıslah edemez, yemin teklif edemez, yemini kabul, iade veya reddedemez, başkasın tevkil edemez, haczi kaldıramaz, müvekkilinin iflasını isteyemez, tahkim ve hakem sözleşmesi yapamaz, konkordato veya sermaye şirketleri ve kooperatiflerin uzlaşma yoluyla yeniden yapılandırılması teklifinde bulunamaz ve bunlara muvafakat veremez, alternatif uyuşmazlık çözüm yollarına başvuramaz, davadan veya kanun yollarından feragat edemez, karşı tarafı ibra ve davasını kabul edemez, yargılamanın iadesi yoluna gidemez, hâkimlerin fiilleri sebebiyle Devlet aleyhine tazminat davası açamaz, hangileri hakkında yetki verildiği açıklanmadıkça kişiye sıkı sıkıya bağlı haklarla ilgili davaları açamaz ve takip edemez." denilmektedir. Görüldüğü üzere, Hukuk Muhakemeleri Kanunu m. 74'üncü maddesi uyarınca, davadan feragat, davaya vekalette özel yetki verilmesini gerektiren hallerden birisidir.

139 Atalı, Ermenek ve Erdoğan (n 1) 574; Atalı, Pekcantez Usul (n 1) 2019; Kuru, Arslan ve Yilmaz, Medeni Usul (n 1) 506; Ansay (n 6) 180; Bilge ve Önen (n 2) 352; Berkin (n 110) 710-711; Üstündağ (n 6) 408; Muşul, (n 7) 437; Kuru, El Kitabı C. 2 (n 6) 1048-1049.

140 Kuru, El Kitabı C. 2 (n 6) 1049; Bilge (n 2) 310; Bilge ve Önen (n 2) 352; Baki Kuru, Medeni Usul Hukuku Ders Kitabı (1. 
için mahkemeden izin alması şart olduğuna göre (TMK m. 462/f. 1, b. 8), davadan feragat edebilmek için de izin alması gerekmektedir ${ }^{141}$.

\section{DAVADAN FERAGATIN GERÇEKLEŞTIRILECEĞi ZAMAN ARALIĞI}

Davadan feragatin ne zamana kadar gerçekleștirilebileceği konusunda 1086 sayılı Hukuk Usulü Muhakemeleri Kanunu’nda herhangi bir düzenleme yer almamaktayd ${ }_{1}{ }^{142}$. Buna karşıllık, 6100 sayılı Hukuk Muhakemeleri Kanunu’nun yürürlüğe girmesi ile birlikte, feragatin yapılabileceği zamansal kesit Kanunda açıkça düzenlenmiştir ${ }^{143}$. 28.07.2020 tarihli ve 7251 sayılı Hukuk Muhakemeleri Kanunu ile Bazı Kanunlarda Değişiklik Yapılması Hakkında Kanun değişikliği sonrasında, davadan feragatin gerçekleștirilme zamanı ve feragat üzerine karar verecek olan merciin neresi olduğu ile verilecek olan karar hakkında düzenlemeler getirilmiştir ${ }^{144}$.

Hukuk Muhakemeleri Kanunu’nun 310'uncu maddesinin 1'inci fikrasında öngörülen düzenleme uyarınca, davadan feragat, hüküm kesinleşinceye kadar yargılamanın her aşamasında yapılabilir ${ }^{145}$ . Davadan feragatin geçerli bir şekilde gerçekleştirilebilmesi için açllmış ve görülmekte olan bir davanın bulunması gerekmektedir ${ }^{146}$. Bu sebeple, yargilamanın ilk derece mahkemesinde devam ettiği bir esnada davadan feragat edilebileceği konusunda herhangi bir tereddüt bulunmamaktadır ${ }^{147}$.

Davanın açılmasından önce ortada derdest bir dava bulunmadığı için davadan feragat edilebilmesi mümkün değildir ${ }^{148}$. Bu sebeple, henüz açılmamış; ancak, ileride açılması mümkün olan bir davadan

Bas1, Legal 2015) 408.

141 Bilge ve Önen (n 2) 352; Kuru, El Kitabı C. 2 (n 6) 1049; Kuru, Ders Kitabı (n 140) 408; Bilge (n 2) 310.

142 Soner (n 11) 442; Akyol Aslan (n 2) 250. Bununla birlikte, doktrinde, talep sonucu dava dilekçesinde ifade edildiği için davadan feragatin de dava dilekçesinde yapılmasının gerektiğini belirten yazarlar söz konusuydu (Postacıoğlu, Usul Hukuku (n 6) 477).

143 Atalı, Ermenek ve Erdoğan (n 1) 574; Karslı (n 1) 374.

144 Bkz.: 7251 Sayılı Kanun m. 29 ile HMK m. 310’a eklenen f. 2 ve f. 3.

145 Atalı, Ermenek ve Erdoğan (n 1) 574; Kuru, Arslan ve Yilmaz, Medeni Usul (n 1) 506; Karslı (n 1) 374; Muşul, (n 7) 441; Görgün, Börü, Toraman ve Kodakoğlu (n 6) 598; Kuru, İstinaf Sistemi (n 7) 388; Atalı, Pekcanttez Usul (n 1) 2012; Budak ve Karaaslan (n 1) N. 13, s. 322; Baki Kuru ve Burak Aydın, İstinaf Sistemine Göre Yazılmış Medenî Usul Hukuku Ders Kitabı (7251 sayılı Kanun Değişiklikleri İşlenmiş 4. Baskı, Yetkin, 2020) 399.

146 Akyol Aslan (n 2) 250; Postacıoğlu, Usul Hukuku (n 6) 477. Davadan feragat edilebilmesi için, feragat beyanının davanın açılmasından sonra yapılması gerekmektedir (Alangoya, Yildırım ve Deren-Yıldırım, Esaslar (n 1) 423). Davadan feragat davaya son veren bir taraf işlemlerinden birisidir (Alangoya, Yıldırım ve Deren-Ylldırım, Esaslar (n 1) 422; Arslan, Yılmaz, Taşpınar-Ayvaz ve Hanağası, (n 13) 564 vd.; Atalı, Ermenek ve Erdoğan (n 1) 571 vd.; Budak ve Karaaslan (n 1) 319 vd.; Görgün, Börü, Toraman ve Kodakoğlu (n 6) 592; Karslı (n 1) 369-370; Kuru, C. IV (n 8) 3543; Kuru, Arslan ve Yılmaz, Medeni Usul (n 1) 505; Kuru, El Kitabı (n 8) 594; Kuru, İstinaf Sistemi (n 7) 386; Muşul, (n 7) 435 vd.; Atalı, Pekcanitez Usul (n 1) 2008 vd.; Postacıŏglu, Usul Hukuku (n 6) 476; Üstündağ (n 6) 568). Davadan feragatin davaya son veren taraf işlemi olması dolayısıyla, yalnızca derdest bir davanın var olması ihtimalinde medeni yargılama hukukunda öngörülen feragat söz konusu olabilir (Karslı (n 1) 374).

147 Postacıoğlu, Usul Hukuku (n 6) 477; Alangoya, Yildırım ve Deren-Yıldırım, Esaslar (n 1) 423.

148 Atalı, Ermenek ve Erdoğan (n 1) 574; Kuru, Arslan ve Yllmaz, Medeni Usul (n 1) 506. Böyle bir durumda, HMK m. 307-312 uyarınca davadan feragat değil; esas haktan feragat söz konusudur (Kuru, Arslan ve Yllmaz, Medeni Usul (n 1) 506). Feragat dava dilekçesinin karşı tarafa tebliğ edilmeden önce yapılamaz. Diğer taraftan dava açıldıktan yani dava dilekçesinin tebliğinden sonra, diğer taraftan da tarafların teşkil edilmesinden önce davanın davasından feragat ettiğini bildirirse, böyle bir durumda, tarafların teşkili sağlanarak hareket edilmesi gerekir (Üstündağ (n 6) 572). 
feragat edilebilmesi söz konusu olamayacaktır ${ }^{149}$. Aksi takdirde, böyle bir durumda, gerçekleştirilecek olan feragat beyanı, esas haktan feragat edilmesi sonucunu doğurur ${ }^{150}$.

Hukuk Muhakemeleri Kanunu'nun 310'uncu maddesinin l'inci fikrası uyarınca, davadan feragat, yalnızca ilk derece mahkemesindeki yargılamanın sona ermesine kadar değil; aynı zamanda, hükmün şekli anlamda kesinleşmesine kadar söz konusu olabilecektir ${ }^{151}$. Bu doğrultuda, ilk derece mahkemesince verilen hükmün kanun yollarına götürülebilmesi için öngörülen süre içerisinde ve bu sürelerin işlemeye devam ettiği bir esnada davadan feragat edilebilmesi mümkündür ${ }^{152}$. Zira, hüküm verilmekle, henüz kesinleşmemişse, davacının talep sonucu üzerindeki tasarruf yetkisi hâlâ devam etmektedir ${ }^{153}$. Bunun gibi, ilk derece mahkemesinden verilen hükmün kanun yollarına - istinaf, temyiz gibi - götürüldüğü bir aşamada da davadan feragat edilmesi söz konusu olabilir ${ }^{154}$.

28.07.2020 tarihinde yürürlüğe giren 7251 sayılı Kanun ile Hukuk Muhakemeleri Kanunu m. 310 hükmüne eklenen 2. ve 3. fikralarla, hükümden sonra feragat hakkında yeni düzenlemeler getirilmiştir ${ }^{155}$. Buna göre, 7251 sayılı Kanun m. 29 ile değiştirilen Hukuk Muhakemeleri Kanunu m.

149 Kuru, El Kitabı (n 8) 596; Kuru, C. IV (n 8) 3562; Atalı, Ermenek ve Erdoğan (n 1) 574.

150 Kuru, C. IV (n 8) 3562; Atalı, Ermenek ve Erdoğan (n 1) 574; Kuru, El Kitabı (n 8) 596.

151 Budak ve Karaaslan (n 1) N. 13, s. 322. Medeni Muhakeme Hukukunda davadan feragat edilebilmesi için hükmün aynı zamanda şekli anlamda kesinleşmemiş olması gerekmektedir (Postacıoğlu, Usul Hukuku (n 6) 478; Atalı, Pekcanttez Usul (n 1) 2012; Kuru, Arslan ve Yılmaz, Medeni Usul (n 1) 506; Atal1, Ermenek ve Erdoğan (n 1) 574; Budak ve Karaaslan (n 1) N. 13, s. 322; Muşul, (n 7) 437). Hüküm kesinleștikten sonra artık ortada derdest bir dava bulunmamaktadır (Üstündağ (n 6) 571). Bunun doğal bir sonucu olarak davadan feragat edilmesi mümkün olmaz (Postacioğlu, Usul Hukuku (n 6) 478; Üstündağ (n 6) 571; Ansay (n 6) 181; Akyol Aslan (n 2) 250 vd.; Karslı (n 1) 374; Kuru, İstinaf Sistemi (n 7) 388; Görgün, Börü, Toraman ve Kodakoğlu (n 6) 598). Hüküm kesinleştikten sonra, davacı tarafından gerçekleştirilen feragat beyanına rağmen, davacının lehine verdiği hükmü icra takibine koyması ve icra edilmesini talep etmesi MK m. 2 uyarınca dürüstlük kuralına aykırılık teşkil eder (Üstündağ (n 6) 571-572).

152 Atalı, Ermenek ve Erdoğan (n 1) 574-575; Atalı, Pekcanttez Usul (n 1) 2012; Budak ve Karaaslan (n 1) N. 13, s. 322; Kuru, El Kitabı (n 8) 597. Diğer taraftan, ilk derece mahkemesince hüküm verildikten sonra ve fakat hükmün kesinleşmesinden önce davadan feragat edilmesi söz konusu olabilir (Atalı, Ermenek ve Erdoğan (n 1) 574; Postacıoğlu, Usul Hukuku (n 6 ) 478; Kuru, C. IV (n 8) 3564).

153 Üstündağ (n 6) 572.

154 Postacıoğlu, Usul Hukuku (n 6) 478; Akyol Aslan (n 2) 257 vd.; Atal, Ermenek ve Erdoğan (n 1) 574-575. Yarg. 10. HD, 23.3.2017, E. 2016/8209, K. 2017/2432 “...Hükmün kesinleşmesinden önceki herhangi bir aşamada davadan feragat edilebilir. Temyiz edilen ve fakat henüz temyiz Dairesince görüşülmeyen bir karar, usûl hukuku çerçevesinde kesinleşmiş olmadığından, bu aşamada davadan feragat mümkündür. Hâkim, gördüğ̈̈ davada tahkikatı bitirip hüküm kurduktan sonra davadan elini çekmiş olur ve kural olarak dava sonunda verilen karar temyiz edilip bozulmadan ve bu suretle yargılamaya yeniden başlanmadan davanın esası ile ilgili hiçbir karar veremez. Feragat, davayı kesin olarak sonuçlandıran bir hukuki neden olduğundan, hakim karar verdikten sonra dahi belgelendirilen feragat üzerine davanın bu nedenle reddine karar verebilir ise de, Yargitay uygulamalarında (örneğin Hukuk Genel Kurulu’nun 21.10.1981 gün 1981/2-551, 1981/683 ve 02.6.1982 günlü 1982/376-547sayll kararları ile 11.04.1940 gün ve 1939/15-1940/70 sayll tevhidi içtihat kararmın gerekçesinden esinlenen uygulama) hüküm temyiz edildikten sonra vaki feragat üzerine mahkemece kendiliğinden bir karar verilmeyerek Yargitay'in bu konuda (feragat konusunda) mahkemece bir karar verilmek üzere hükmün bozulmasına dair verilecek kararından sonra ancak dosyayı ele alabilir ve feragate dayanarak davay reddedebilir. Bu itibarla; somut olayda davadan feragat edildiği bildirdiğinden, hükümden sonra ortaya çıkan ve temyiz incelenmesine usulen engel oluşturan bu hukuki olgu çerçevesinde, davacının 6552 sayıl Yasadan yararlanmak amacıyla davadan feragat ettiği gözetilerek yeniden inceleme yapilmak üzere mahkeme hükmünün bozulmasina karar verilmesi gerekmektedir...” (Lexpera).

1557251 sayılı Kanun ile HMK m. 310 hükmüne eklenen 2. ve 3. fikralar hakkında açıklamalar için bkz.: Arslan, Yllmaz, Taşpınar-Ayvaz ve Hanağası, (n 13) 566; Tanrıver, Medenî Usûl C. I (n 16) 1047; Karslı (n 1) 374; Budak ve Karaaslan (n 1) N. 13, s. 322; Görgün, Börü, Toraman ve Kodakoğlu (n 6) 598; Atalı, Ermenek ve Erdoğan (n 1) 575. 
310/f. 2 uyarınca, davadan feragat hükmün verilmesinden sonra gerçekleştirilmişse, yargılamanın taraflarınca kanun yoluna başvurulmuş olsa bile, dosyanın kanun yolu incelemesine gönderilmesi mümkün olmaz ${ }^{156}$.

Hukuk Muhakemeleri Kanunu'nun 310'uncu madde hükmüne eklenen 3'üncü fikra ile dosyanın temyiz incelemesine gönderilmesinden sonra feragat beyanında bulunulması hakkında düzenlemeler de getirilmiştir. 7251 sayılı Kanun değişikliği (m. 29) ile kabul edilen Hukuk Muhakemeleri Kanunu m. 310/f. 3 uyarınca, davadan feragat, dosyanın temyiz incelemesine gönderilmesinden sonra gerçekleştirilmişse, Yargıtay tarafından temyiz incelemesi yapılmaksızın dosyanın, feragat hususunda "ek karar" verilmek üzere hükmü veren mahkemeye gönderilmesi gerekmektedir ${ }^{157}$.

Görüldügü üzere, 28.07.2020 tarihli ve 7251 sayılı Kanun değişikliğiyle birlikte hükmün verilmesinden sonra davadan feragat edilebileceği HMK'da açıkça düzenlenmiştir. Bununla birlikte, hükümden sonra davadan feragatin mümkün olmadığı istisnai haller de mevcuttur ${ }^{158}$.

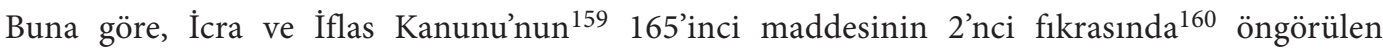
düzenleme uyarınca, asliye ticaret mahkemeleri tarafından görülmekte olan iflas davaları hakkında mahkemece iflas kararı verildikten sonra davadan feragat edilmesi söz konusu olamaz ${ }^{161}$. Zira, ilk derece mahkemesinin kararı ile artık iflasın açılması söz konusu olduğu için, bu noktadan itibaren davacı alacaklının davadan feragat etmesi mümkün değildir ${ }^{162}$. Böyle bir durumda, taraflarca müracaat edilebilecek tek yol, İcra ve İflas Kanunu'nun 182'nci maddesinde öngörülen “iflasın kaldırılması" olacaktır ${ }^{163}$. Bunun gibi istisnai haller bir tarafa, kural olarak, dava açıldıktan sonra gerek ilk derece mahkemesindeki yargılamanın devam ettiği esnada gerekse de kanun yollarına müracaat edildiği ve kanun yollarında incelemenin gerçekleştirildiği bir aşamada, davadan feragat edilebilmesi söz konusu olabilir ${ }^{164}$ (HMK m. 310). Buna karşılık, hüküm kesinleştikten sonra, artık herhangi bir fonksiyonu ve faydası kalmayacağı için - davadan feragat yoluna gidilebilmesi mümkün olmaz ${ }^{165}$.

156 Arslan, Yılmaz, Taşpınar-Ayvaz ve Hanağası, (n 13) 566; Tanrıver, Medenî Usûl C. I (n 16) 1047; Budak ve Karaaslan (n 1) N. 13, s. 322; Karslı (n 1) 374; Atalı, Ermenek ve Erdoğan (n 1) 575; Görgün, Börü, Toraman ve Kodakoğlu (n 6) 598.

157 Tanrıver, Medenî Usûl C. I (n 16) 1047; Arslan, Yılmaz, Taşpınar-Ayvaz ve Hanağası, (n 13) 566; Karslı (n 1) 374; Budak ve Karaaslan (n 1) N. 13, s. 322; Görgün, Börü, Toraman ve Kodakoğlu (n 6) 598; Atalı, Ermenek ve Erdoğan (n 1$) 575$.

158 Kuru, C. IV (n 8) 3568.

159 RG. 19.06.1932, S. 2128

1602004 sayılı İcra ve İflas Kanunu m. 165/f. 2'de bu husus şu şekilde ifade edilmektedir: "İflasa karar verilmesinden sonra iflas davasından feragat geçersizdir."

161 Atalı, Ermenek ve Erdoğan (n 1) 575; Kuru, C. IV (n 8) 3568; Kuru ve Aydın (n 145) 399.

162 Kuru, C. IV (n 8) 3568; Atalı, Ermenek ve Erdoğan (n 1) 575. İflas yargılamasını gerçekleştiren asliye ticaret mahkemesi ilk derece mahkemesi olarak kararını verdikten sonra artık iflas açılmış olacağı için bu karardan feragat edilmesi mümkün olmayacaktır (Atalı, Ermenek ve Erdoğan (n 1) 575).

163 Atalı, Ermenek ve Erdoğan (n 1) 575.

164 Alangoya, Yıldırım ve Deren-Yıldırım, Esaslar (n 1) 423-424.

165 Akyol Aslan (n 2) 250 vd.; Ansay (n 6) 181; Postacıŏlu, Usul Hukuku (n 6) 478; Üstündağ (n 6) 571; Karslı (n 1) 374; Atalı, Ermenek ve Erdoğan (n 1) 574; Görgün, Börü, Toraman ve Kodakoğlu (n 6) 598. 


\section{DAVADAN FERAGAT ÜZERINE KARAR VERECEK OLAN MERCIi VE VERILECEK OLAN KARAR ÜZERINE DEĞERLENDIRMELER}

Mahkeme huzurunda davadan feragat edilmesiyle birlikte, görülmekte olan dava kendiliğinden sona erer ${ }^{166}$. Davadan feragat beyanının ileri sürüldügü mahkeme yalnızca, feragatin Hukuk Muhakemeleri Kanunu'nda öngörülen şekilde (HMK m. 309) yapılıp yapılmadı̆̆ı ile davacının beyanının gerçekten feragat olup olmadığı hususunu araştırması gerekirr ${ }^{167}$. Mahkeme tarafından Kanunda öngörülen şekle uygun olarak ${ }^{168}$ davadan feragat edildiği tespit edilirse, davanın feragat sebebiyle reddine karar verilir ${ }^{169}$.

Kanunda öngörülen şartlara uygun olarak yapılan bir feragat beyanı, kesin hüküm gibi hukuki sonuç doğurur $^{170}$ (HMK m. 311/c. 1). Ayrıca, davadan feragat işlemi usul hukuku hükümlerine göre değil; maddi hukuk hükümlerine göre ortadan kaldırılabilir ${ }^{171}$. Böylelikle, irade bozukluğu hallerinde (hata, hile ve ikrah) (TBK m. 30 vd.) davadan feragatin iptali istenebilir ${ }^{172}$ (HMK m. 311/c. 2).

Davadan feragat iradesi, yargılama hangi aşamada bulunuyorsa onu inceleyecek olan mahkemeye iletilir ${ }^{173}$. İlk derece mahkemesince yargılama devam ederken davadan feragat edilirse, buna ilişkin dilekçenin ilk derece mahkemesine verilmesi gerekir ${ }^{174}$. İstinaf aşamasında davadan feragat etmek

166 Tanriver, Medenî Usûl C. I (n 16) 1052.

167 Kuru, Arslan ve Yılmaz, Medeni Usul (n 1) 506. Feragat beyanının ulaştı̆̆ı mahkeme, yalnızca davacının feragat iradesinin usul hukuku kurallarına uygun bir şekilde gerçekleştirilip gerçekleştirilmediğini değerlendirecektir (Atalı, Pekcanıtez Usul (n 1) 2016).

168 Davadan feragatin şekli konusundaki açıklamalarımız için bkz.: yuk.I,C.

169 Arslan, Yılmaz, Taşpınar-Ayvaz ve Hanağası, (n 13) 567; Kuru, Arslan ve Yılmaz, Medeni Usul (n 1) 506.

170 Pekcanıtez, Atalay ve Özekes, (n 34) 439; Atalı, Pekcanttez Usul (n 1) 2021; Atall, Ermenek ve Erdoğan (n 1) 575; Budak ve Karaaslan (n 1) N. 16, s. 323; Kuru, Arslan ve Yllmaz, Medeni Usul (n 1) 507; Kuru, İstinaf Sistemi (n 7) 389; Görgün, Börü, Toraman ve Kodakoğlu (n 6) 598; Muşul, (n 7) 436; İlhan E. Postacioğlu ve Sümer Altay, Medeni Usul Hukuku Dersleri (Güncelleştirilmiş, Genişletilmiş 8. Bs, Vedat 2020) N. 1458, s. 801; Ansay (n 6) 181; Berkin (n 110) 711-712714; Önen, 'Feragat' (n 5) 33; Soner (n 11) 440; Postacioğlu, Usul Hukuku (n 6) 480-481; Alangoya, Ylldırım ve DerenYıldırım, Esaslar (n 1) 425-426; Kuru, C. IV (n 8) 3632; Kuru, El Kitabı (n 8) 600; İnal (n 81) 978; Karahacıoğlu ve Parlar (n 6) 1342; Bilge ve Önen (n 2) 352; Bilge (n 2) 310.

171 Bilge (n 2) 311; Bilge ve Önen (n 2) 352.

172 Aslan (n 134) 172 vd.; Ansay (n 6) 181; Belgesay (n 110) 193; Berkin (n 110) 714; Bilge ve Önen (n 2) 352-353; Önen, 'Feragat' (n 5) 32; İsmail Hakkı Karafakih, Hukuk Muhakemeleri Usulü Esasları (Ankara Üniversitesi Siyasal Bilgiler Fakültesi Yayınları, Ankara 1952) 235; Kuru, C. IV (n 8) 3647; Üstündağ (n 6) 576; Postacıoğlu, Usul Hukuku (n 6) 482; Alangoya, Yildırım ve Deren-Yildırım, Esaslar (n 1) 426; Atalı, Pekcanitez Usul (n 1) 2023; Karslı (n 1) 375; Atalı, Ermenek ve Erdoğan (n 1) 578; Budak ve Karaaslan (n 1) N. 17, s. 324; Kuru, Arslan ve Yllmaz, Medeni Usul (n 1) 508; Muşul, (n 7) 439; Görgün, Börü, Toraman ve Kodakoğlu (n 6) 599; Kuru, İstinaf Sistemi (n 7) 415; Kuru, El Kitabı (n 8) 603; Bilge (n 2) 311; Mustafa Çenberci, 'Hukuk Davalarında Kesin Hüküm' (1964) 9-12, Adalet Dergisi 1153. Doktrinde, "İrade bozukluğu hallerinde, feragat ve kabulün iptali istenebilir" şeklindeki düzenlemenin madde metninden çıkartılabileceği ifade edilmektedir. Zira, doktrinde ileri sürülen bu görüşe göre, bahsi geçen düzenleme, maddenin ilk cümlesinde öngörülen "Feragat ve kabul, kesin hüküm gibi hukuki sonuç doğurur" şeklindeki ifade ile çelişki halindedir (Yavuz Alangoya, M. Kâmil Yıldırım ve Nevhis Deren-Yıldırım, Hukuk Muhakemeleri Kanunu Tasarısı Değerlendirme ve Önerileri (İstanbul Barosu Yayınları 2006) 169).

173 Kuru, El Kitabı (n 8) 596; Kuru, C. IV (n 8) 3562; Üstündağ (n 6) 572.

174 Kuru, C. IV (n 8) 3586; Üstündağ (n 6) 572. 
istenirse, feragat beyanının bölge adliye mahkemesine sunulması gerekecektir ${ }^{175}$. Mahkemenin verdiği karar hakkında, temyiz kanun yoluna gidilmesi söz konusu ise, feragat iradesi Yargıtay’a yöneltilir ${ }^{176}$.

Davadan feragat edilmesiyle birlikte, yargılamanın nihayete erdirilebilmesi için mahkemece bir karar verilmesine gerek olup olmadığı hususu önem arz etmektedir ${ }^{177}$. Bu kapsamda, doktrinde ileri sürülen bir görüşe göre, davadan feragat gerçekleştirildiği anda sonuçlarını doğurur ${ }^{178}$. Böylelikle, davanın feragat üzerine verilen bir kararla değil de davacının feragat beyanı ile sona ereceği ifade edilmektedir ${ }^{179}$. Davadan feragat edilmesi üzerine, mahkemece davanın feragat sebebiyle sona erdiğini tespit ve tevsik eden bir tutanağın düzenlenmesi yeterli olur ${ }^{180}$. Buna karşılık, doktrinde ileri sürülen diğer bir görüşe göre ise, davadan feragat iradesinin ileri sürülmesinin davanın sona ermesi için yeterli olmadığı; bunun için, ayrıca davadan feragat konusunda bir kararın verilmesinin gerekli olduğu kabul edilmektedir ${ }^{181}$. Kanaatimizce, davadan feragat üzerine, dava kendiliğinden sona erer ${ }^{182}$. Bununla birlikte, mahkemece, davanın feragat sebebiyle sona erdiğini tespit eden bir kararın verilmesi uygun olur ${ }^{183}$.

Dava dosyası ilk derece mahkemesinde ise ve henüz karara bağlanmamışsa, böyle bir durumda davadan feragat edilmesi üzerine, davanın feragat sebebiyle sona erdiğini tespit eden kararı

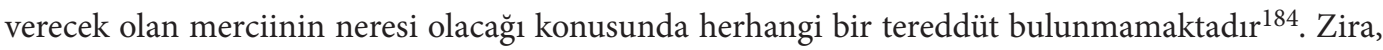
yargılamayı yürüten ilk derece mahkemesince, davanın feragat sebebiyle sona erdiğine dair bir karar veriliir ${ }^{185}$.

Buna karşılık, 28.07.2020 tarihli ve 7251 sayılı Kanunla gerçekleştirilen HMK değişikliğinden önce, ilk derece mahkemesince karar verildikten sonra davacı tarafindan davadan feragat edilirse, bu hususta karar verecek olan merciinin neresi olduğu sorusu ile karşılaşılmaktayd ${ }^{186}$. Zira, kural olarak, ilk derece mahkemesince dava dosyası hakkında karar verildikten sonra, yüksek mahkemece bozma kararı alınmadıkça hükmü veren mahkemenin yeniden inceleme yaparak tekrardan karar verebilme imkânı bulunmamaktayd ${ }^{187}$. Dolayısıyla, ilk derece mahkemesince kararın verilmesinden sonra,

175 Akyol Aslan (n 2) 264 vd.; Karslı (n 1) 374.

$176 \operatorname{Karsli}_{\text {(n } 1)} 374$.

177 Bilge ve Önen (n 2) 352; Atalı, Pekcanitez Usul (n 1) 2015. Davadan feragat edilmesi durumunda, geçerli bir feragat beyanının sonuçlarını doğurabilmesi için ne karşı tarafın muvafakatine ne de hâkimin iznine ihtiyaç bulunmaktadır (HMK m. 309/f. 2) (Kuru, Arslan ve Yılmaz, Medeni Usul (n 1) 505; Kuru, İstinaf Sistemi (n 7) 389; Alangoya, Yıldırım ve Deren-Yıldırım, Esaslar (n 1) 423-424; Görgün, Börü, Toraman ve Kodakoğlu (n 6) 596; Karslı (n 1) 373; Muşul, (n 7) 441).

178 Bilge ve Önen (n 2) 352; Soner (n 11) 444.

179 Bilge ve Önen (n 2) 352; Bilge (n 2) 310-311; Soner (n 11) 444.

180Atal, Pekcantez Usul (n 1) 2015; Tanriver, Medenî Usûl C. I (n 16) 1052.

181 Alangoya, Yıldırım ve Deren-Yıldırım, Esaslar (n 1) 424; Kuru, Arslan ve Yılmaz, Medeni Usul (n 1) 507.

182 Bilge ve Önen (n 2) 352; Bilge (n 2) 310-311; Soner (n 11) 444.

183 Atalı, Pekcanitez Usul (n 1) 2015; Tanrıver, Medenî Usûl C. I (n 16) 1052.

184 Soner (n 11) 444.

185 Üstündağ (n 6) 572; Soner (n 11) 444.

186 Soner (n 11) 444; Koç ve Konuralp (n 23) 66.

187 Budak ve Karaaslan (n 1) N. 13, s. 322. Yarg. 8. HD, 28.02.2017, E. 2016/10528, K. 2017/2702 “Karar kesinleşinceye kadar davadan feragatin mümkün olduğuna, Mahkemece, bir karar verilip, davadan el çektikten sonra temyiz aşamasında 
davadan feragat edilmesi üzerine bu konudaki kararın "ilk derece mahkemesince" mi, yoksa "yüksek mahkemece" mi verileceği hususu tartışmalara sebep olmaktaydı ${ }^{188}$.

Bütün bu açıklamalarımız üzerine belirtmek gerekir ki, çalışmamızın devamında, ilk derece mahkemesince hükmün verilmesinden sonra ve fakat kanun yollarına müracaat süresi içerisindeyken ya da hükmün kanun yollarına götürülmesinden sonraki bir aşamada davadan feragat edilmesi üzerine, davanın feragat sebebiyle sona erdiğini tespit eden kararı verecek olan merciinin neresi olduğu hakkında ayrıntılı açıklamalar yapılacaktır. Bu doğrultuda, aşağıda öncelikle, 28.07.2020 tarihli ve 7251 sayılı HMK değişikliğinden önceki yönetmelik düzenlemeleri ile Yargitay’nn konuya ilişkin uygulaması ifade edilecektir. Sonrasında ise, 7251 sayılı Hukuk Muhakemeleri Kanunu değişikliği ile getirilen yeni düzenlemeler ortaya konularak geçmişten günümüze kadar gelen tartışmaların sona erip ermediği ve HMK m. 310/f. 2, 3’te öngörülen yeni hükümlerin yerindeliği tartışma konusu yapılacaktır.

\section{A. KANUN YOLLARINA MÜRACAAT SÜRESI IÇERISINDEYKEN VEYA DOSYANIN KANUN YOLLARINA GÖTÜRÜLMESINDEN SONRA DAVADAN FERAGAT VE DAVANIN FERAGAT SEBEBIYYE SONA ERDIǦINI TESPIT EDEN KARARI VERECEK OLAN MERCIi}

\section{725I SAYILI KANUN DEĞişiKLIĞiNDEN ÖNCEKI DURUM: YÖNETMELIKTE YER ALAN DÜZENLEMELER VE YARGITAY'IN YAKLAŞIMI}

\section{A. GENEL OLARAK}

İlk derece mahkemesince tarafların aralarındaki uyuşmazlık hakkında hüküm verildikten sonra kanun yollarına müracaat süresinin devam ettiği bir esnada veya dosyanın davanın taraflarınca kanun yollarına götürüldügü bir aşamada davacı tarafından davadan feragat edilmesi ${ }^{189}$ üzerine hangi mercice ne șekilde bir karar verileceği konusunda gerek 1086 sayılı Hukuk Usulü Muhakemeleri Kanunu’nda (m. 91-95) gerekse 6100 sayılı Hukuk Muhakemeleri Kanunu’nda (m. 307-312) herhangi bir düzenleme bulunmamaktayd ${ }^{190}$. Kanun koyucu tarafından mevzuatımızdaki kanunlarda herhangi bir düzenlemenin getirilmemiş olmasına karşılık, Yargıtay’n istikrar kazanan kararları

davacı asil tarafindan davadan feragat edildiğine ve bu aşamada feragat hakkında karar verme yetkisi yerel mahkemeye ait bulunduğuna göre, davacının davadan feragat beyanı hakkında bir karar verilmek üzere bozulması gerekmektedir" (e-uyar).

188 Soner (n 11) 444.

189 Belirtmek isterizki, burada bahsi geçen feragat ile kanun yollarına (istinaf veya temyiz) müracaat konusundaki bir talepten vazgeçilmesi kastedilmemektedir (Baki Kuru, Hukuk Muhakemeleri Usulü, C. V (6. Bası, Demir-Demir 2001) 4494). Kanun yoluna başvurma hakkından feragat ile çalışmamızda ele aldığımız ilk derece mahkemesi tarafından hükmün verilmesinden sonra kanun yoluna müracaat süresi içerisindeyken ya da dosyanın kanun yollarına götürülmesinden sonra dava konusu olan haktan feragat edilmesi birbirlerinden farklıdır. Zira, kanun yoluna başvurmadan feragat hakkında ayrıntılı bilgi için bkz.: Kuru, C. V (n 189) 4490-4494.

190 Bkz.: HMK m. 307-312. 
ile uygulamada mahkemelerce izlenen bir prosedür söz konusuydu ${ }^{191}$. Bununla birlikte, 6100 sayılı Hukuk Muhakemeleri Kanunu’nun 01.10.2011 tarihinde yürürlüğe girmesinden sonra kabul edilen yönetmelikler ile ilk derece mahkemesince hükmün verilmesinden sonra davadan feragat edilmesi durumunda, incelemeyi gerçekleştirecek olan merci ile vereceği karar konusunda mevzuatımızda düzenleme yapılması yoluna gidilmiştir ${ }^{192}$. Bu konuda getirilen ilk düzenleme, Hukuk Muhakemeleri Kanunu Yönetmeliğinin 193 ("HMK Yönetmeliği”) hükümleri arasında yer almaktadır ${ }^{194}$. Hukuk Muhakemeleri Kanunu Yönetmeliği'nin yürürlükten kaldırılmasından sonra, Bölge Adliye ve

191 Yargitay’n hüküm verildikten sonra henüz kanun yolu süresi başlamadan ya da kanun yolu süresi içerisindeyken davadan feragat halinde feragat nedeniyle karar vererek davaya son verildiğini ortaya koyma yetkisinin, Yargitay'da olduğu yönünde kararları ve mevcut bir uygulamamız söz konusuydu (Kuru, C. IV (n 8) 3565-3567). Yargıtay’ın hüküm verildikten fakat kanun yolları mahkemesine ulaşmasından önce inceleme merciinin Yargitay olması gerektiği kanunundaki kararları șu șekildedir: “...Mahkemece isteğe uygun olarak boșanmaya hükmedilmiş ve karar davacıya 16.1.1986'da tebliği olunmuștur. Davacı henüz hüküm kesinleșmeden verdiği 20.01.1986 tarihli dilekçesi ile davadan feragat ettiğini bildirmiştir. Dilekçe alıırken mahkemece davacın hüviyeti de tesbit edildiğinden feragat dilekçesinin davacıya ait olduğunda kuşku yoktur. O halde feragat sebebi ile davanın reddine karar verilmesi zorunluğu doğmuştur. Ancak mahkemece, işten el çekildiği gerekçesi ile bu dilekçe üzerine işlem yapılmadığı anlaşılmaktadır. Görülmektedir ki feragat dilekçesi üzerine Hakimlikçe işlem ifası için mahkemenin dosyay yeniden ele almasının ve içine girebilmesin sağlamak gerekmektedir. Öyle ise davadan feragat dilekçesini aynı zamanda temyiz dilekçesi gibi yorumlamak, hâkime işlem yapabilmesi için kararın bozularak dosyanın mahkemesine gönderilmesine karar vermek zorunluluğu vardır. Davacı karar kesinleşmeden davadan feragat ettiğinden feragat sebebi ile dava red edilmek üzere hükmün bozulması gerekmiştir..." (Yarg. 2. HD, 30.01.1992, 556/784; Kuru, C. IV (n 8) 3566-3567). Uygulamada, hükmün temyiz kanun yoluna müracaat edildikten sonra ve fakat dosyanın yüksek mahkememiz Yargıtay’a intikal etmediği bir aşamada davadan feragat edilmesi durumunda bu konuda ilgili merciinin Yargitay olacağı ve Yargitay’n feragat sebebiyle hükmü bozması üzerine yerel mahkemece davanın feragat sebebiyle reddedileceği ifade edilmekteydi. Yargıtay’ın bu yöndeki bir kararı şu şekildedir: "Davacı, kocası davalı Ali aleyhine şiddetli geçimsizlik sebebiyle boşanma davası açmış, mahkemece dava kabul edilerek boşanmaya karar verilmiştir. Bu karar, davacın temyizi üzerine Özel Dairece bozulmuş, yerel mahkeme önceki kararında direnmiştir. Davacı, direnme kararın temyiz etmiş ve temyiz dilekçesinde (davasından feragat) ettiğini bildirmiştir. Davacı davasından feragat ettiğine göre, henüz kesinleşmemiş bulunan boşanma hükmünün ilk şartı olan (dava) ortadan kalkmış bulunmaktadır. Bu durum karşısında, yerel mahkemece davadan feragat hakkında bir karar verilebilmesi için direnme kararının bozulması gerekir. Nitekim, Yargıtay’n yerleşik uygulaması da bu yoldadır (11.4.1980 gün ve 70 sayılı İçtihadı Birleştirme Kararının gerekçesi; HGK 16.11.1966 gün ve 1438-290 s. K.; HGK. 21101981 gün ve 2645-4019 s.k.). O halde, yukarıda yapılan açıklamalara göre; davacı davasından feragat ettiğini bildirdiğinden bu hususta mahkemesince bir karar verilmek üzere, boşanmaya ilişkin direnme kararı bozulmalıdır..." (Yarg. HGK 5.2.1982, 2/1310-86, Kuru, C. IV (n 8) 3569-3570). Hükmedilen kararı ilişkin dosyanın kanun yolu (temyiz) incelemesindeyken davacı tarafından davadan feragat edilmesi durumunda, bu durumda dosya zaten kanun yolu mahkemesi olan Yargitay'da olup Yargitay, feragat incelemesini gerçekleştirmektedir. Yargıtay'in bu yöndeki yerleşik uygulamasını ortaya koyan kararı şu şekildedir: Yarg. 4. HD, 19.12.1985, 9159/10179 “... Davadan feragat kesin bir hükmün sonuçlarını doğurur. Davacı taraf temyiz aşamasında davadan feragat ettiğinden bu feragat karşı tarafın kabulüne bağh bulunmadığından hükmün bozulmasına ve mevcut feragat gereğince işlem yapılmak üzere dosyanın mahalline gönderilmesine karar verilmek gerekmiştir. Sonuç: Temyiz olunan hükmün yukarıdaki nedenlerle mahalli mahkemece davanın reddine karar verilmek üzere bozulmasına karar verildi...” (Kuru, C. IV (n 8) 3572). Yarg. 21. HD, 13.12.2008, E. 2007/2209, K. 2008/23658 “...Davaci 22.05.2007 tarihli dilekçesi ile kararın temyizinden sonra davadan feragat ettiğini belirtmiş ise de Yargıtay Hukuk Genel Kurulu’nun 11.02.2004 gün, E: 2004/21-54, K: 2004/54 sayll kararında vurgulandı̆̆ üzere 506 sayll yasanın 6.maddesi uyarınca sosyal güvenlik hakkından vazgeçilemeyeceği açıkça ortada olduğundan hizmet tesbitine ilişkin temyiz yönünden temyiz itirazlarının incelenmesi gerekmiştir... Davacı 22.05.2007 tarihli dilekçesi ile kararın temyizinden sonra davadan feragat ettiğini bildirdiğinden iş̧̧ilik alacakları yönünden, 11.04 .1940 günlü ve 70 sayll İçtihadı Birleştirme kararı gereğince, hükümden sonra ortaya çıkan ve esas hükmün temyiz yoluyla incelenmesine engel olan bu durum karşısında mahkemenin feragat hakkında bir karar vermesi için hükmün bozulması gerekmiştir..." (Lexpera).

192 Yönetmeliklerde yer alan düzenlemelere ilişkin açıklamalar için bkz.: Budak ve Karaaslan (n 1) N. 13, s. 322; Atalı, Ermenek ve Erdoğan (n 1) 575; Atalı, Pekcanitez Usul (n 1) 2013.

193 RG. 3.4.2012, S. 28253.

194 https://www.barobirlik.org.tr/Haberler/hukuk-muhakemeleri-kanunu-yonetmeligi-12642. (Erişim Tarihi: 06.04.2020). 
Adli Yargı İlk Derece Mahkemeleri ile Cumhuriyet Başsavcılıkları İdari ve Yazı İşleri Hizmetlerinin Yürütülmesine Dair Yönetmelik195 (“Yazı İşleri Yönetmelĭğ’) yürürlüğe girmiştir196. Yürürlüğe giren yeni yönetmelik hükümleri arasında da konuya ilişkin bir düzenleme getirilmiştir ${ }^{197}$. Bu sebeple, aşağıda, yürürlükten kaldırılan Hukuk Muhakemeleri Kanunu Yönetmeliği’nde ve onun yerine kabul edilen Bölge Adliye ve Adli Yargı İlk Derece Mahkemeleri ile Cumhuriyet Başsavcılıkları İdari ve Yazı İşleri Hizmetlerinin Yürütülmesine Dair Yönetmelik’te getirilen düzenlemelerin açıklanması yoluna gidilecektir.

\section{B. MEVZUATIMIZDA YER ALAN YÖNETMELIK HÜKÜMLERi ILE GETIRILEN DÜZENLEMELER}

\section{aa. Hukuk Muhakemeleri Kanunu Yönetmeliği ile Getirilen Düzenleme (m. 57)}

İlk derece mahkemesinden karar verildikten sonra ve fakat hükmün kesinleşmesinden önce davadan feragat edilmesi hakkında ilk olarak 3 Nisan 2012 tarihinde 28253 sayılı Resmî Gazetede yayımlanan Hukuk Muhakemeleri Kanunu Yönetmeliği’nin 57’nci maddesinde bir düzenleme getirilmiştir ${ }^{198}$. Hukuk Muhakemeleri Kanunu Yönetmeliği’nin "karar verilmiş dosyalara ilişkin hükümler" kenar başl1kl 57 'nci maddesinde, "Hükmün kesinleşmesinden önce davadan feragat, davay kabul veya sulh halinde, hâkim dosya üzerinden bu konuda ek karar verir. Taraflarca kanun yoluna başvurulmuş olsa dahi sirf bu nedenlerle dosya istinaf veya temyiz incelemesine gönderilmez." denilmektedir ${ }^{199}$.

Görüldüğg̈ üzere, Hukuk Muhakemeleri Kanunu Yönetmeliği’nin 57’nci maddesi uyarınca, hükmün kesinleşmesinden önce davadan feragat edilmesi halinde, mahkemenin hâkimi tarafindan buna ilişkin olarak "ek karar" verilebileceği şeklinde yeni bir düzenleme getirilmişti ${ }^{200}$. Bununla birlikte, m. 57’deki düzenlemeyi içeren Hukuk Muhakemeleri Kanunu Yönetmeliği'nin kısa bir süre sonra yürürlükten kaldırılması sebebiyle, bahsi geçen hükmün uygulanmasına son verilmiștir ${ }^{201}$.

\section{bb. Bölge Adliye ve Adli Yargı İlk Derece Mahkemeleri ile Cumhuriyet Başsavcılıkları İdari ve Yazı İşleri Hizmetlerinin Yürütülmesine Dair Yönetmelik ile Getirilen Düzenleme (m. 215)}

Yürürlükten kaldırılan Hukuk Muhakemeleri Kanunu Yönetmeliğìnin yerini Bölge Adliye ve Adli Yargı İlk Derece Mahkemeleri ile Cumhuriyet Başsavcılıkları İdari ve Yazı İşleri Hizmetlerinin

195 RG. 06.09.2015, S. 29437.

196 http://www.adalet.gov.tr/duyurular/2015/agustos/yonetmelik.html (Erişim Tarihi: 29.05.2020).

197 Yürürlükten kaldırılan Hukuk Muhakemeleri Kanunu Yönetmeliği m. 57’nin yerini alan Hukuk Muhakemeleri Kanunu Yönetmeliğinin yürürlükten kaldırılmasından sonra Bölge Adliye ve Adli Yargı İlk Derece Mahkemeleri ile Cumhuriyet Başsavcılıkları İdari ve Yazı İşleri Hizmetlerinin Yürütülmesine Dair Yönetmelik m. 215 düzenlemesinde, ilk derece mahkemesince hükmün verilmesinden ve fakat şekli anlamda kesin hüküm teşkil etmesinden önce davadan feragat edilmesi halinde, hakimin dosya üzerinden bu hususa ilişkin olarak ek karar verebilmesine imkan tanınarak dosyanın istinaf ve temyiz mahkemelerine gönderilmemesi olanaklı kılınmıştır (Atalı, Pekcanıtez Usul (n 1) 2013).

198 Ali Cem Budak ve Vural Karaaslan, Medeni Usul Hukuku (3. Bası, Adalet 2019) N. 13, s. 306.

199 Budak ve Karaaslan 3 Bs (n 198) N. 13, s. 306

200 ibid 306.

201 Atalı, Pekcantez Usul (n 1) 2013. 
Yürütülmesine Dair Yönetmelik almıştır ${ }^{202}$. 5 Ağustos 2015 tarihli 29437 sayılı Resmî Gazete’de yayınlanan Bölge Adliye ve Adli Yargı İlk Derece Mahkemeleri ile Cumhuriyet Başsavcılıkları İdari ve Yazı İşleri Hizmetlerinin Yürütülmesine Dair Yönetmeliğin "karar verilmiş dosyalara ilişkin işlemler" kenar başlıklı 215’inci maddesinde bu hususa ilişkin olarak açık bir düzenleme getirilmiştir. Buna göre, Yönetmeliğin 215’inci maddesinde, “Hükmün kesinleşmesinden önce davadan feragat, davayı kabul veya sulh hâlinde, hâkim dosya üzerinden bu konuda ek karar verir. Taraflarca kanun yoluna başvurulmuş olsa dahi sirf bu nedenlerle dosya istinaf veya temyiz incelemesine gönderilmez." denilmektedir.

Görüldüğü üzere, Yönetmeliğin 215’inci maddesinde öngörülen düzenleme, yürürlükten kaldırılan Hukuk Muhakemeleri Kanunu Yönetmeliğiinin 57’nci maddesi ile birebir aynı hususları içermektedir ${ }^{203}$. İlk derece mahkemesi tarafından hükmün verilmesinden sonra ve fakat, dava dosyasının kanun yolu mahkemesine gönderilmesinden önce, davadan feragat etmek isteyen davacının, bu talebi üzerine hangi mahkeme tarafından ne şekilde bir karar verileceği, Bölge Adliye ve Adli Yargı İlk Derece Mahkemeleri ile Cumhuriyet Başsavcılıkları İdari ve Yazı İşleri Hizmetlerinin Yürütülmesine Dair Yönetmeliğin 215’inci maddesinde (eski HMK Yönetmeliği m. 57’de) açıkça ifade edilmektedir ${ }^{204}$.

Yönetmeliğin 215'inci maddesi uyarınca, ilk derece mahkemesince verilen karar üzerine dosyanın kanun yoluna ulaşmasından önce davacı tarafından davadan feragat edilmek istenirse, ilk derece mahkemesinin hâkimi tarafından dosya üzerinden feragat sebebiyle "ek karar" verilebilir ${ }^{205}$. Böyle bir durumda, davacının feragat beyanı üzerine feragat sebebiyle davanın sona erdiğini tespit eden işlemleri yapacak olan merci "kararı veren mahkeme” olacaktır ${ }^{206}$. Görüldüğü üzere, Yönetmeliğin 215 'inci maddesinde getirilen düzenleme uyarınca, davacı tarafından feragat edilen dosyanın, istinaf

202 http://www.adalet.gov.tr/duyurular/2013/agustos/yonetmelikbasbakanlik.pdf (Erişim Tarihi: 06.04.2020).

203 Karş.: Yazı İşleri Yönetmeliği m. 215; HMK Yönetmeliği m. 57. Yarg. 23. HD, 21.04.2016, E. 2015/8604, K. 2566 “...6100 sayılı HMK'da bu konuda açık bir düzenleme yapılmamış, ancak bu kanuna dayanılarak çıkarılan ve yeni yönetmeliğin yürürlüğe girdiği 06.08.2015 tarihine kadar yürürlükte bulunan Hukuk Muhakemeleri Kanunu Yönetmeliğinin "Karar verilmiş dosyalara ilişkin işlemler" başlıkl 57. maddesinde "Hükmün kesinleşmesinden önce davadan feragat davayı kabul veya sulh halinde, hâkim dosya üzerinden bu konuda ek karar verir. Taraflarca kanun yoluna başvurulmuş olsa dahi sırf bu nedenlerle dosya istinaf veya temyiz incelemesine gönderilmez." düzenlemesi getirilmiştir. 06.08.2015 tarihinde yürürlüğe giren Bölge Adliye ve Adli Yargı İlk Derece Mahkemeleri ile Cumhuriyet Başsavcılıkları İdari ve Yazı İsleri Hizmetlerinin Yürütülmesine Dair Yönetmeliğin 215. maddesi de, aynı düzenlemeyi içermektedir...” (e-uyar).

204 Yarg. 22.HD, 10.05.2018, E. 2017/15145, K. 2018/11650 “...06.08.2015 tarihli ve 29437 sayll Resmî Gazete'de yayımlanarak yürürlüğe giren, Bölge Adliye ve Adli Yargı İlk Derece Mahkemeleri ile Cumhuriyet Başsavcılıkları İdari ve Yazı İşleri Hizmetlerinin Yürütülmesine Dair Yönetmeliğin 215. maddesinde "Hükmün kesinleşmesinden önce davadan feragat, davayı kabul veya sulh halinde, hâkim dosya üzerinden bu konuda ek karar verir. Taraflarca kanun yoluna başvurulmuş olsa dahi sırf bu nedenlerle dosya istinaf veya temyiz incelemesine gönderilmez." düzenlemesi yer almaktadır. Anılan sebeple, davacı vekilin dosyada mevcut vekaletname belgesinde davadan feragate yetkisinin bulunmadiğı anlaşıldığından, öncelikle davadan feragat yetkisini içeren vekaletname temin edilerek hükümden sonra ortaya çıkan ve temyiz incelemesine usulen engel oluşturan davadan feragat beyanının Mahkemece değerlendirilip karara bağlanması için dosyanın Mahkemesine iadesine karar vermek gerekmiştir..." (Lexpera).

205 Atalı, Ermenek ve Erdoğan (n 1) 575; Atalı, Pekcanıtez Usul (n 1) 2013; Budak ve Karaaslan (n 1) N. 13 , s. 322.

206 Atalı, Ermenek ve Erdoğan (n 1) 575. 
veya temyiz mahkemelerine gönderilmesine imkân tanınmamıştır ${ }^{207}$ (Yazı İşleri Yönetmeliği m. 215/c. 2).

Yazı İşleri Yönetmeliği m. 215/c. 1 uyarınca, hükümden sonra davadan feragat edilmesi üzerine, ek karar vererek davanın feragat sebebiyle sona erdiğini ortaya koyacak olan ilk derece mahkemesinin yeniden duruşma yapmasına gerek yoktur. Zira, bu halde, ilk derece mahkemesi, hükümden sonra feragat sebebiyle kararını “dosya üzerinden” verir"208 (Yazı İşleri Yönetmeliği m. 215/c. 1). Bu durumda, ilk derece mahkemesinin hâkimi, dosya üzerinden vereceği ek kararla davanın reddine hükmedebilir ${ }^{209}$.

Mevzuatımızda ilk olarak, Hukuk Muhakemeleri Kanunu Yönetmeliğinnin 57’nci maddesinde öngörülen, sonrasında ise, Bölge Adliye ve Adli Yargı İlk derece Mahkemeleri ile Cumhuriyet Başsavcılıkları İdari ve Yazı İşleri Hizmetlerinin Yürütülmesine Dair Yönetmeliğin 215’inci maddesinde yer alan imkânın yerindeliği Yargıtay kararlarında ve doktrinde tartışmalıydı. Zira, yukarıda ifade edildiği üzere ${ }^{210}$ - Yargitay tarafından, yüksek mahkemece ek karar verilemeyeceği şeklinde kararlar ortaya konulmaktaydı ${ }^{211}$. Aynı zamanda, doktrinde ileri sürülen bazı görüşlerde, Yazı İşleri Yönetmeliği’nin 215’inci maddesinin (eski HMK Yönetmeliği m. 57) isabetli olmayan yönleri mevcuttu ${ }^{212}$. Doktrinde ileri sürülen bir görüşe göre, hükmün ilk derece mahkemesince verilmesinden sonra davadan feragat edilmesi konusunda getirilen düzenlemenin kanun yerine yönetmelikte yer almasının uygun olmadığı ve “ek karar” kavramının, nispi kesin hüküm kurumuyla bağdaşmadığ belirtilerek, bu konuda düzenleme getiren yönetmelik hükmünün hukuki sonuç doğurmayacağ ileri sürülmekteydi ${ }^{213}$. Yine, doktrinde ileri sürülen diğer bir görüşe göre, dosyadan el çeken hâkim nihai kararını vermiş olacağı için tekrardan dosyayı ele alarak yeni veya ek bir karar veremeyecektir ${ }^{214}$. Aynı zamanda, medenî usûl hukukunda, ilk derece mahkemesince ek karar verilebileceği şeklinde bir düzenlemenin yer almaması sebebiyle Yönetmeliğin 215'inci maddesindeki düzenlemenin sorun teşkil edeceği ifade edilmekteydi ${ }^{215}$. Kanaatimizce de hükmün verilmesinden sonraki bir aşamada davadan feragat edilmesi konusunda kanun yerine yönetmelikte düzenleme getirilmesinin kanun yapma tekniği ile bağdaşmadığı ortadaydı ${ }^{216}$. Buna karşılık, kanun koyucunun, Yönetmeliğin

207 Atalı, Pekcanitez Usul (n 1) 2013.

208 Yönetmeliğin 215'inci maddesinde ilk derece mahkemesince dosya üzerinden karar verileceği açıça ifade edilmektedir. Bkz.: Yazı İşleri Yönetmeliği m. 215/c. 1.

209 Atalı, Ermenek ve Erdoğan (n 1) 575; Atalı, Pekcanitez Usul (n 1) 2013.

210 Bkz.: yuk. II, A, 1, c, bb.

211 Atalı, Pekcanıtez Usul (n 1) 2013. Yarg. 19. HD, 09.02.2017, E. 2016/2118, K. 2017/1004“...Mahkeme işin esasına yönelik karar verdikten sonra davadan el çekmiştir. Feragat sebebiyle bir ek karar oluşturması mümkün değildir. Bu nedenle 01.10.2015 ek kararın kaldırılmasına, tarafların diğer temyiz itirazları yönünden yapılan incelemede her ne kadar mahkeme kararı taraflarca temyiz edilmişse de 01.10.2015 tarihinde davacı davadan feragat etmiş olduğundan feragat sebebiyle bir karar verilmek üzere mahkeme kararının bozulması gerekmiştir...” (Lexpera).

212 Yönetmelik ile getirilen "ek karar” alma imkânı hakkında eleştiriler için bkz.: Budak ve Karaaslan (n 1) N. 13, s. 322; Koç ve Konuralp (n 23) 66.

213 Budak ve Karaaslan (n 1) N. 13, s. 322.

214 Koç ve Konuralp (n 23) 66.

215 ibid 66.

216 Taşpınar Ayvaz (n 30) 552-555; Arslan, Yılmaz, Taşpınar-Ayvaz ve Hanağası, (n 13) 566, dn. 2. 
215’inci maddesinde (eski HMK Yönetmeliği m. 57) getirdiği ve mahkemece ek karar verilebilmesini mümkün kılan düzenlemesi, usul ekonomisi ilkesi bakımından oldukça önemliydi ${ }^{217}$. Bu sebeple, Yönetmeliğin 215’inci maddesinde öngörülen düzenlemeye temel teşkil edecek kanun hükümlerinin gerçekleştirilecek olan değişikliklerle HMK’ya eklenmesi gereklilik arz etmekteydi ${ }^{218}$. Zira, doktrinde ileri sürülen görüşlerde ${ }^{219}$, yargılama hukukuna ilişkin kuralların kanunla düzenlenmesinin gerektiği şeklindeki Anayasal ilkenin (HMK m. 142) varlığında, kanun yerine yönetmelikle bir düzenlemenin getirilmesinin uygun olmadığ $\breve{1}_{1}$ fade edilmekteydi ${ }^{220}$. Bu sebeple, doktrinde, Hukuk Muhakemeleri Kanunu’nda da hüküm getirilmesinin gerektiği ileri sürülerek Kanunda değişiklik yapılması fikri savunulmaktaydi ${ }^{221}$.

\section{YARGITAY'IN YAKLAŞIMI}

\section{aa. Genel Olarak}

Yönetmelik düzenlemelerinin (eski HMK Yönetmeliği m. 57; Yazı İşleri Yönetmeliği m. 215) ve 7251 sayılı HMK değişikliğinin yürürlüğe girmesinden önce, ilk derece mahkemesince hükmün verilmesinden sonra, henüz kanun yollarına müracaat süresi içeresindeyken davacı tarafından davadan feragat edilmesi söz konusu olduğunda, Yargıtay’ın bu konudaki yaklaşımı, uygulamanın ne şekilde olduğunun anlaşılabilmesi bakımından önemli bir kaynak olarak karşımıza çıkmaktaydı ${ }^{222}$. Ayrıca, Yargıtay tarafından, yönetmelik düzenlemelerinin (eski HMK Yönetmeliği m. 57; Yazı İşleri Yönetmeliği m. 215) yürürlüğe girmesinden sonra da geçmişten beri süregelen uygulamanın devam ettirilmesi konusunda ısrar edilmesi söz konusuydu. Bu sebeple, Yargıtay tarafından ortaya konulan kararlar ile şekillenen uygulamanın yerindeliğinin tartışılabilmesi bakımından, Yargıtay’n bu konudaki yaklaşımının açıklanarak ifade edilmesi önem arz etmektedir ${ }^{223}$.

217 Atali, Pekcanitez Usul (n 1) 2013.

218 Taşpınar Ayvaz (n 30) 552-555.

219 ibid 552-555.

220 Arslan, Yılmaz, Taşpınar-Ayvaz ve Hanağası, (n 13) 566, dn. 2; Taşpınar Ayvaz, s. 552-555.

221 Taşpınar Ayvaz (n 30) 552 vd.; Akyol Aslan (n 2) 262.

222 Yönetmelik düzenlemelerinin (eski HMK Yönetmeliği m. 57; Yazı İșleri Yönetmeliği m. 215) ve 7251 sayılı HMK değişikliğinin yürürlüğe girmesinden önce, ilk derece mahkemesince hüküm verildikten sonra kanun yollarına müracaat süresi içerisinde davadan feragat edilmesi durumunda hangi merci tarafından ne şekilde karar verileceği konusunda mevzuatımızda herhangi bir düzenleme bulunmamaktaydı (Akyol Aslan (n 2) 262; Soner (n 11) 444). Bu sebeple, Yargıtay tarafından verilen kararlarla şekillenen uygulama çerçevesinde mevcut boşluk doldurulmaktaydı. Böylelikle, hükmün verilmesinden sonra davadan feragat edilmesi durumunda, gerek 1086 sayılı Hukuk Usulü Muhakemeleri Kanunu zamanında gerekse de 6100 sayılı Hukuk Muhakemeleri Kanunu’nun yürürlükte olduğu dönemde Yargıtay kararlarına yansıyan uygulama yol gösterici olması sebebiyle önem arz etmekteydi. İlk derece mahkemesince hükmün verilmesinden sonra, kanun yoluna müracaat süresi başlamadan önce veya kanun yolu süresi içerisinde davadan feragat edilirse, Yargıtay kararlarına yansıyan uygulama hakkında ayrıntılı bilgi için bkz.: Kuru, C. IV (n 8) 3564 vd.

223 Aynı zamanda, kanun yolları aşamasındaki bir davadan feragat edilmesi konusunda da Yargıtay’ın aynı yönde pek çok kararı mevcuttur. Kanun yolları aşamasında olan dosyanın yüksek mahkemece incelendiği bir esnada davadan feragat edilmesi durumunda Yargıtay kararlarına yansıyan ve geçmişten günümüze kadar süregelen bir uygulama da bulunmaktadır. Yarg. 14. HD, 3.2.2014, E. 2013/14170, K. 2014/1212 “...Hükmü, davalılar vekili temyiz etmiştir. Davacı vekili, dosyanın Yargıtay’a gönderilmesinden sonra vermiş olduğu kimliği onayl 20.01.2014 tarihli dilekçesi ile davasından feragat ettiğini bildirmiştir. Davacı vekilinin dosya içerisinde bulunan vekaletnamesinde davadan feragat etme yetkisi 


\section{bb. 7251 sayılı HMK Değişikliğinden Önceki Dönemde Kanun Yollarına Müracaat Süresi İcerisindeyken Davadan Feragat Konusunda Yargıtay'ın Yaklaşımı}

7251 sayılı HMK değişikliğinden önceki dönemde, Yargıtay’ın yerleşik uygulamasına göre, ilk derece mahkemesince hüküm verildikten sonra ve fakat kanun yolu incelemesinin gerçekleştirilmesinden önce davadan feragat edilmesi durumunda, dosyanın öncelikle Yargitay’a gönderilmesi gerekmekteydi. Zira, kural olarak, ilk derece mahkemesinin hâkimi, dava konusu hakkında karar verdikten sonra dosyadan el çektiği için tekrardan davayı ele alarak esasa etkili bir karar veremeyecekti ${ }^{224}$. Bu sebeple, Yargıtay kararlarına yansıyan uygulama uyarınca, ilk derece mahkemesince verilen karara karşı henüz kanun yoluna gidilmediği bir aşamada, davadan feragat edilmesi durumunda, mahkemeye sunulan feragat dilekçesi, temyiz talebi olarak kabul edilerek ${ }^{225}$ dosyanın Yargitay'a sevk edilmesi sağlanmaktaydı ${ }^{226}$. Böylelikle, ilk derece mahkemesine sunulan davadan feragat dilekçesiyle, dava dosyasının Yargitay’a gönderilmesi söz konusu olmaktaydı227. Bunun üzerine, davadan feragat edildiği gerekçesiyle Yargıtay tarafından ilk derece mahkemesinin verdiği karar bozulmaktaydı ${ }^{228}$.

bulunduğu anlaşılmıştır (...)16.11.1966 tarihli ve 1438/290 sayılı, 27.05.1992 tarihli ve 1992/2-250/364 sayılı Kararları). Mahkemece bir karar verilip davadan el çekildikten sonra temyiz aşamasında davadan feragat edildiğinden ve bu aşamada dahi feragat hakkında bir karar verilmesi gerektiğinden hükmün davacının davadan feragati hakkında mahkemesince bir karar verilmek üzere bozulması gerekmiştir..” (Lexpera). Yarg. 8. HD, E. 2017/14239, K. 2017/16613 “...HMK'nun 310. maddesine göre davadan feragat, hüküm kesinleşinceye kadar her zaman yapılabilir. HMK'nun 311. maddesinde ise feragat kesin hüküm gibi hukuki sonuç doğuracağı ve irade bozukluğu hallerinde feragat ve kabulün iptali istenebileceğ belirtilmiştir. Karar kesinleşinceye kadar davadan feragatin mümkün olduğuna, Mahkemece, bir karar verilip, davadan el çekildikten sonra temyiz aşamasında davacı vekili tarafından feragat edildiğine, bu aşamada feragat hakkında karar verme yetkisi yerel mahkemeye ait bulunduğuna göre, davacı vekilinin feragat beyanı hakkında bir karar verilmek üzere hükmün bozulması gerekmektedir. SONUÇ: Açıklanan nedenle, davacı vekilinin feragat talebi dikkate alınmak suretiyle hüküm kurulmak üzere yerel mahkeme kararının 6100 sayıl HMK’nun Geçici 3. maddesinin yollamasıyla 1086 sayıl HUMK'nun 428. maddesi uyarınca BOZULMASINA...” (Lexpera). Yargıtay'ın benzer yöndeki kararları için bkz.: Yarg. 14. HD, 8.10.2015, E. 2015/6558, K. 2015/8662 (Lexpera).

224 Belgesay (n 110) 192; Soner (n 11) 444; Koç ve Konuralp (n 23$) 66$.

225 Kuru, C. IV (n 8) 3565; Atalı, Pekcantez Usul (n 1) 2013.

226 Yargıtay kararlarına yansıyan, yerleşik uygulama uyarınca, ilk derece mahkemesince hüküm verildikten sonrasında feragat beyanı üzerine dosyanın temyiz mahkemesince inceleneceği yönünde karar verilmekteydi. Yarg. 2. HD, 05.05.1999, 2708/4669 “...Taraflar arasındaki boşanma davasının yapılan muhakemesi sonunda mahkemece isteğe uygun olarak boşanmaya hükmedilmiş, temyiz süresi içinde davacı 7.12.1988 tarihli dilekçesi ile davadan feragat etmiştir. Karar kesinleşinceye kadar davanın her safhasında davadan feragat mümkündür. Feragat kesin hükmün hukuki neticelerini doğurur (HUMK m. 95). Öte yandan işlem doğrultusunda oluşan hükmün kesinleşmesi bu kuralla çelişen bir sonuç doğuracaktır. O halde, henüz kesinleşmemiş hükmün ortadan kaldırılması zorunludur. Mahkemeler Kanunda öngörülen istisnalar dışında kendi hükümlerini kendileri kaldıramazlar. İlk derece mahkemelerinin kararlarını bozup kaldırma yetkisi münhasıran Yargıtaya aittir (Yargitay Kanunu 1; HUMK m. 428). Mahkemece kadının davası kabul edilerek boşanmaya karar verilmekle dosyadan el çekilmiştir. Davacı kadının hüküm kesinleşmeden önce verdiği 7.12.1998 tarihli dilekçesinin temyiz isteği olarak kabulü ile, dosyanın ele alını feragat sebebi ile gerekli kararın verilmesi gerekirken ek kararla davanın feragat sebebi ile gerekli kararın verilmesi gerekirken ek kararla davanın feragat sebebi ile reddine karar verilmesi doğru görülmemiştir...” (YKD 1999/10, s. 1364; Aynı karar için bkz.: Kuru, C. IV (n 8) 3567). Yarg. 1. HD, 12.12.2002, 13589/14189 “...mahkemece, karardan sonraki dönemde usule ilişkin ayrık hallerde dişında, davayı tekrar ele alıp, esasa etkili karar verilemez. Mahkemece işaret edilen doğrultuda inceleme yapılıp karar verilmesine olanak tanıyan bir usul hükmü de yoktur. Hal böyle olunca, mahkemeye verilen feragat dilekçesinin temyiz isteği kabul edilerek dosyanın Yargıtay'a sevkinin sağlanması, Yargıtay'ca verilen bozma ilamından sonra dosyanın ele alını feragat nedeniyle gerekli kararın verilmesi zorunludur. Yerleşmiş uygulama bu yöndedir..." (YKD 2003/7, s. 1033).

227 Atalı, Pekcantez Usul (n 1) 2013; Kuru, C. IV (n 8) 3565.

228 Yarg. 8. HD, 28.02.2017, E. 2016/10528, K. 2017/2702 “Karar kesinleşinceye kadar davadan feragatin mümkün olduğuna, 
Sonrasında, hakkında bozma kararı verilen dava dosyasının, yargılamayı gerçekleştirerek kararı veren ilk derece mahkemesine geri gönderilmesi sağlanmaktayd ${ }^{229}$. Yargıtay tarafından verilen bozma ilamından sonra davacının davadan feragat beyanı hakkında karar verilmek üzere dava dosyası kendisine gönderilen ilk derece mahkemesince feragat sebebiyle davaya son verilmekteydi ${ }^{230}$.

Görüldüğü üzere, Yargitay kararlarına yansıyan yerleşik uygulama pratik olmaktan oldukça uzaktı. Zira, doktrinde ileri sürülen görüşlerde, Yargitay uygulamasının yerinde olmadığı ifade edilerek söz konusu uygulama çeşitli açılardan eleştirilmekteydi ${ }^{231}$. Gerçekten de doktrinde ileri sürülen bir görüşe göre, hüküm verildikten sonra davadan feragat edilmesi durumunda, bu halin bir bozma sebebi olarak kabul edilmesinin uygun olmayacağı öne sürülmekteydi ${ }^{232}$. Bu doğrultuda, kanun yolu mahkemesi tarafından feragat sebebiyle dava dosyası hakkında karar verilmesine yer olmadığ 1 şeklinde bir hükmün tesis edilmesi isabetli bulunmamaktayd1 ${ }^{233}$. Bu sebeple de yüksek mahkemece karar verilmesine yer olmadığına hükmedilebilmesinin gerektiği ileri sürülmekteydi ${ }^{234}$.

Yine, doktrinde ileri sürülen diğer bir görüşe göre, Yargitay kararlarına yansıyan yerleşik uygulama, usul ekonomisi ilkesine (HMK m. 30; HUMK m. 77) ve menfaatler dengesine de aykırıyd ${ }^{235}$. Böylelikle, Yargıtay'in geçmişten beri benimsediği uygulamayı sürdürmek istemesinin herhangi bir amaca ve pratik gereklere uygun düşmediği ifade edilmekteydi ${ }^{236}$.

Yargıtay’n yerleşik içtihatlarında belirtilen şekilde yerel mahkemece karar verildikten sonra kanun yoluna müracaat edilmeden önce davacının yönelttiği feragat dilekçesinin temyiz talebi olarak kabul edilmesi kanaatimizce de isabetli değildi ${ }^{237}$. Zira, hukuk davalarında, hüküm verildikten sonra davadan feragatin Yargitay tarafindan bozma sebebi olarak kabul edilmesi usul yasalarına uygun olmamaktayd ${ }^{238}$. Ayrıca, feragat sebebiyle dava dosyasının kanun yolu mahkemesine gönderilerek

Mahkemece, bir karar verilip, davadan el çektikten sonra temyiz aşamasında davacı asil tarafindan davadan feragat edildiğine ve bu aşamada feragat hakkında karar verme yetkisi yerel mahkemeye ait bulunduğuna göre, davacının davadan feragat beyanı hakkinda bir karar verilmek üzere bozulması gerekmektedir" (e-uyar); www.hukukmedeniyeti.org). Yarg. 6. HD, 28.5.1974, E. 2305, K. 2568 “...kararlar daval vekili tarafindan temyiz edilmiştir. Hüküm taraflara henüz tebliği ve temyiz vaki olmadan davacı vekilleri A.S. mahkemeye verdiği 7.4.1971 günlü dilekçe ile davadan vazgeçtiğini bildirmiş, vekaletnameye göre adı geçen vekilin davadan feragata yetkili bulunduğu anlaşılmıştır. Temyiz vaki olmadan davadan feragat edildiğine göre bu hususta bir karar verme yetkisi Yargitay' a değil, mahalli mahkemesine ait olduğundan bu hususta bir karar verilmek üzere gerek esas hükmün ve gerekse sonradan ittihaz edilen ve feragat istemi hakkinda mahkemece bir karar verilemeyeceğine ilişkin kararın bozulması gerekmiştir." (Soner (n 11) 444-445).

229 Atal, Pekcanttez Usul (n 1) 2013.

230 Budak ve Karaaslan (n 1) N. 13, s. 322; Atal, Pekcanitez Usul (n 1) 2013.

231 Eleştiriler için bkz.: Budak ve Karaaslan (n 1) N. 13, s. 322; Atalı, Pekcanıtez Usul (n 1) 2013.

232 Budak ve Karaaslan (n 1) N. 13, s. 322.

233 ibid 322.

234 ibid 322.

235 Kuru, C. IV (n 8) 3567; Atal, Pekcanitez Usul (n 1) 2013.

236 Atal, Pekcanitez Usul (n 1) 2013.

237 Bkz:: Atal, Pekcanttez Usul (n 1) 2013; Budak ve Karaaslan (n 1) N. 13, s. 322. Bu konuda daha önce yazılmış bir çalışma için bkz.: Akil Önder 'Hukuk Davalarında Hüküm Lahik Olduktan Sonra Davadan Feragat Temyiz Mahkemesince Bozma Sebebi İttihaz Olunabilir Mi?' (1942) 7 AD 799-810.

238 Bu görüşteki yazarlar için bkz.: Atalı, Pekcanıtez Usul (n 1) 2013; Budak ve Karaaslan (n 1) N. 13, s. 322. Doktrinde Budak, temyiz incelmesi esnasında davadan feragat edilmesi durumunun bir bozma sebebi olmayacağı bu sebeple de 
sonrasında onun tarafından bozulması üzerine ilk derece mahkemesine tekrardan intikal ettirilmesi ve bundan sonra ilk derece mahkemesinin feragat sebebiyle karar vermesi ciddi bir zaman ve emek kaybı teşkil etmekteydi. Bu sebeple, Yargıtay tarafından benimsenen uygulama aynı zamanda usul ekonomisi ilkesine de aykırılık teşkil eden bir yöne sahipti ${ }^{239}$.

Doktrinde getirilen eleştiriler ve ileri sürülen görüşler bir tarafa, Yargıtay’ın geçmişten beri benimsediği uygulamanın mevcudiyetinde, Yönetmelik hükümleri ile getirilen düzenlemeler (eski HMK Yönetmeliği m. 57; Yazı İşleri Yönetmeliği m. 215) hükümden sonra ve fakat kanun yollarına müracaat edilmesinden önce davadan feragat şeklindeki beyanının ilk derece mahkemesince karara bağlanacağını öngörmek suretiyle oldukça farklı bir esas kabul etmekteydi ${ }^{240}$. Bu durum karşısında Yargitay, ilk zamanlarda verdiği kararlarda, Yönetmeliğin 215’inci maddesinde öngörülen ilk derece mahkemesince ek karar alınması gerektiği şeklindeki yönetmelik hükmünün (eski HMK Yönetmeliği m. 57) yürürlüğe girmesinden sonra da uzun zamandan beri sürdürdüğü uygulamanın devam etmesi gerektiği yönünde kararlar vermiştir ${ }^{241}$.

Yargıtay'a göre, hükmün verilmesinden sonra yargılamayı yürüten ilk derece mahkemesinin dosyayı tekrardan ele alması mümkün olmayacağından dosyanın Yargıtay’a gönderilmesi gerekmekteydi ${ }^{242}$.

kanun yolu mahkemesinin feragat sebebiyle dosya hakkında karar verilmesine yer olmadığına karar verebileceğini ileri sürmektedir. Bkz.: Budak ve Karaaslan (n 1) N. 13, s. 322.

239 Bu yöndeki eleştiriler için bkz.: Atalı, Pekcanttez Usul (n 1) 2015-2016; Kuru, C. IV (n 8) 3568.

240 Atall, Pekcantez Usul (n 1) 2013.

241 Yarg. 22. HD. 15.2.2016, E. 2015/19288, K. 2016/3686 “... Bir kısım işçilik alacaklarının ödetilmesi istemi ile açılan davada mahkemece davanın kısmen kabulüne ilişkin verilen karar, davalı ve davacı vekilleri tarafindan temyiz edilmiş ve dosya temyiz incelemesi için dairemize gönderilmiştir. Davacı vekili 09.02.2016 tarihli dilekçesi ile davadan ve temyizden feragat ettiğini bildirmiştir. 06.08.2015 tarihli ve 29437 sayıl Resmî Gazete’de yayımlanarak yürürlüğe giren, Bölge Adliye ve Adli Yargı İlk Derece Mahkemeleri ile Cumhuriyet Başsavcılıkları İdari ve Yazı İsleri Hizmetlerinin Yürütülmesine Dair Yönetmeliğin 215. maddesinde "Hükmün kesinleşmesinden önce davadan feragat, davayı kabul veya sulh halinde, hâkim dosya üzerinden bu konuda ek karar verir. Taraflarca kanun yoluna başvurulmuş olsa dahi sirf bu nedenlerle dosya istinaf veya temyiz incelemesine gönderilmez." düzenlemesi yer almaktadır. Anılan sebeple, hükümden sonra ortaya çıkan ve temyiz incelemesine usulen engel oluşturan davadan feragat beyanının mahkemece değerlendirilip karara bağlanması için dosyanın mahkemesine iadesine karar vermek gerekmiştir...”(Lexpera). Yarg. HGK. 14.06.2017 T. E. 4-1358, K. 1193 “Diğer taraftan normlar hiyerarşisi dikkate alındiğında daha alt basamakta yer alan ve tamamen idarenin düzenleyici tasarrufu niteliğinde olan yönetmelikle, daha üst basamakta bulunan ve yasama organı tarafından objektif, soyut ve genel nitelikte bir yasama tasarrufu niteliğinde bulunan kanuna aykırı düzenleme getirilmesi mümkün değildir. Yönetmelik kaynağını kanundan alır ve ancak kanunun uygulanmasını gösterir. Kanunda bulunmayan bir düzenlemenin, yönetmelikle ihdası ve bu yolla kanunun önüne geçen bir uygulamanın benimsenmesi hukukun genel teorisine de aykırıdır. Taraflar arasında daha önce görülen maddi tazminat istemli davada, daval ... hakkında verilen karar nihai bir karardır. Bu karar usulen temyiz edilip bozulmadan, mahkemece ortadan kaldırılarak başka bir karar verilemeyeceğine göre; temyiz süresi içinde davanın feragat dilekçesi vermesi üzerine, davanın yargı yolu sebebiyle reddine dair direnme kararının ortadan kaldırılması ile davanin reddine dair verilen 29.05.2014 tarihli ek karar yok hükmündedir (HGK, 24.06.2009 gün ve 2009/2-231 E., 2009/286 K.), Yukarıda açıklanan sebeplerle hükme bağlanıp hakimce el çekilen davaya, bir yönetmelik hükmüne istinaden hakimin tekrar bakabileceğinin kabulü mümkün değildir. Hal böyle olunca davalı ... hakkındaki davanın feragat sebebiyle reddine dair 29.04.2014 tarihli ek kararın kaldırılmasına oybirliği ile karar verilerek ikinci ön sorun da böylece aşılmıştır..." (e-uyar).

242 Yarg. 23. HD, 21.04.2016, E. 2015/8604, K. 2566 “...6100 sayılı HMK’da bu konuda açık bir düzenleme yapılmamış, ancak bu kanuna dayanılarak çıkarılan ve yeni yönetmeliğin yürürlüğe girdiği 06.08.2015 tarihine kadar yürürlükte bulunan Hukuk Muhakemeleri Kanunu Yönetmeliğinin "Karar verilmiş dosyalara ilişkin işlemler" başlıkl 57. maddesinde "Hükmün kesinleşmesinden önce davadan feragat, davayı kabul veya sulh halinde, hâkim dosya üzerinden bu konuda ek karar verir. Taraflarca kanun yoluna başvurulmuş olsa dahi sırf bu nedenlerle dosya istinaf veya temyiz incelemesine gönderilmez." 
Yine, Yargıtay kararlarında, yasada öngörülmemiş ve düzenlenmemiş bir hususta yönetmelik ile getirilen düzenlemeye üstünlük tanınamayacağı gerekçesiyle ilk derece mahkemesinin hükmünden sonra dosyayı ele alarak ek karar oluşturmasının yerinde olmadığı içtihat edilmekteydi ${ }^{243}$. Yargıtay’nn bu yöndeki kararlarından birinde bu husus açıkça ortaya konulmaktaydı:

“...Yerel mahkemece hükmün verilmesinden sonra, ancak henüz kesinleşmeden davacı davadan feragat ettiğine göre; yerel mahkemenin dosyayı tekrar ele alıp ek karar oluşturması ve önceki kararını değiştirmesi artık mümkün değildir. Bu durumda dosyanın Yargıtay’a gönderilmesi gerekir. Bu durumla ilgili mahkemeye yetki veren bir yönetmelik hükmü (Hukuk Muhakemeleri Kanunu Yönetmeliği m. 57) bulunduğu ileri sürülebilirse de; Hukuk Muhakemeleri Kanununda veya başka bir Kanunda öngörülmemiş ve düzenlenmemiş bir konuda yönetmelikle getirilen düzenlemeye üstünlük tanınamaz. O halde, mahkemenin hükümden sonra dosyayı ele alıp, ek karar oluşturması usul ve yasaya aykırıdır. Bu sebeple ek kararın bozularak kaldırılmasına karar verilmiştir..."244.

Görüldüğü üzere, Yargitay, HMK Yönetmeliği m. 57 hükmüyle getirilen ilk derece mahkemesince ek karar verilerek feragat sebebiyle davanın sona erdirilmesi yönündeki imkânı kabul etmemekte ve yerleşik uygulamasında ısrar etmekteydi ${ }^{245}$. Bu sebeple, Yargıtay tarafından Hukuk Muhakemeleri Kanunu Yönetmeliği’nin 57’nci maddesi ile ilk derece mahkemesine ek karar alma yetkisinin

düzenlemesi getirilmiştir. 06.08.2015 tarihinde yürürlüğe giren Bölge Adliye ve Adli Yargı İlk Derece Mahkemeleri ile Cumhuriyet Başsavcılıkları İdari ve Yazı İsleri Hizmetlerinin Yürütülmesine Dair Yönetmeliğin 215. maddesi de, aynı düzenlemeyi içermektedir. HMK'nın 5. kısım 3. bölümünde yer alan ve davaya son veren taraf işlemlerinden olan feragat 6100 sayılı HMK’nın 311/1. maddesi hükmü uyarınca, kesin hüküm sonuçlarını doğurduğu gibi, aynı Kanun’un $309 / 2$. maddesi uyarınca karşı tarafın kabulüne de bağlı bulunmamaktadır. Öte yandan, aynı Kanun'un 310/1. maddesi uyarınca davadan feragat kesinleşinceye kadar her aşamada mümkündür. Mahkeme davadan el çektiğinden, karar ortada durduğu müddetçe, davayı yeniden ele alıp, feragat nedeniyle bir karar veremez. (11.04.1940 gün ve 1939/15-70 sayılı İBK ile YHGK'nın 21.11.1981 gün ve 2 E., $551 \mathrm{~K}$. sayıl ilamı bu yöndedir.) YHGK’nın 19.12.2012 gün ve 13-1369 E., $1221 \mathrm{~K}$. sayll ilam ile Dairemizin 06.12.2013 tarih ve 5603 E., 7763 K; 29.09.2014 tarih ve 2028 E; 6027 K. sayıl ilamlarmda da açıklandığı üzere; 6100 sayılı HMK'da açık bir hüküm bulunmayan ve Içtihadı Birleştirme Kararı ile yöntemi belirlenmiş bir konuda, yönetmelik hükmüne dayalı olarak, hükümden sonra davanın ele alınması suretiyle ek karar tesis edilmesi doğru değildir. Bu durumda mahkemece, 23.10.2015 tarihli dilekçenin kooperatifi temsile yetkili kişiler tarafindan verildiğinin belirlenmesi ve kimlik tespitlerinin yapılması halinde asıl davadan feragat nedeniyle mahkemece bir karar verilmesi gerektiğinden, bunun sağlanabilmesi için hükmün öncelikle bu nedenle bozulması gerekmiştir...” (e-uyar).

243 Yarg. 2. HD, 25.9.2013, E. 2013/8562, K. 2013/21806 “... Taraflar arasindaki davanın yapilan muhakemesi sonunda mahalli mahkemece verilen, yukarıda tarihi ve numarası gösterilen hüküm, davalı tarafından 14.01.2013 tarihli ek karara yönelik olarak temyiz edilmekle, evrak okunup gereği görüşülüp düşünüldü: Mahkemece, 25.12.2012 tarihinde boşanma davasının esastan reddine, dava tarihinden geçerli olmak üzere daval yararına aylik 200 TL tedbir nafakasına hükmolunmasına karar verilmiş, hüküm henüz kesinleşmeden davacı 11.01.2013 günü verdiği dilekçesiyle davadan feragat ettiğini bildirmiş, bunun üzerine hakim, dosyayı ele alı, evrak üzerinden 14.01.2013 tarihinde ek kararı vermiştir. Ek kararla "davacı davasından feragat ettiğinden, esas hakkında karar verilmesine yer olmadiğına” şeklinde karar oluşturulmuştur. 1-Davadan feragat, kesin hükmün hukuki sonuçların hasıl eder. (HMK.m.311/1) Davacı, yerel mahkemece hüküm verilmesinden sonra henüz kesinleşmeden davadan feragat ettiğine göre, böyle bir durumda yerel mahkemenin dosyayı ele alıp ek karar oluşturması ve önceki kararını değiştirmesi artık mümkün değildir. Bu durumda dosyanın Yargıtay’a gönderilmesi gerekir. Yasada öngörülmemiş ve düzenlenmemiş bir hususta yönetmelikle getirilen düzenlemeye üstünlük tanınamaz. O halde, mahkemenin hükümden sonra dosyayı ele alıp, ek karar oluşturması usul ve yasaya aykırı bulunmuştur. 2-Kabule göre de; Davadan feragat, kesin hüküm hukuki sonuçlarını hasıl ettiğine (HMK.m.311/1) göre, ek kararın davanın feragat sebebiyle reddi yönünde olması gerekirken, davanın esası hakkında karar verilmesine yer olmadiğına şeklinde karar verilmesi de doğru olmamıştır..." (Lexpera).

244 Yarg. 2. HD, 01.12.2013, 23944/28255 (Lexpera; Aynı karar için bkz.: Atalı, Pekcanıtez Usul (n 1) 2013 - 2014 ).

245 Atalı, Pekcantez Usul (n 1) 2013. 
verilmesinin söz konusu olamayacağı içtihat edilmekteydi ${ }^{246}$. Buna karşılık, HMK Yönetmeliği m. 57’yi yürürlükten kaldıran Yazı İşleri Yönetmeliği’nin 215’inci maddesinde öngörülen düzenlemenin yürürlüğe girmesi ile birlikte, yakın zamanda Yargıtay’ın hükümden sonra ortaya çıkan ve kanun yolu incelemesine engel teşkil eden feragat nedeniyle yargılamanın sona erdiğini tespit eden kararı vermek üzere dosyanın ilk derece mahkemesine iade edilmesinin gerektiği yönünde kararlar verdiği görülmektedir ${ }^{247}$.

“...Bir kısım işçilik alacaklarının tahsili istemi ile açılan davada Mahkemece davanın kısmen kabulüne ilişkin verilen karar, bir kısım davalı vekili tarafindan temyiz edilmiş ve dosya temyiz incelemesi için Dairemize gönderilmiştir. Davacı asıl tarafından 06.07.2017 tarihli dilekçe ile davadan feragat edildiği bildirilmiştir. 06.08.2015 tarihli ve 29437 sayılı Resmî Gazete’de yayımlanarak yürürlüğe giren, Bölge Adliye ve Adli Yargı İlk Derece Mahkemeleri ile Cumhuriyet Başsavcılıkları İdari ve Yazı İşleri Hizmetlerinin Yürütülmesine Dair Yönetmeliğin 215. maddesinde "Hükmün kesinleşmesinden önce davadan feragat, davay kabul veya sulh halinde, hâkim dosya üzerinden bu konuda ek karar verir. Taraflarca kanun yoluna başvurulmuş olsa dahi sirf bu nedenlerle dosya istinaf veya temyiz incelemesine gönderilmez." düzenlemesi yer almaktadır. Anılan sebeple, hükümden sonra ortaya çıkan ve temyiz incelemesine usulen engel oluşturan davadan feragat beyanının Mahkemece değerlendirilip karara bağlanması için dosyanın mahkemesine iadesine karar vermek gerekmiştir..."248

HMK Yönetmeliği m. 57 düzenlemesinin var olduğu dönemde, Yargıtay tarafından eskiden beri süregelen uygulamanın devam ettirilmesi gerektiği konusunda israr edilmesi ${ }^{249}$ kanaatimizce isabetli değildi ${ }^{250}$. Bu sebeple, Yargıtay tarafından son dönemlerde verilen kararlarda Yönetmeliğin 215’inci

246 Atalı, Pekcanıtez Usul (n 1) 2013. Yargitay’ın bu yöndeki bir kararı için bkz.: Yarg. 22. HD, 6.6.2016, E. 2016/1701, K. 2016/16658 (Lexpera).

247 Yarg. 22 HD, 10.05.2018, E. 2017/15145, K. 2018/11650 “...Bir kısım işçilik alacaklarının tahsili istemi ile açılan davada Mahkemece verilen karar, temyiz edilmiş ve dosya temyiz incelemesi için Dairemize gönderilmiştir. Davacı vekili tarafindan 01.05.2018 tarihli dilekçe ile davadan feragat edildiği bildirilmiştir. Ancak davacı vekilinin dosyada mevcut vekaletname belgesinde davadan feragate yetkisinin bulunmadığı anlaşılmıştır. 06.08.2015 tarihli ve 29437 sayılı Resmî Gazete’de yayımlanarak yürürlüğe giren, Bölge Adliye ve Adli Yargı İlk Derece Mahkemeleri ile Cumhuriyet Başsavcılıkları İdari ve Yazı İşleri Hizmetlerinin Yürütülmesine Dair Yönetmeliğin 215. maddesinde "Hükmün kesinleşmesinden önce davadan feragat, davayı kabul veya sulh halinde, hâkim dosya üzerinden bu konuda ek karar verir. Taraflarca kanun yoluna başvurulmuş olsa dahi sırf bu nedenlerle dosya istinaf veya temyiz incelemesine gönderilmez." düzenlemesi yer almaktadır. Anılan sebeple, davacı vekilin dosyada mevcut vekaletname belgesinde davadan feragate yetkisinin bulunmadı̆̆ anlaşıldiğından, öncelikle davadan feragat yetkisini içeren vekaletname temin edilerek hükümden sonra ortaya çıkan ve temyiz incelemesine usulen engel oluşturan davadan feragat beyanının Mahkemece değerlendirilip karara bağlanması için dosyanin Mahkemesine iadesine karar vermek gerekmiştir..." (Lexpera).

248 Yarg. 22 HD, 07.07.2017, E. 2017/27972, K. 2017/16657 (Lexpera).

249 "Yerel mahkemece hükmün verilmesinden sonra, ancak henüz kesinleşmeden davacı davadan feragat ettiğine göre; yerel mahkemenin dosyayı tekrar ele alıp ek karar oluşturması ve önceki kararını değiştirmesi artık mümkün değildir. Bu durumda dosyanın Yargıtay'a gönderilmesi gerekir. Bu durumla ilgili mahkemeye yetki veren bir yönetmelik hükmü (Hukuk Muhakemeleri Kanunu Yönetmeliği m. 57) bulunduğu ileri sürülebilirse de; Hukuk Muhakemeleri Kanununda veya başka bir Kanunda öngörülmemiş ve düzenlenmemiş bir konuda yönetmelikle getirilen düzenlemeye üstünlük tanınamaz. $O$ halde, mahkemenin hükümden sonra dosyayı ele alıp, ek karar oluşturması usul ve yasaya aykırıdır. Bu sebeple ek kararın bozularak kaldırılmasına karar verilmiştir..." (Yarg. 2. HD, 01.12.2013, 23944/28255, Lexpera; Aynı karar için bkz.: Atalı, Pekcantez Usul (n 1) 2013-2014).

250 Doktrinde bu görüşte bkz.: Atalı, Pekcanttez Usul (n 1) 2013. 
maddesindeki uygulamaya riayet edilerek, dosyanın ilk derece mahkemesine gönderilmesi gerektiği hususunun ifade edilmesi kanaatimizce daha isabetli olmuştur.

\section{725I SAYILI KANUN DEĞIŞIKLIĞINDEN SONRAKI DURUM: HMK M. 310 HÜKMÜNDE ÖNGÖRÜLEN YENI DÜZENLEMELER}

28.07.2020 tarihli ve 7251 sayılı Hukuk Muhakemeleri Kanunu ile Bazı Kanunlarda Değişiklik Yapılması Hakkında Kanun değişikliği sonrasında, davadan feragatin zamanına ilişkin olarak Yazı İşleri Yönetmeliği’nin 215'inci ${ }^{251}$ maddesi (eski HMK Yönetmeliği m. 57) ile Yargıtay’ın son dönemde verdiği kararlarda kabul edilen prosedür ${ }^{252} \mathrm{HMK}^{\prime}$ ya eklenerek kanun hükmü haline getirilmiştir ${ }^{253}$. Kanun koyucu, HMK m. 310 hükmünde gerçekleştirdiği değişikliklerle, feragatin yapılma zamanı ile davadan feragat üzerine mahkemelerce verilecek olan karar hakkında çeşitli yenilikler meydana getirmiştir ${ }^{254}$. Bu kapsamda, 7251 sayılı Kanun ile HMK m. 310 hükmüne iki yeni fıkra eklenerek ${ }^{255}$ ilgili madde revize edilmiştir ${ }^{256}$.

HMK m. 310 hükmüne 7251 sayılı Kanun değişikliği ile eklenen 2’nci ${ }^{257}$ fıkraya göre, davadan feragat hükmün verilmesinden sonra gerçekleştirilmişse, yargılamanın taraflarınca kanun yoluna müracaat edilmiş olsa bile, dosyanın kanun yolu incelemesine gönderilmeyeceği ve ilk derece mahkemesi veya bölge adliye mahkemesince feragat doğrultusunda "ek karar" verileceği hükme bağlanmıștır ${ }^{258}$, Görüldüğü üzere, mahkemece verilecek olan nihai karardan sonra davacı tarafından davadan feragat edilmesi gerek ilk derece yargılamasında gerekse de istinaf kanun yolunda mümkün olabilecektir ${ }^{259}$.

Şayet, mahkemece nihai karar verilerek dosyadan el çekildikten sonra, davadan feragat edilirse, dava dosyası, istinaf incelemesi için bölge adliye mahkemesine gönderilmez ve ilk derece mahkemesince - davadan el çekilmiş olsa bile - feragat sebebiyle ek karar verilerek dava sonlandırılır ${ }^{260}$. Görüldüğü üzere, HMK m. 310 f. 2 ile getirilen düzenleme sayesinde, feragat talebinde bulunulan dava dosyasinın

251 Yazı İşleri Yönetmeliği m. 215 hakkındaki açıklamalarımız için bkz.: yuk. II, A, 1, b, bb.

252 Yargıtay’ın davadan feragatin zamanına ilişkin olarak ortaya koyduğu kararlar hakkında bkz.: yuk. I, D.

253 Budak ve Karaaslan (n 1) N. 13, s. 322. Ayrıca, davadan feragatin zamanı konusunun Yargitay kararlarıyla ve uygulamada ortaya konulduğu hakkındaki eleştiriler için bkz.: Hakan Pekcanıtez, Oğuz Atalay ve Muhammet Özekes, 'Hukuk Muhakemeleri Kanunu ile Bazı Kanunlarda Değişiklik Yapılmasına Dair Kanun Teklifinin (2020) Değerlendirilmesi', LexperaBlog, (30.03.2020) <https://blog.lexpera.com.tr/hmk-ile-bazi-kanunlarda-degisiklik-yapilmasina-dair-kanunteklifinin-2020-degerlendirilmesi/> (Son Erişim Tarihi: 29.07.2020).

254 Öztek, Taşpınar Ayvaz ve Kale (n 32) 138.

$255 \operatorname{Karsl}_{1}$ (n 1) 374.

256 Bkz.: 7251 sayılı Kanun değişikliğinden sonraki HMK m. 310 f. 2 ve f. 3.

257 HMK m. 310/f. 2 hükmü aynen şu şekildedir: "Feragat veya kabul, hükmün verilmesinden sonra yapılmışsa, taraflarca kanun yoluna bașvurulmuş olsa dahi, dosya kanun yolu incelemesine gönderilmez ve ilk derece mahkemesi veya bölge adliye mahkemesince feragat veya kabul doğrultusunda ek karar verilir." (Ek fikra, 28.07.2020 tarihli 7251 sayılı Kanun m. 29).

258 Öztek, Taşpınar Ayvaz ve Kale (n 32) 138; Tanrıver, Medenî Usûl C. I (n 16) 1047; Kuru ve Aydın (n 145) 399; Arslan, Yılmaz, Taşpınar-Ayvaz ve Hanağası, (n 13) 566; Budak ve Karaaslan (n 1) N. 13, s. 322; Karslı (n 1) 374; Atalı, Ermenek ve Erdoğan (n 1) 575; Görgün, Börü, Toraman ve Kodakoğlu (n 6) 598.

259 Öztek, Taşpınar Ayvaz ve Kale (n 32) 138.

260 Arslan, Yılmaz, Taşpınar-Ayvaz ve Hanağası, (n 13) 566. 
kanun yolu mahkemesine gönderilmeden sonlandırılmasının önü açılarak emek ve zaman kaybının yaşanmasına engel olunmuştur ${ }^{261}$.

7251 sayılı Kanunla HMK m. 310’da gerçekleştirilen değişikliklerin temelde Yazı İşleri Yönetmeliği m. 215 ile Yargitay kararlarıyla şekillenen uygulamada var olan durumu yansıttığı söylenebilecektir. Doktrinde bazı yazarlarca, HMK m. 310 hükmünde gerçekleştirilen değiş̧ikliklerin uygulamada ve Yargitay kararlarında öngörülen durumun kanuna eklenmesinden ibaret olduğu ileri sürülerek eleştirilmektedir ${ }^{262}$. Bununla birlikte, HMK m. 310 hükmünde gerçekleştirilen değişikliklerin bilineni ortaya koyduğu ve gereksiz olduğunun ileri sürülmesi kanaatimizce isabetli değildir263. Diğer bir deyişle, kanun koyucunun öngördüğü değişikliklerin tamamen gereksiz olduğunu ifade etmek doğru olmayacaktır. Zira, hükümden sonra feragat konusunda HMK m. 310/f. 2 hükmünün kabul edilerek yönetmelikle getirilen düzenlemelere kanuni bir dayanak sağlanmış olması önem arz etmektedir. $\mathrm{Bu}$ sayede, hukuk yapma tekniği bakımından önemli bir eksikliğin giderilmesi söz konusu olmuştur. Aynı zamanda, doktrinde ileri sürülen tartışmalara HMK m. 310 hükmünde düzenleme getirilmek suretiyle bir son verilmiştir.

\section{B. KANUN YOLLARI AŞAMASINDA DAVADAN FERAGAT VE DAVANIN FERAGAT SEBEBIYLE SONA ERDIĞINI ORTAYA KOYACAK OLAN MERCI}

Hükümden sonra, taraflarca kanun yollarına müracaat edilmesi durumunda, kanun yolları aşamasındaki bir davadan feragat ${ }^{264}$ edilmesi üzerine hangi merci tarafından karar verileceği hususunun değerlendirilmesi gerekmektedir ${ }^{265}$. Bu kapsamda, öncelikle istinaf kanun yolundaki bir

261 Öztek, Taşpınar Ayvaz ve Kale (n 32) 138. Yargıtay’n yerleşik uygulamasında öngörülen şekilde davadan feragat edilmesine rağmen dosyanın kanun yolu mahkemesine gönderilerek üst derece mahkemesince verilecek olan kararın beklenmesi şeklindeki prosedürün önüne geçilmiştir (Öztek, Taşpınar Ayvaz ve Kale (n 32) 138). Yargitay’n hükümden sonra davadan feragate ilişkin yönetmelik hükümlerinin (eski HMK Yönetmeliği m. 57; Yazı İșleri Yönetmeliği m. 215) yürürlüğe girmesinden önceki yerleşik uygulaması için bkz.: yuk. II, A, 1, c, bb.

262 Hakan Pekcanıtez, Oğuz Atalay ve Muhammet Özekes, 'Hukuk Muhakemeleri Kanunu ile Bazı Kanunlarda Değişiklik Yapılmasına Dair Kanun Teklifinin (2020) Değerlendirilmesi', LexperaBlog, (30.03.2020) <https://blog.lexpera.com.tr/ hmk-ile-bazi-kanunlarda-degisiklik-yapilmasina-dair-kanun-teklifinin-2020-degerlendirilmesi/> (Son Erişim Tarihi: 29.07.2020).

263 Öztek, Taşpınar Ayvaz ve Kale (n 32) 138.

264 Kanun yolları aşamasında davadan feragat ile kanun yollarından feragat sıklıkla karıştırılan ve kimi zaman da birbirlerinin yerine kullanılan kavramlardır. Oysaki, kanun yolları aşamasında davadan feragat kavramı, kanun yollarından feragat kavramından farklılık arz etmektedir (Kanun yollarından feragat hakkında kapsamlı açıklamalar için bkz.: İbrahim Ercan ve İbrahim Özbay, 'Medeni Usul Hukukunda Kanun Yollarından Feragat' (2006) X (3-4) Erzincan Üniversitesi Hukuk Fakültesi Dergisi 433-458). Kanun yollarından feragatte, taraflarca kanun yoluna müracaat talebinin geri alınması kastedilmektedir (Ercan ve Özbay (n 264) 434; Kuru, C. V (n 189) 4494). Ayrıca, hüküm verildikten sonra taraflarca kanun yollarına müracaat hakkından feragat mümkündür (Ercan ve Özbay (n 264) 446). Bununla birlikte, taraflarca temyiz yoluna müracaat hakkı doğmadan, temyizden feragat edilmesi geçerli değildir (Kuru, $C . V$ (n 189) 4491). Diğer taraftan, konumuz olan temyiz aşamasında davadan feragatte, ilk derece mahkemesince kararın verilmesinden sonra temyiz aşamasına gelmiş olan bir davadan (ve böylelikle davaya konu olan haktan) feragat edilmesi söz konusudur. Böyle bir durumda, yukarıda da ifade ettiğimiz üzere, derdest bir dava söz konusu olduğu için kanun yolları aşamasında (istinaf veya temyiz) davadan feragat edilmesinde kural olarak herhangi bir engel bulunmamaktadır (Ansay (n 6) 183; Berkin (n 110) 751; Bilge (n 2) 310; Kuru, C. IV (n 8) 3570; Üstündağ (n 6) 571).

265 lk derece mahkemesinin kararını vermesi üzerine taraflarca kanun yollarına müracaat edildiği bir aşamada da 
davadan feragat edilmesi izah edilerek sonrasında, temyiz aşamasındaki bir davadan feragat konusu ele alınacaktır. Böylelikle, istinaf ve temyiz kanun yollarındaki bir davanın feragat sebebiyle sona erdiğini ortaya koyacak olan merciin neresi olduğu ile mahkemece verilecek olan karar hakkında açıklamalarda bulunulacaktır.

\section{ISTINAF KANUN YOLU AŞAMASINDA DAVADAN FERAGAT VE DAVANIN FERAGAT SEBEBIYYLE SONA ERDIĞINI TESPIT EDEN KARARI VERECEK OLAN MERCi}

Bölge adliye mahkemelerinin 20 Temmuz 2016 tarihinde göreve başlamasından sonra ${ }^{266}$, adli yargı teşkilatının içerisinde yer alan hukuk mahkemelerindeki iki dereceli yargı sistemi yerini üç dereceli yargı sistemine bırakmışıır ${ }^{267}$. İlk derece mahkemesince verilen kararların kanun yolu denetimi ilk olarak istinaf mahkemesi olan bölge adliye mahkemesince değerlendirilecektir ${ }^{268}$. İstinaf kanun yoluna müracaat eden taraf, yerel mahkemece verilen kararın hatalı, eksik veya yanlış olduğunu ileri sürerek kendi lehine hüküm tesis edilmesini talep edebilecektir ${ }^{269}$.

Taraflardan herhangi birinin ilk derece mahkemesince verilen kararı, istinaf kanun yoluna götürmüş olması durumunda, henüz şekli anlamda kesin hüküm teşkil etmediği için davadan feragat yoluna gidilebilmesi mümkündür ${ }^{270}$ (HMK m. 310/f. 1). Böyle bir durumda, davacı istinaf aşamasında davadan feragat etmek isterse, feragat beyanını bölge adliye mahkemesine iletir ${ }^{271}$.

İlk derece mahkemesince verilen hükmün istinaf kanun yoluna götürüldüğü bir aşamada, davadan feragat edilirse, dosya kendisinde olan bölge adliye mahkemesi, davanın feragat sebebiyle sona erdiğini tespit eden kararı verir ${ }^{272}$. Bu husus, 7251 sayılı Kanun değişikliği ile Hukuk Muhakemeleri

davadan feragat edilmesi mümkündür (Akyol Aslan (n 2) 263; Atalı, Ermenek ve Erdoğan (n 1) 574-575). Yarg. 15 HD, 20.1.2015, E. 2014/6936, K. 2015/256 “...Kanunun 310.maddesinde feragatin hükmün kesinleşmesine kadar her aşamada yapılabileceği ve 311.maddesinde ise feragatin kesin hüküm gibi sonuç doğuracağı hususları düzenlenmiş bulunmaktadır. Bir başka deyişle feragat yargılama devam ederken yapılabileceği gibi, hüküm verildikten sonra, karar temyiz edilmeden ya da temyiz edildikten sonra da yapılabilecektir..." (Lexpera). Uygulamada, temyiz aşamasındaki bir davadan feragat edilmesi durumunda, Yargıtay’a verilecek olan feragat dilekçesinin altındaki imzanın davacıya ait olup olmadığının anlaşlabilmesi için hâkim veya noter tarafından feragat dilekçesine şerh verilmiş olması gerekmektedir (Kuru, C. IV (n 8) 3574). Doktrinde Kuru, görüşünü desteklemesi bakımından Yargıtay’ı şu kararını örnek olarak göstermektedir. Yarg. 2. HD, 13.6.1977, 4721/4847 “...Dava boşanma davası olup, "dava reddedilmiş, davacı hükmü temyiz etmiş, temyiz dilekçesinde davasından vazgeçmiştir. Bu bakımdan konusu ortadan kalkan dava reddedilmek için hükmün bozulması icabeder. Ancak, bu durum yeniden duruşma yapılmasın gerektirmez. Onun için kararının düzelterek onanması uygun düşer..." (Kuru, C. IV (n 8) 3573).

266 Atalı, Ermenek ve Erdoğan (n 1) 602. Adalet Bakanlığının 7.11.2015 tarihli ve 29525 sayılı Resmî Gazetéde yayınlanan "Bölge Adliye Mahkemelerinin ve Bölge İdare Mahkemelerinin Tüm Yurtta Göreve Başlayacakları Tarihe İlişkin Karar" uyarınca 20.07.2016 tarihinde bölge adliye mahkemeleri göreve başlamıştır (Budak ve Karaaslan (n 1) N. 13, s. 370).

267 Görgün, Börü, Toraman ve Kodakoğlu (n 6) 648.

268 Atalı, Ermenek ve Erdoğan (n 1) 602.

269 Cenk Akil, İstinaf Kavramı (1. Bası, Yetkin 2010) 340. Ayrıca, istinaf kavramı hakkında bkz.: Tolga Akkaya, Medeni Usul Hukukunda İstinaf (1. Bas1, Yetkin 2009) 53 vd.; Ejder Yllmaz, İstinaf (2. Bs., İstanbul, Yetkin 2005) $21 \mathrm{vd.}$

270 Hatice Didem Sanıvar, Türk Medeni Yargılama Hukukunda Davadan Feragat (Marmara Üniversitesi Sosyal Bilimler Enstitüsü, Yayımlanmamış Yüksek Lisans Tezi, 2017) 45.

271 Akyol Aslan (n 2) 264 vd.; Karslı (n 1) 374.

272 Akkaya (n 269) 336. 
Kanunu'nun 310'uncu maddesinin 2'nci fikrasında açıkça düzenlenmiştir. Zira, Hukuk Muhakemeleri Kanunu m. 310/f. 2 hükmünde açıkça, "Feragat veya kabul, hükmün verilmesinden sonra yapılmışsa, taraflarca kanun yoluna başvurulmuş olsa dahi, dosya kanun yolu incelemesine gönderilmez ve ilk derece mahkemesi veya bölge adliye mahkemesince feragat veya kabul doğrultusunda ek karar verilir." denilmektedir. Görüldüğü üzere, dosyanın istinaf kanun yolunda incelendiği bir esnada davadan feragat edilirse, 7251 sayılı Kanun değişikliği ile şekillenen HMK m. 310/f. 2 uyarınca, aynı zamanda bir hüküm mahkemesi olan bölge adliye mahkemesi ${ }^{273}$, dava dosyasını geri göndermeyerek yargilamanın feragat sebebiyle sona erdiğini ortaya koyan bir ek karar verir ${ }^{274}$.

Ayrıca, ilk derece mahkemesi tarafından verilen hüküm, bölge adliye mahkemesince istinaf denetimine tabi tutulduktan sonra, bir de temyiz kanun yoluna müracaat edilmişse, dosyanın istinaf mahkemesinde bulunduğu - yani henüz Yargitay’a gönderilmediği - bir aşamada davadan feragat yoluna gidilirse, yargılamanın feragat sebebiyle sona erdiğini tespit eden kararı verme yetkisi bölge adliye mahkemesinde olur ${ }^{275}$. Diğer bir ifadeyle, 7251 sayılı Kanun değişikliği ile öngörülen HMK m. 310/f. 2 uyarınca, bölge adliye mahkemesince nihai kararın verilmesinden sonra ve fakat temyiz kanun yoluna müracaat edilmesinden önce davadan feragat edilirse, bu konuda bölge adliye mahkemesince ek karar verilerek yargılama sonlandırılır ${ }^{276}$.

\section{TEMYIZ KANUN YOLU AŞAMASINDA DAVADAN FERAGAT VE DAVANIN FERAGAT SEBEBIYYL SONA ERDIĞINI TESPIT EDEN KARARI VERECEK OLAN MERCi}

Bölge adliye mahkemelerinin fiilen çalışmaya başlamasıyla birlikte, istinaf mahkemelerince verilen kararlara karşı temyiz kanun yoluna gidilebilir ${ }^{277}$. Temyiz aşamasındaki bir davadan feragat edilmesi durumunda, davadan feragat etmek isteyen davacının, feragat dilekçesini Yargitay’a vermesi gerekir $^{278}$.

7251 sayılı HMK değişikliğinden öneki uygulamada, temyizden sonra davacı tarafından davadan feragat edilmesi üzerine, Yargıtay tarafından ilk derece mahkemesinin verdiği kararın feragat sebebiyle bozulması söz konusu olmaktaydı ${ }^{279}$. Zira, Yargıtay’a göre, feragat beyanı, temyiz

273 Bilindiği üzere, İstinaf aşamasında, bölge adliye mahkemesi, ilk derece mahkemesince verilen kararı hem hukuka uygunluk hem de olaya uygunluk bakımından denetleyebilecektir (Akil (n 269) 205).

274 Arslan, Yılmaz, Taşpınar-Ayvaz ve Hanağası, (n 13) 566; Karslı (n 1) 374.

275 Sanivar (n 270) 47; Akyol Aslan (n 2) 267.

276 Öztek, Taşpınar Ayvaz ve Kale (n 32) 138.

277 Atal, Ermenek ve Erdoğan (n 1) 634. Hukuk Muhakemeleri Kanunu’na göre, bölge adliye mahkemelerinden verilen ve belli bir meblağı aşan usule ve esasa ilişkin bütün nihai kararlar ile hakem kararlarının iptali talebi üzerine verilecek olan kararlar aleyhine temyiz kanun yoluna (HMK m. 361-374) müracaat edilebilecektir (Atalı, Ermenek ve Erdoğan (n 1) 634-635; Karsli (n 1) 799).

278 Karslı (n 1) 374.

279 Kuru, C. IV (n 8) 3570; Atall, Pekcantez Usul (n 1) 2014. HGK 18.11.1967, E. 8/437, K. 546, "Davact yararna olan bir hüküm davalının temyizi üzerine Yargıtay'da incelenmekte iken davacı esas davadan vazgeçtiği taktirde hüküm Yargıtay'ca bozulmalidır...” (Soner (n 11) 445). 4. HD, 19.12.1985, 9159/10179, “...davacı taraf temyiz aşamasında davadan feragat ettiğinden bu feragat karşı tarafin kabulüne bağlı bulunmadığından hükmün bozulmasına ve mevcut feragat gereğince işlem yapılmak üzere dosyanın mahalline gönderilmesine karar vermek gerekmiştir. Sonuç: Temyiz olunan hükmün yukarıdaki 
incelemesine usulen engel teşkil edeceği için feragat konusunda karar verme yetkisi hükmü veren mahkemeye ait olacaktı ${ }^{280}$. Bu sebeple, Yargitay tarafından ilk derece mahkemesince davadan feragat hakkında bir karar verilebilmesi amacıyla hükmün bozulması yönünde kararlar verilmekteydi ${ }^{281}$. Yargıtay'ın bu yöndeki kararlarından birisinde bu husus şu şekilde açıklanmaktaydı:

“...Karar kesinleşinceye kadar davadan feragatin mümkün olduğuna, Mahkemece, bir karar verilip, davadan el çekildikten sonra temyiz aşamasında davacı tarafindan davadan feragat edildiğine ve bu aşamada feragat hakkında karar verme yetkisi yerel mahkemeye ait bulunduğuna göre, davacının davadan feragat beyanı hakkında bir karar verilmek üzere hükmün bozulması gerekmektedir. Açıklanan nedenle, davacının davadan feragatı dikkate alınmak suretiyle davadan feragat ile ilgili hüküm kurulmak üzere yerel mahkeme kararının 6100 sayıl HMK'nun Geçici 3. maddesinin yollamasıla 1086 sayıl HUMK'nun 428. maddesi uyarınca BOZULMASINA..." 282.

Görüldügü üzere, 7251 sayılı Kanun değişikliğinden önce uygulamada temyiz aşamasında bulunan bir davadan feragat edilmesi halinde karar, Yargitay tarafından bozularak ilk derece mahkemesine gönderilmekteydi. Böylelikle, kararı veren ilk derece mahkemesine davacının feragat beyanında bulunması sebebiyle davanın sona erdiğini tespit eden kararı verebilme imkânı sağlanmaktaydı ${ }^{283}$.

nedenlerle mahkemece davanın reddine karar verilmek üzere bozulmasına karar verildi." (Kazancı İçtihat Bilgi Bankası; Kuru, C. IV (n 8) 3572).

280 Yarg. 3. HD, 31.10.2013, 12136/15008 “...Hükmün kesinleşmesinden önceki herhangi bir aşamada davadan feragat edilebilir. Ancak, hükümden sonra ortaya çıkan ve temyiz incelemesine usulen engel oluşturan feragat hakkında bir karar verme yetkisi ise hükmü veren mahkemeye aittir. Bu itibarla, mahkemece davadan karar verilmek üzere hükmün bozulmasına ve peşin alınan temyiz harcının istek halinde temyiz edene iadesine, 31.10.2013 tarihinde oybirliğiyle karar verildi..." (Lexpera; Aynı karar için ayrıca bkz.: Atalı, Pekcanıtez Usul (n 1) 2014).

281 Kuru, C. IV (n 8) 3570. Yarg. 1. HD, 27.09.2012, 9315/10217 “...Ne var ki, davacılar vekili temyiz aşamasında sunmuş olduğu 06.09.2012 havale tarihli dilekçesi ile davadan feragat ettiklerini bildirmiştir. Bilindiği üzere; 6100 sayıl HMK’nin 311. maddesinde feragatin kesin hüküm gibi hukuki sonu doğuracağl, 310. maddesinden ise hüküm kesinleşinceye kadar her zaman davadan feragat edilebileceği düzenlenmiştir. Hal böyle olunca, davacılar vekilinin feragat beyanının değerlendirilmesi ve sonucuna göre bir karar verilmesi gereklidir. Davalı vekilinin temyiz itirazları yerindedir. Kabulüyle, duruşma istemi bozma gereğine yerinde görülmeyip, davadan feragat nedeniyle bir karar verilmek üzere hükmün (6100 sayılı Yasanın geçici 3. maddesi yollaması ile) 1086 sayılı HUMK’nin 428. Maddesi gereğince bozulmasına...” (Lexpera; Aynı karar için ayrıca bkz.: Atalı, Pekcanttez Usul (n 1) 2015).

282 Yarg. 8 HD, 24.10.2016, E. 2016/14015, K. 2016/14411 (Lexpera).

283 Atalı, Pekcanıtez Usul (n 1) 2015. Yarg. 10. HD, E. 2017/3255, K. 2017/7426, 31.10.2017 “...Çekişmeli yargıda kural olarak, "tasarruf ilkesi” geçerlidir ve taraflar dava konusu üzerinde serbestçe tasarrufta bulunabilirler. Bu suretle davaya son verilebilmesinin bir yöntemi davadan feragattir ve anılan kurum 6100 sayıl Hukuk Muhakemeleri Kanunu'nun 307 ila 312. maddelerinde (mülga 1086 sayıl Hukuk Usulü Muhakemeleri Kanununun 91 ila 94. maddelerinde) düzenlenmiştir. Hükmün kesinleşmesinden önceki herhangi bir aşamada davadan feragat edilebilir. Temyiz edilen ve fakat henüz temyiz Dairesince görüşülmeyen bir karar, usul hukuku çerçevesinde kesinleşmiş olmadiğından, bu aşamada davadan feragat mümkündür. Hâkim, gördüğ̈̈ davada tahkikatı bitirip hüküm kurduktan sonra davadan elini çekmiş olur ve kural olarak dava sonunda verilen karar temyiz edilip bozulmadan ve bu suretle yargılamaya yeniden başlanmadan davanın esası ile ilgili hiçbir karar veremez. Feragat, davayı kesin olarak sonuçlandıran bir hukuki neden olduğundan, hâkim karar verdikten sonra dahi belgelendirilen feragat üzerine davanın bu nedenle reddine karar verebilir ise de, Yargitay uygulamalarında (örneğin Hukuk Genel Kurulunun 21.10.1981 gün 1981/2-551, 1981/683 ve 02.06.1982 günlü 1982/376-547 sayıl Kararları ile 11.04.1940 gün ve 1939/15-1940/70 sayıl tevhidi içtihat Kararının gerekçesinden esinlenen uygulama) hüküm temyiz edildikten sonra vaki feragat üzerine mahkemece kendiliğinden bir karar verilmeyerek Yargitay'in bu konuda (feragat konusunda) mahkemece bir karar verilmek üzere hükmün bozulmasına dair verilecek kararından sonra ancak dosyayı ele alabilir ve feragate dayanarak davayı reddedebilir. Bu itibarla, somut olayda davacının temyiz aşamasında verdiği dilekçe ile feragat edildiğini açıkça ve koşulsuz olarak bildirdiğinden, hükümden sonra ortaya çıkan ve temyiz incelenmesine usulen 
Yine, dosyanın temyiz aşamasında bulunduğu bir esnada, öncelikle davadan feragat edilip sonrasında feragatten vazgeçildiğinde de gerek davadan feragat gerekse de feragatten vazgeçme beyanları hakkında ilk derece mahkemesince karar verilebilmesi için Yargıtay tarafından hükmün bozulması söz konusu olmaktaydı ${ }^{284}$.

7251 sayılı Kanun değişikliğinden önceki uygulama uyarınca, temyiz incelemesi sırasında davadan feragat edilmesi sebebiyle, Yargitay tarafından bozularak kendisine gönderilen dosya hakkında ilk derece mahkemesince, yeniden yargılama yapılmamaktaydı ${ }^{285}$. Böyle bir durumda, ilk derece mahkemesi tarafından, davanın feragat sebebiyle reddi yönünde kararlar verilmekteydi ${ }^{286}$.

7251 sayılı Kanun'un 29’uncu maddesi ile gerçekleştirilen değişiklikle birlikte, dosyanın temyiz kanun yoluna gönderilmesinden sonra davadan feragat edilmesi hakkında Hukuk Muhakemeleri Kanunu’nda yeni bir düzenleme getirilmiştir. Böylelikle, Hukuk Muhakemeleri Kanunu’nun 310'uncu maddesinin 3'ncu fikrasında temyiz kanun yolunda davadan feragat bahsi açıkça ele alınmıştır. Hukuk Muhakemeleri Kanunu m. 310/f. 3 hükmünde kanun koyucu tarafından açıkça, "Feragat veya kabul, dosyanın temyiz incelemesine gönderilmesinden sonra yapılmışsa, Yargıtay temyiz incelemesi yapmaksızın dosyay feragat veya kabul hususunda ek karar verilmek üzere hükmü veren mahkemeye gönderir.” denilmektedir.

Görüldüğ̈̈ üzere, 7251 sayılı Kanunla HMK’nın 310’uncu maddesinin 3’üncü fikrasına yapılan ekleme neticesinde, temyiz kanun yolunda davadan feragat edilmesi söz konusu olduğunda, Yargıtay tarafından temyiz incelenmesi gerçekleştirilmeksizin dosyanın feragat hakkında ek karar verilmek üzere hükmü veren mahkemeye ${ }^{287}$ gönderilmesi gerekmektir ${ }^{288}$. Dikkat edilirse, 7251 sayılı Kanunla gerçekleştirilen değişiklikle, kanun koyucu tarafından temyiz aşamasındaki davadan

engel oluşturan bu hukuki olgu çerçevesinde, yeniden inceleme yapılmak üzere mahkeme hükmünün bozulmasına karar verilmesi gerekmektedir. O hâlde, hükmü temyiz eden davacı vekilinin bu yönleri amaçlayan temyiz itirazları kabul edilmeli ve ... Bölge Adliye Mahkemesi 10. Hukuk Dairesinin istinaf başvurusunun reddine ilişkin kararının kaldırılarak İlk Derece Mahkemesince verilen hüküm bozulmalıdır..” (Lexpera).

284 Yarg. 8. HD, 4.10.2016, E. 2016/13988, K. 2016/13086 “...HMK’nun 310. maddesine göre davadan feragat, hüküm kesinleşinceye kadar her zaman yapılabilir. HMK’nun 311. maddesinde ise feragatin kesin hüküm gibi hukuki sonuç doğuracă̆ 1 ve irade bozukluğu hallerinde feragat ve kabulün iptali istenebileceği belirtilmiştir. Karar kesinleşinceye kadar davadan feragatin mümkün olduğuna, Mahkemece, bir karar verilip, davadan el çekildikten sonra temyiz aşamasında davacı asıl tarafindan önce davadan feragat edilip sonra feragatten vazgeçildiğine, bu aşamada feragat hakkında karar verme yetkisi yerel mahkemeye ait bulunduğuna göre, davacı asılın davadan feragat ve feragatten vazgeçme beyanları hakkında bir karar verilmek üzere hükmün bozulması gerekmektedir." (Lexpera).

285 Kuru, C. IV (n 8) 3573.

286 Kuru, C. IV (n 8) 3573. Doktrinde Kuru, temyizden sonra feragat halinde, Yargitay’ın ilk derece mahkemesinin hükmünü bozarak tekrardan kendisine göndermesi yerine, "feragat nedeniyle davanın reddine" şeklinde değiştirerek ve düzelterek onamasının daha isabetli olacağını ifade etmektedir (Kuru, C. IV (n 8) 3573).

287 Yani, dosya Yargitay tarafindan kural olarak, istinaf mahkemesine veya başvurunun esastan reddi kararı üzerine temyiz edilen istinaf kararı ise ilk derece mahkemesine gönderilecektir (Arslan, Yılmaz, Taşpınar-Ayvaz ve Hanağası, (n 13) 566-567).

288 Öztek, Taşpınar Ayvaz ve Kale (n 32) 138; Arslan, Yılmaz, Taşpınar-Ayvaz ve Hanağası, (n 13) 566; Tanrıver, Medenî Usûl C. I (n 16) 1047; Karslı (n 1) 374; Budak ve Karaaslan (n 1) N. 13, s. 322; Atalı, Ermenek ve Erdoğan (n 1) 575; Görgün, Börü, Toraman ve Kodakoğlu (n 6) 598. 
feragat hususunda uygulamada var olan durum kanun maddesi haline getirilmiştir ${ }^{289}$. Bununla birlikte, kanun koyucu, HMK m. 310/f. 3’te öngördüğü düzenleme ile şimdiye kadar ki Yargitay uygulamasından bir yönüyle farklılaşmıştır. Zira, bu zamana kadar ki Yargıtay uygulamasında, temyiz kanun yolunda davadan feragat edilmesi üzerine hüküm Yargitay tarafından bozularak kararı veren ilk derece mahkemesine gönderilmekteydi ${ }^{290}$. Oysaki, günümüze kadar ki uygulamanın aksine, Yargıtay tarafından feragat beyanı üzerine bozma kararı verilmesi, HMK m. 310/f. 3 ile uygun bulunmamıştır ${ }^{291}$. Diğer bir ifadeyle, Yargitay, HMK m. 310/f. 3’te öngörülen düzenleme sonrasında yerleşik uygulamasında olduğu gibi hükmü bozmayacaktır ${ }^{292}$. Zira, madde metninde de Yargıtay’ın temyiz incelemesi yapmaksızın dosyayı ek karar vermek üzere hükmü veren mahkemeye göndereceği açıkça ifade edilmiştir ${ }^{293}$. Bu kapsamda, ek karar verilmek üzere dosya, Yargitay tarafından hükmü veren mahkemeye gönderilecektir ${ }^{294}$ (HMK m. 310/f. 3).

HMK m. 310/f. 3 hükmünde gerçekleştirilen değişikliğin yerinde olup olmadığı hususu doktrinde tartışma konusu yapılabilecektir. Bu kapsamda, doktrinde ileri sürülen bir görüşe göre, kanun koyucunun öngördüğü bu düzenlemenin gereksiz ve bilinenin kanuna geçirilmesinden ibarettir ${ }^{295}$. Kanaatimizce, temyiz aşamasında davadan feragat edilmesi konusunda 7251 sayılı Kanunla, uygulamada var olan durum 6100 sayılı Hukuk Muhakemeleri Kanunu’na eklenmişse de getirilen düzenlemenin tamamıla bilinen durumun kanuna geçirilmesinden ibaret olduğunun ifade edilmesi yerinde olmaz ${ }^{296}$. Zira, Yargıtay’n iç̧tihatlarında ifade edilen şekilde davadan feragat üzerine bozma kararı verilerek hükmün ilk derece mahkemesine göndermesi, bu konuda bir bozma sebebi olmadığ göz önünde bulundurulduğunda usul yasalarına aykırılık teşkil etmekteydi. Bu sebeple, 7251 sayılı Kanun değişikliğiyle birlikte, Yargıtay’ın temyiz incelemesi gerçekleştirmeksizin (böylelikle bozma kararı vermeden) dosyayı ek karar almak üzere hükmü veren mahkemeye göndermesi uygulamada isabetli olmayan durumun düzeltilmesi bakımından yerinde olmuştur. Ayrıca, HMK m. 310/f.

289 Öztek, Taşpınar Ayvaz ve Kale (n 32) 138-139; Hakan Pekcanıtez, Oğuz Atalay ve Muhammet Özekes, 'Hukuk Muhakemeleri Kanunu ile Bazı Kanunlarda Değişiklik Yapılmasına Dair Kanun Teklifinin (2020) Değerlendirilmesi', LexperaBlog, (30.03.2020) <https://blog.lexpera.com.tr/hmk-ile-bazi-kanunlarda-degisiklik-yapilmasina-dair-kanunteklifinin-2020-degerlendirilmesi/> (Son Erişim Tarihi: 29.07.2020).

290 Yarg. 8. HD, 19.1.2015, E. 2014/20310, K. 2015/1022 "HMK'nun 310. maddesine göre davadan feragat, hüküm kesinleşinceye kadar her zaman yapılabilir. 311. maddesinde ise feragat kesin hüküm gibi hukuki sonuç doğurur. Karar kesinleşinceye kadar davadan feragatın mümkün olduğuna, Mahkemece, bir karar verilip, davadan el çekildikten sonra temyiz aşamasında davacı vekili tarafindan davadan feragat edildiğine ve bu aşamada feragat hakkında karar verme yetkisi yerel mahkemeye ait bulunduğına göre, davacı vekilinin davadan feragat beyan hakkında bir karar verilmek üzere hükmün bozulması gerekmektedir." (Lexpera). Yargıtay’n aynı hükmü içeren bir başka kararı için bkz.: Yarg. 8. HD, 12.12.2017, E. 2017/14239, K. 2017/16613 (Lexpera).

291 Öztek, Taşpınar Ayvaz ve Kale (n 32) 139.

292 Bkz.: HMK m. 310/f. 3.

293 Öztek, Taşpınar Ayvaz ve Kale (n 32) 139

294 Arslan, Yllmaz, Taşpınar-Ayvaz ve Hanağası, (n 13) 566; Öztek, Taşpınar Ayvaz ve Kale (n 32) 138; Tanrıver, Medenî Usûl C. I (n 16) 1047; Karslı (n 1) 374; Budak ve Karaaslan (n 1) N. 13, s. 322; Atalı, Ermenek ve Erdoğan (n 1) 575; Görgün, Börü, Toraman ve Kodakoğlu (n 6) 598.

295 Hakan Pekcanıtez, Oğuz Atalay ve Muhammet Özekes, 'Hukuk Muhakemeleri Kanunu ile Bazı Kanunlarda Değişiklik Yapılmasına Dair Kanun Teklifinin (2020) Değerlendirilmesi', LexperaBlog, (30.03.2020) <https://blog.lexpera.com.tr/ hmk-ile-bazi-kanunlarda-degisiklik-yapilmasina-dair-kanun-teklifinin-2020-degerlendirilmesi/> (Son Erişim Tarihi: 29.07.2020).

296 Öztek, Taşpınar Ayvaz ve Kale (n 32) 139. 
3 hükmünde öngörülen düzenleme ile Yargıtay'ı yerleşik uygulamasındaki gibi bozma kararı verilmesinin öngörülmemesi, usul ekonomisi bakımından da uygun bir yöntem olması sebebiyle isabetlidir ${ }^{297}$.

\section{DEĞERLENDIRME VE SONUÇ}

Davadan feragat davaya son veren usul işlemlerinden birisidir. Bunun doğal bir sonucu olarak, davacının davadan feragat edebilmesi için açılmış ve görülmekte olan bir davanın bulunması gerekmektedir. 6100 sayılı Hukuk Muhakemeleri Kanunu’nda getirilen açık düzenleme ile davadan feragatin hükmün kesinleşinceye kadar her zaman yapılabileceği ifade edilmektedir. Buna göre, kural olarak, ilk derece mahkemesi tarafından yargılamanın devam ettiği bir esnada, açtığı davaya devam etmek istemeyen davacı, tasarruf ilkesinin (HMK m. 24) doğal bir sonucu olarak davasından feragat edebilir. Böylelikle, davacının davasından feragat etmesi üzerine, ilk derece mahkemesince devam eden yargılama sona erecektir. HMK m. 310'da davadan feragatin hükmün kesinleşmesinden önce yapılabileceği ifade edildiğinden davadan feragat, ilk derece mahkemesince hükmün verilmesinden sonra ve fakat hükmün kesinleşmesinden önce kanun yollarına müracaat süresi içerisinde ve kanun yolları aşamalarında da gerçekleştirilebilir. Bununla beraber, hükmün şekli anlamda kesinleşmesinden sonra ortada derdest bir dava bulunmayacağ için, bu aşamada davaya son veren taraf usuli işlemlerinden olan feragat yoluna gidilebilmesi söz konusu olmaz.

Davadan feragat, hükmün kesinleşmesine kadar her zaman yapılabileceği için, sadece ilk derece mahkemesindeki yargılamanın devamı boyunca değil; aynı zamanda hükmün şekli anlamda kesinleşmesine kadar gerçekleştirilebilir. Bu sebeple, ilk derece mahkemesince hüküm verildikten sonra ve fakat kanun yollarına henüz müracaat edilmediği ya da dosyanın kanun yollarında - istinaf veya temyiz - incelendiği bir aşamada davadan feragat edilebilir.

Yargılamanın, ilk derece mahkemesince gerçekleştirildiği bir esnada davadan feragat edilmesi durumunda, ilk derece mahkemesince davanın feragat işlemiyle sona erdiği ifade edilerek usule ilişkin bir kararla yargılamaya son verilmesi gerekir. Bununla birlikte, ilk derece mahkemesince hüküm verildikten sonra hükmün kanun yollarına müracaat süresi içerisindeyken veya kanun yollarına götürülmesinden sonra davadan feragat edilmesi durumunda hangi merci tarafından karar verileceği konusunda kanunlarımızda herhangi bir açıklık söz konusu değildi. Bununla birlikte, hükmün verilmesinden sonra kanun yolları süresi içerisinde veya kanun yolları aşamasında davadan feragat hakkında karar verecek olan merci ve vereceği karar hakkında, Yargıtay’ın istikrar kazanan kararları ile şekillenen yerleşik bir uygulaması söz konusuydu.

Diğer taraftan, yakın zamanda kabul edilen yönetmeliklerde ilk derece mahkemesince hükmün verilmesinden sonra, hüküm kesinleşinceye kadar ki aşamada davadan feragat edilmesi üzerine, hangi merci tarafından ne şekilde işlem yapılacağını düzenleyen hükümlere yer verildiğini görmekteyiz. Bu konuda kabul edilen ilk düzenleme, 3 Nisan 2012 tarihinde 28253 sayılı Resmî Gazetede 
yayımlanan Hukuk Muhakemeleri Kanunu Yönetmeliği’nin 57’nci maddesinde getirilmekteydi. Hukuk Muhakemeleri Kanunu Yönetmeliği’nin yürürlükten kaldırılmasından sonra 5 Ağustos 2015 tarihli 29437 sayılı Resmî Gazete'de yayınlanan Bölge Adliye ve Adli Yargı İlk Derece Mahkemeleri ile Cumhuriyet Başsavcılıkları İdari ve Yazı İşleri Hizmetlerinin Yürütülmesine Dair Yönetmeliğin yürürlüğe girmesiyle birlikte 215 'inci maddesinde öngörülen düzenleme uygulamaya konulmuştur. Kanun koyucu, yeni Yönetmelik ile kabul edilen 215'inci madde hükmünde, yürürlükten kaldırılan Hukuk Muhakemeleri Kanunu Yönetmeliği’nin 57'nci maddesinde yer alan esaslarla birebir aynı düzenlemeleri getirmiştir.

Yönetmeliğin 215’inci maddesinde (eski HMK Yönetmeliği m. 57), kanun yollarına müracaat edilmeden veya kanun yolarına müracaat edilmekle birlikte dosyanın Yüksek mahkemeye ulaşmasından önce davadan feragat edilmesi durumunda, bu hususta mahkemece bir "ek karar" verileceği düzenlenmektedir. Bununla birlikte, hükmün verilmesinden sonra ve fakat kanun yolu incelemesinin gerçekleştirilmesinden önceki bir aşamada davadan feragat edilmesi durumunda Yönetmelik (HMK Yönetmeliği m. 57; Yazı İşleri Yönetmeliği m. 215) ile getirilen düzenlemeden önce, bu konuda var olan boşluk Yargıtay kararları ile şekillenen yerleşik uygulama ile giderilmekteydi.

Yargitay'ın yerleşik uygulamasında, ilk derece mahkemesince karar verildikten sonra dosyadan el çekileceği için, davadan feragat edilmesi üzerine hükmü veren mahkemece tekrardan karar verilemeyeceği içtihat edilmekteydi. Bu durumda, ilk derece mahkemesince karar verildikten sonra kanun yoluna müracaat süresi içerisindeyken ya da kanun yoluna müracaat edilmekle birlikte, dosyanın henüz yüksek mahkemece incelenmediği bir aşamada davadan feragat edilmesi üzerine feragat dilekçesinin temyiz talebi olarak kabul edileceği ifade edilmekteydi. Böylelikle, feragat edilen dosyanın Yargitay tarafından feragat sebebiyle bozulmasından sonra kararı veren ilk derece mahkemesine gönderileceği ve feragat sebebiyle yargılamaya son verileceği ifade edilmekteydi.

Doktrinde, Yargıtay’n yerleşik uygulamasını yerinde olmadığı belirtilerek bu konuda eleştiriler getirilmiştir. Kanaatimizce de Yargıtay kararlarına yansıyan uygulama eleştirilebilecek yönlere sahipti. Zira, öncelikle, Yargıtay’ın yerleşik içtihatlarında belirtilen şekilde yerel mahkemece karar verildikten sonra kanun yoluna müracaat edilmeden önce davacının yönelttiği feragat dilekçesinin temyiz talebi olarak kabul edilmesi isabetli bir uygulama değildi. Zira, hukuk davalarında, hüküm verildikten sonra davadan feragatin Yargitay tarafından bozma sebebi olarak kabul edilmesi usul yasalarına aykırılık teşkil etmekteydi. Ayrıca, feragat sebebiyle dava dosyasının kanun yolu mahkemesine gönderilerek sonrasında onun bozması üzerine ilk derece mahkemesine tekrardan intikal etmesi ve bunun üzerine ilk derece mahkemesinin feragat sebebiyle karar vermesi ciddi bir zaman ve emek kaybı teşkil edecekteydi. Bu sebeple, Yargıtay tarafından benimsenen uygulama, aynı zamanda usul ekonomisi ilkesine (HMK m. 24) de aykırı nitelikteydi.

Yargıtay kararlarında ifade edilen ve doktrinde eleştirilen feragat üzerine dosyanın Yargıtay’a gönderilerek feragat sebebiyle bozulmasından sonra ilk derece mahkemesince yargilamanın feragat sebebiyle bozulduğuna ilişkin uygulama ile Yönetmeliklerle (HMK Yönetmeliği m. 57; Yazı İşleri Yönetmeliği m. 215) getirilen ilk derece mahkemesince ek karar alınması hususunu 
düzenleyen kural birbirlerinden farklılık arz etmekteydi. Bu doğrultuda, Hukuk Muhakemeleri Kanunu Yönetmeliği’nin 57’nci maddesi ile yeni bir düzenleme getirilmesi üzerine Yargitay, yönetmelik hükmünün uygulanmasını yerinde olmadığını ifade eden kararlar ortaya koymaktaydı. Diğer bir deyişle, bu hususta yerleşik uygulamanın devam etmesi gerektiği yönünde kararlar vermekteydi. Bununla birlikte, HMK Yönetmeliği m. 57 ile birebir aynı düzenlemeyi getiren Yazı İşleri Yönetmeliği’nin 215'nci maddesinin yürürlüğe girmesinden sonra yakın tarihli kararlarında, yerleşik uygulamasından farklı olarak ilk derece mahkemesi tarafından verilen hükme karşı temyiz kanun yoluna müracaat edilmediği ya da dosyanın temyiz edilmekle birlikte incelemeyi gerçekleştirecek olan mahkemeye gönderilmediği bir aşamada davadan feragat edilmesi üzerine Yazı İşleri Yönetmeliği’nin 215’nci maddesinde öngörüldüğü şekilde, ilk derece mahkemesince ek karar verileceğine hükmedildiğini görmekteyiz. Yargıtay tarafından eskiden beri süregelen uygulamanın devam etmesi gerektiği konusunda 1srar edilmesi kanaatimizce isabetli değildi. Bu sebeple, Yargıtay tarafından son zamanlarda ortaya konulan kararlarda Yazı İşleri Yönetmeliğìnin 215’inci maddesindeki uygulamaya riayet edilerek, dosyanın ilk derece mahkemesine gönderilmesinin gerektiğinin içtihat edilmesi yerinde olmuştur. Buna karşılık, Yazı İşleri Yönetmeliği’nin 215’inci maddesinde, ek karar alınmasını öngören düzenlemeye yer verilmesi bahsi geçen düzenlemenin kanuni bir zemine dayanmaması sebebiyle doktrinde eleştirilmekteydi.

7251 sayılı HMK değişikliği ile birlikte, davadan feragatin zamanı hakkında Hukuk Muhakemeleri Kanunu'nun 310'uncu maddesinde açıkça düzenleme getirilerek uygulamada var olan durum kanun hükmü haline getirilmiştir. Yeni getirilen HMK m. 310/f. 2 hükmüne göre, davadan feragat, hükmün verilmesinden sonra gerçekleştirilmişse, yargılamanın taraflarınca kanun yoluna müracaat edilmiş olsa bile, dosyanın kanun yoluna gönderilmeyeceği ve ilk derece mahkemesi veya bölge adliye mahkemesince feragat doğrultusunda ek karar verileceği hükme bağlanmıştır. 7251 sayılı Kanun ile getirilen bu düzenleme sayesinde, feragat edilen dava dosyasının kanun yolu incelemesine gönderilmeksizin nihayete erdirilmesi sağlanarak emek ve zaman kaybının yaşanmasının önüne geçilmiştir. Aynı zamanda bu şekilde bir düzenlemelerin getirilmesiyle usul ekonomisi ilkesine riayet edilmesi sağlanmıştır. 7251 sayılı Kanunla HMK m. 310/f. 2 hükmünde gerçekleştirilen değişikliklerin esasen Yazı İşleri Yönetmeliği m. 215 ile Yargıtay kararlarıyla şekillenen uygulamanın kanuna yansitılması olduğu ifade edilebilecektir. Bununla birlikte, HMK m. 310 hükmünde kabul edilen değişikliklerin tamamen bilinenin ortaya konulmasından ibaret olduğunu söylemek isabetli olmayacaktır. Zira, HMK m. 310/f. 2'de, Yazı İşleri Yönetmeliği m. 215’te öngörülen düzenlemeye yer verilmesi sayesinde, yönetmelikle getirilen düzenlemelere kanuni bir dayanak sağlanmıştır. $\mathrm{Bu}$ sebeple, kanun yapma tekniği bakımından önemli bir eksikliğin giderilmesi söz konusu olmuştur.

7251 sayılı HMK değişikliği ile temyiz aşamasında davadan feragat konusunda da kanun koyucu tarafından düzenleme getirilmiştir. Buna göre, HMK m. 310 hükmüne eklenen 3’üncü fikra ile, temyiz kanun yolunda davadan feragat edilmesi söz konusu olduğunda, Yargıtay tarafından temyiz incelenmesi gerçekleştirilmeksizin dosyanın feragat hakkında ek karar verilmek üzere hükmü veren mahkemeye gönderilmesinin gerektiği hükme bağlanmıştır. HMK m. 310/f. 3 ile Yargıtay’n istikrara kazanan kararlarında olduğu gibi davadan feragat edilmesi üzerine hükmün bozularak onu veren mahkemeye göndermesi yönündeki uygulamasından vazgeçilmiştir. Bunun yerine, temyiz kanun 
yolundaki bir dosya hakkında feragat iradesinin ileri sürülmesi üzerine, ek karar verilmesi için hükmün verildiği mahkemeye gönderileceği kabul edilmiştir. HMK 310/f. 3 hükmüyle, her ne kadar yönetmelik ve Yargıtay kararlarıyla şekillenen uygulama ile paralel bir düzenleme getirilmişse de, kanun maddesinde Yargıtay tarafından temyiz incelemesine tabi tutulamayacağı ve bozma konusu yapılamayacağının açıkça öngörülmesi önemli bir aksaklığın giderilmesi bakımından isabetli olmuştur.

Genel olarak değerlendirildiğinde 7251 sayılı Kanunla getirilen düzenlemelerde, yönetmelikte öngörülen hükümlere kanuni bir zemin kazandırılmış olması ve usul ekonomisi ilkesinin de

gözetilmiş olması HMK m. 310 hükmünde gerçekleştirilen değişikliklerin yerindeliğini ortaya koymaktadır.

\section{KAYNAKÇA}

Akil C, İstinaf Kavramı (1. Bası, Yetkin 2010).

Akkaya T, Medeni Usul Hukukunda İstinaf (1. Bası, Yetkin 2009).

Akyol Aslan L, Medeni Usul Hukukunda Davadan Feragat (1. Bas1, Yetkin 2011).

Alangoya Y, Yıldırım MK ve Deren-Yıldırım N, Medeni Usul Hukuku Esasları (7. Bası, Beta 2009) (Esaslar).

Alangoya Y, Yıldırım MK ve Deren-Yıldırım N, Hukuk Muhakemeleri Kanunu Tasarısı Değerlendirme ve Önerileri (İstanbul Barosu Yayınları 2006) (Tasari).

Ansay, SŞ, Hukuk Yargılama Usulleri (7. Bası, Ankara Üniversitesi Hukuk Fakültesi Yayınları 1960).

Arslan R, Yılmaz E, Taşpınar-Ayvaz S ve Hanağası E, Medenî Usul Hukuku (Güncellenmiş ve 7251 sayılı Kanun Değişiklikleri İşlenmiş 6. Bası, Yetkin 2020).

Aslan Kudret, Medeni Usul Hukukunda Davadan Feragat (Yayımlanmamış Yüksek Lisans Tezi), Ankara, 1999.

Atalı M, Ermenek İ ve Erdoğan E, Medeni Usul Hukuku Ders Kitabı (3. Bası, Yetkin 2020).

Atalı M, Pekcanttez Usul Medeni Usul Hukuku, C. III (15. Bası, On İki Levha 2017).

Beck'scher Online-Kommentar ZPO, (Herausgegeben von Volkert Vorwerk und Christian Wolf) (36. Edition, Stand: 01.03.2020, Verlag C.H. BECK München 2020) (BeckOK ZPO/Elzer, ZPO).

Belgesay MR, Hukuk Usulü Muhakemeleri Kanunu Şerhi I Teoriler (3. Bası, Duygu Matbaası 1948).

Berki Ş., Hukuk Muhakemeleri Usulü (Ege 1959).

Berkin NM, Tatbikatçılara Medeni Usul Hukuku Rehberi (Filiz Kitabevi 1982).

Bilge N, Medeni Yargllama Hukuku Dersleri (Sevinç Matbaası 1967).

Bilge N ve Önen E, Medeni Yargılama Hukuku Dersleri (3. Bs, Sevinç Matbaası 1967).

Budak AC ve Karaaslan V, Medeni Usul Hukuku (4. Bas1, Adalet 2020).

Budak AC ve Karaaslan V, Medeni Usul Hukuku (3. Bas1, Adalet 2020).

Çenberci M, 'Hukuk Davalarında Kesin Hüküm' (1964) 9-12, Adalet Dergisi, 1137-1177.

Ercan İ ve Özbay İ, 'Medeni Usul Hukukunda Kanun Yollarından Feragat' (2006) X (3-4) Erzincan Üniversitesi Hukuk Fakültesi Dergisi 433-458.

Erdemir İ, Hukuk Usulü Muhakemeleri Kanunu Şerhi (2. Bası, Cilt 1-2 Sim Matbaacılık 1988).

Erdönmez G, Pekcanıtez Usul Medeni Usul Hukuku, C. I (15. Bası, On İki Levha, 2017).

Gençcan, ÖU: 6100 Sayıl Hukuk Muhakemeleri Kanunu Yorumu, Bilimsel Açıklama-Son İçtihatlar (Yetkin 2013). 
Görgün ŞL, Börü L, Toraman B ve Kodakoğlu M, Medeni Usul Hukuku (28.07.2020 tarih ve 7251 sayılı Kanunla Değiştirilmiş, Güncellenmiş, Yetkin 2020).

İnal N, Örnek Karar Dilekçelerle Açıklamalı Hukuk Yargılama Usulü Yasası (Yeni Yasa, 2012).

Karafakih İH, Hukuk Muhakemeleri Usulü Esasları (Ankara Üniversitesi Siyasal Bilgiler Fakültesi Yayınları, Ankara 1952).

Karahacıoğlu AH ve Parlar A, 6100 Sayılı Hukuk Muhakemeleri Kanunu Şerhi (Bilge, 2014).

Karslı A, Medeni Muhakeme Hukuku (Yenilenmiş ve Gözden Geçirilmiş 5. Bası, Filiz 2020).

Koç E ve Konuralp CS, Adli Yargı İlk Derece Mahkemeleri ve Bölge Adliye Mahkemesi Kalem Mevzuatı (Sümer, 2017).

Kuru B, Medeni Usul Hukuku El Kitabı Cilt 2 (Yetkin 2020) (El Kitabı C. 2).

Kuru B, Hukuk Muhakemeleri Usulü, C. IV (6. Bas1, Demir-Demir 2001) (C. IV).

Kuru B, Hukuk Muhakemeleri Usulü, C. V (6. Bası, Demir-Demir 2001) (C. V).

Kuru B, Medeni Usul Hukuku Ders Kitabı (1. Bası, Legal 2015) (Ders Kitabı).

Kuru B, Arslan R ve Yılmaz E, Medeni Usul Hukuku Ders Kitabı 6100 sayılı HMK’na Göre Yeniden Yazılmış (Tıpkı Basim) (24. Bası, Yetkin 2013) (Medeni Usul).

Kuru B, Hukuk Muhakemeleri Usulü El Kitabı (1. Bası, Alfa 1995) (El Kitabı).

Kuru B, İstinaf Sistemine Göre Yazılmış Medeni Usul Hukuku Ders Kitabı (1. Bası, Yetkin 2017) (İstinaf Sistemine Göre).

Kuru B ve Aydın B, İstinaf Sistemine Göre Yazılmış Medenî Usul Hukuku Ders Kitabı (7251 sayılı Kanun Değişiklikleri İşlenmiş 4. Baskı, Yetkin, 2020).

Meriç N, Medeni Yargılama Hukukunda Tasarruf İlkesi (Hukuk Muhakemeleri Kanunu Çerçevesinde), (Yetkin, 2011).

Musielak HJ, Kommentar zur Zivilprozessordnung mit Gerichtsverfassungsgesetz (8., Neubearbeitete Auflage, Verlag Franz Vahlen München, 2011).

Musielak HJ und Voit W, Zivilprozessordnung: ZPO mit Gerichtsverfassungsgesetz (17., neubearbeitete Auflage, Verlag Franz Vahlen, 2020).

Musielak HJ, Münchener Kommentar zur Zivilprozessordnung Bd. 1: S\$ 1-354, Wolfgang Krüger (Hrsg.) (6. Auflage, C.H.Beck 2020) (MüKoZPO/Musielak, ZPO \$ 306).

Muşul T, Medeni Usul Hukuku (6100 sayılı Hukuk Muhakemeleri Kanunu Esas Alınarak Hazırlanmış 3. Bası, Adalet 2012).

Önder A 'Hukuk Davalarında Hüküm Lahik Olduktan Sonra Davadan Feragat Temyiz Mahkemesince Bozma Sebebi İttihaz Olunabilir Mi?' (1942) 7 AD 799-810.

Önen E, 'Feragat ve Kabul Kesin Hüküm Teşkil Etmez' (1976) 1 ABD 26-39 (Feragat).

Önen E, Medeni Yargılama Hukuku (Sevinç Matbaası, 1979) (Medeni Yargılama).

Öztek S, Taşpınar Ayvaz S ve Kale S, 'Hukuk Muhakemeleri Kanunu ile Bazı Kanunlarda Değişiklik Yapılması Hakkında 20 Mart 2020 Tarihli Kanun Teklifi’ne İlişkin Bazı Açıklamalar ve Kanun Teklifinin Değerlendirilmesi’ (2020) Temmuz-Ağustos 33(149), Türkiye Barolar Birliği Dergisi, 77-151

Pekcanıtez H, Atalay O ve Özekes M, 'Hukuk Muhakemeleri Kanunu ile Bazı Kanunlarda Değişiklik Yapılmasına Dair Kanun Teklifinin (2020) Değerlendirilmesi', LexperaBlog, (30.03.2020) <https://blog.lexpera.com. tr/hmk-ile-bazi-kanunlarda-degisiklik-yapilmasina-dair-kanun-teklifinin-2020-degerlendirilmesi/> (Son Erişim Tarihi: 29.07.2020).

Pekcanıtez, H, Atalay O ve Özekes M, Medeni Usul Hukuku Ders Kitabı (7035, 7101 ve 7155 Sayılı Kanunlarla Yapılan Değişiklikler Nazara Alınarak Gözden Geçirilmiş 8. Bası, On İki Levha, 2020). 
Postacıoğlu, İE, Medeni Usul Hukuku Dersleri (1911 Sayılı Kanun’a Göre Yazılmış 6. Bası, Sulhi Garan 1975). Postacığlu İE ‘Şarta Muallâk Hükümler' (1941) 2 Adalet Dergisi 112-122 (Şarta Muallak Hükümler).

Postacıoğlu İE ve Altay S, Medeni Usul Hukuku Dersleri (Güncelleştirilmiş, Genişletilmiş 8. Bs, Vedat 2020).

Rosenberg L, Schawb KH und Gottwald P, Zivilprozessrecht (17., neu bearbeitete Auflage, München, Verlag C. H. Beck oHG, München, 2010).

Saenger I, Zivilprozessordnung: ZPO (Familienverfahren, Gerichtsverfassung, Europaische Verfahrensrecht), Handkommentar, (8. Auflage, Nomos, 2019).

Sanıvar, HD, Türk Medeni Yargılama Hukukunda Davadan Feragat (Marmara Üniversitesi Sosyal Bilimler Enstitüsü, Yayımlanmamış Yüksek Lisans Tezi, 2017).

Soner, LF, 'Feragat, Kabul ve Sulhe Dair Bazı Sorunlar' (1977) 3 ABD 439-448.

Sümer N, 'Şartlı Feragata İlişskin Danıştay Kararlarının Düşündürdükleri' (2018) 2 Galatasaray Üniversitesi Hukuk Fakültesi Dergisi 267-284.

Tanrıver S, Medenî Usûl Hukuku, C. I, Temel Kavramlar ve İlk Derece Yargılaması (Tümüyle Gözden Geçirilmiş, Yenilenmiş ve Genişletilmiş 2. Bası, Yetkin 2018) (Medenî Usûl C. I).

Süha Tanrıver, 'Şarta Bağlı Hüküm Kavramı ve Verilip Verilemeyeceği Sorunu' (1988) 19 (4) Banka ve Ticaret Hukuku Dergisi 45-50 (Şarta Bağlı Hüküm).

Taşpınar Ayvaz S, 'HMK Yönetmeliği ile Usul hükmü Getirilemez', 2013/3 Güncel Hukuk Dergisi 552-555.

Ulukapı Ö, Medenî Usûl Hukuku (3. Bası, Mimoza 2015).

Umar B, Hukuk Muhakemeleri Kanunu Şerhi (Yargıçve Avukatlar İçin HMK Uygulamasında Karşılaşılacak Soru ve Sorunların Türk ve Neuchâtel Bilimsel ve Yargısal İçtihatları Işı̆̆ında Yanıtları ve Çözümleri) (2. Bası, Yetkin 2014).

Üstündağ S, Medeni Yargılama Hukuku, C. I-II (Gözden Geçirilmiş ve Yenilenmiş 7. Bası, Nesil 2000).

Yavuz N, 'Hukuk Davalarında Feragat ve Yargitay 8. Hukuk Dairesinin En Son Bir Kararı Üzerine Bazı Düşünceler' 1977 (6) Ankara Barosu Dergisi 1019-1025.

Yılmaz E, Hukuk Muhakemeleri Kanunu Şerhi (2. Bası, Yetkin 2013) (Şerh).

Yllmaz E, İstinaf (2. Bs., İstanbul, Yetkin 2005) (İstinaf).

\section{ELEKTRONIKK KAYNAKLAR}

https://beck-online.beck.de/Home

https://www.mevzuat.gov.tr/MevzuatMetin/1.5.6100.pdf

https://www.mevzuat.gov.tr/MevzuatMetin/5.3.1086.pdf

https://www.barobirlik.org.tr/Haberler/hukuk-muhakemeleri-kanunu-yonetmeligi-12642.

https://www.hukukmedeniyeti.org/karar/275831/yargitay-8-hukuk-dairesi-e-2016-10528-k-2017$2702 /$ ? =list\&aranan=davadan\%20feragat

www.hukukmedeniyeti.org

http://www.e-uyar.com/

https://www.lexpera.com.tr/

https://legal.com.tr/

http://www.hukukturk.com/sonuc.aspx?q=k\&p=1922

http://www.adalet.gov.tr/duyurular/2015/agustos/yonetmelik.html

http://www.kazanci.com/kho2/ibb/giris.html

https://dejure.org/gesetze/ZPO/306.html 